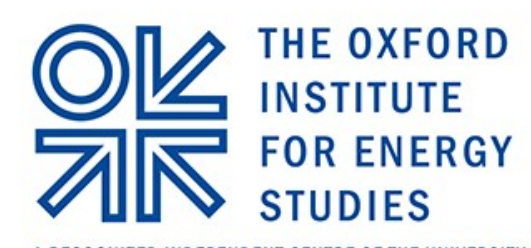

A RECOGNIZED INDEPENDENT CENTRE OF THE UNIVERSITY OF OXFORD

February 2014

\title{
Natural Gas in the Turkish Domestic Energy Market:
}

Policies and Challenges

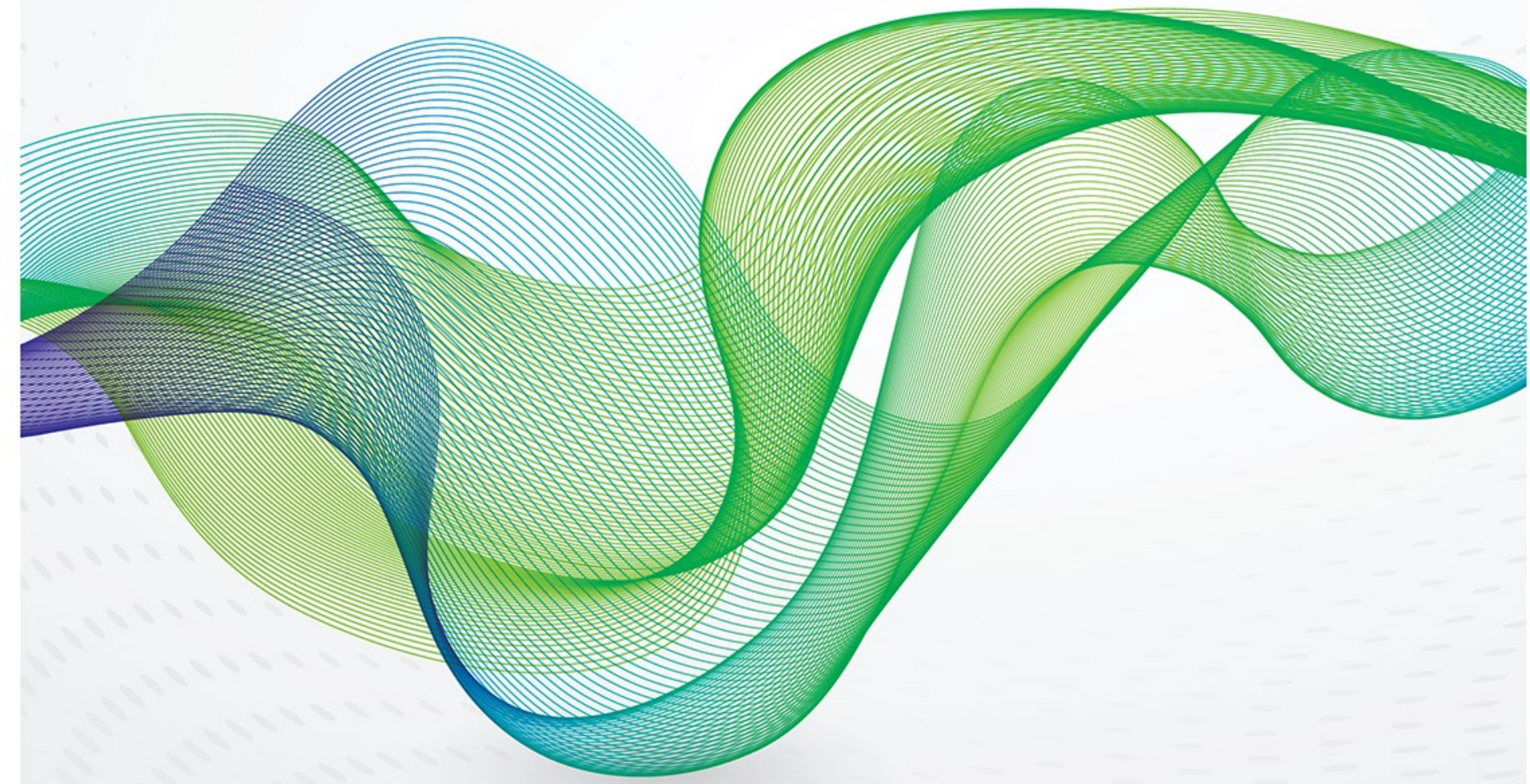

Gulmira Rzayeva* 

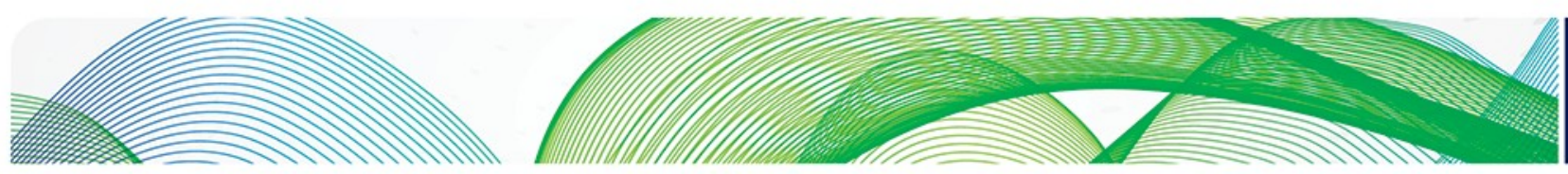

\section{O는}

The contents of this paper are the authors' sole responsibility. They do not necessarily represent the views of the Oxford Institute for Energy Studies or any of its members.

\section{Copyright $\odot 2014$}

Oxford Institute for Energy Studies

(Registered Charity, No. 286084)

This publication may be reproduced in part for educational or non-profit purposes without special permission from the copyright holder, provided acknowledgment of the source is made. No use of this publication may be made for resale or for any other commercial purpose whatsoever without prior permission in writing from the Oxford Institute for Energy Studies.

ISBN 978-1-907555-93-0 

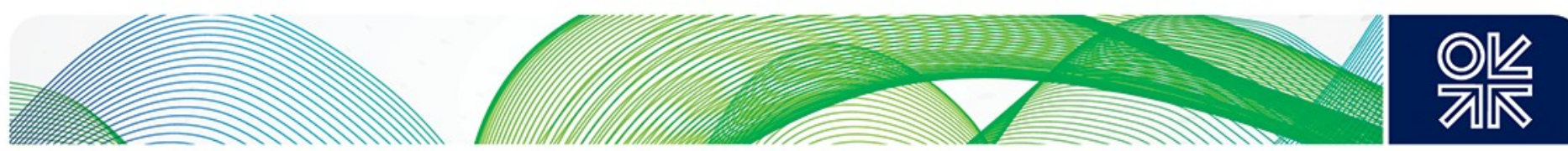

\section{Acknowledgements}

My greatest thanks are to my colleagues at the Institute Howard Rogers and Simon Pirani who invited me to the Institute and gave me a chance to conduct a research on this important topic. I thank them for reviewing the paper and for their valuable comments.

My sincere thanks are due to Fatih Cerit from EMRA who constantly provided me with the data and figures. A big thank you to Ilham Akbarov for his helpful comments and insights. A big thank-you to John Elkins for his careful review of the paper and editorial corrections.

My great thanks are to my director at the Center for Strategic Studies Dr. Farhad Mammadov, who supported the project from the beginning. My thanks also to Kate Teasdale for taking care of the publication of this paper in electronic and hardcopy versions.

I cannot leave out the names of the people who I met and interviewed in Turkey, and who were so generous to spend hours of their valuable time sharing the features of the Turkish domestic natural gas market. Those people are: Fatih Baltaci, Eren Aksoy, Necdet Pamir, Cafer Eminoğlu, Turgay Günay, Reha Muratoğlu, Barış Şanslı, Savaş Yanık, Hakan Ünal, Abdulla Erdem, Ahmet Polatkan, Mehmet Ertürk, Banu Köymen and others. 

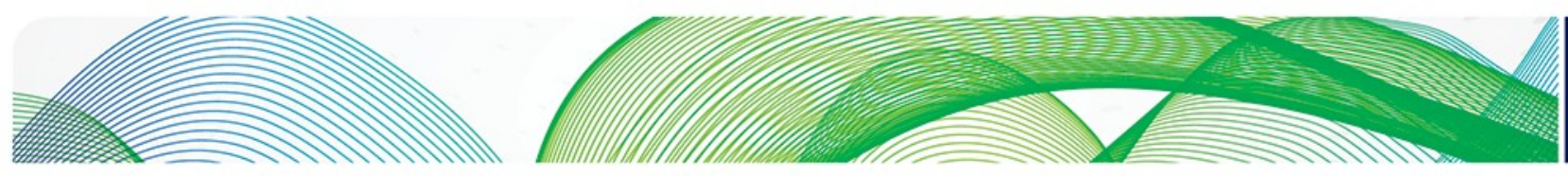

\title{
O픈
}

\begin{abstract}
About the author
Gulmira Rzayeva joined the Oxford Institute for Energy Studies as a Research Associate in 2013. She is a Senior Research Fellow at the Center for Strategic Studies (SAM) under the President of the Republic of Azerbaijan, and a Non-Resident Scholar at the Hazar Enstitutu (HASEN) in Istanbul. Her areas of expertise include the energy policy of Azerbaijan, Black Sea/Caspian region energy security and the Turkish domestic natural gas market. Ms Rzayeva has published articles on Azerbaijan's gas strategy and Azerbaijan's energy efficiency policy, and previously worked at the Moscow Carnegie Center as a Visiting Research Fellow and the Aleksanteri Institute of the University of Helsinki. She has a BA in International Relations from the Baku Slavic University and an MA in Global Affairs from the University of Buckingham, UK.
\end{abstract}



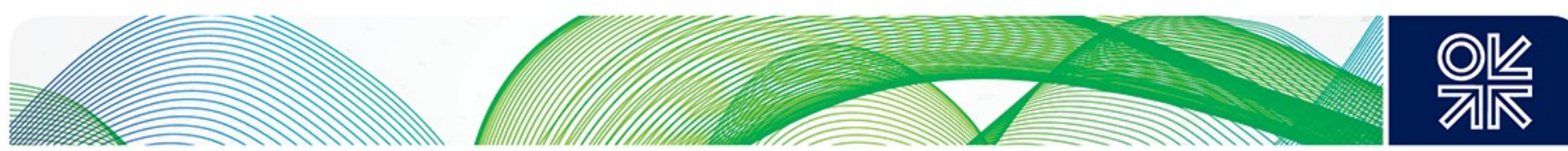

\section{Preface}

In gas circles Turkey, over the past 10 years or so, has been prominent in the various schemes to open a 'fourth corridor' of gas supply to the core European national gas markets. The grandeur of earlier visions has morphed into a pragmatic and initially more modest scheme to supply $10 \mathrm{Bcm} / \mathrm{yr}$ of gas beyond Turkey. With the Euro-centric political excitement around 'Nabucco' on the wane, European energy analysis and commentary has reverted to a focus on EU member states and the importance of the Turkish gas market in its own right has been overlooked.

In the post financial crisis period it should be noted that Turkey is the only significant European regional gas market to have shown strong growth post 2009 and its $45 \mathrm{Bcm}$ consumption in 2012 places it on a par with France. With domestic production contributing only $2 \%$ of its requirements Turkey imports pipeline gas from Russia, Azerbaijan and Iran and LNG from a number of supplier countries. Its likely continued rapid gas demand growth raises challenges not only of project logistics and timings but also, given its geographic location, those of a geopolitical dimension. In addition to its long held aspiration to become a regional gas transit 'bridge' between Central Asia, Iran and Iraq and Europe, Turkey is also in the process of liberalizing its gas market, with mixed success to date.

It seems a paradox in the gas world that the important, fast growing markets are also those with least data and analysis available. This has certainly been the case with Turkey. I am especially grateful to Gulmira Rzayeva for this paper, which is possibly the only comprehensive one in the English language on the Turkish gas market in recent times. Her dedication in conducting in-country research and interviews with key figures is admirable and in keeping with the record of the Gas Programme of insightful research on highly relevant market developments in this increasingly interconnected world of natural gas.

\section{Howard Rogers}

Oxford 2014 

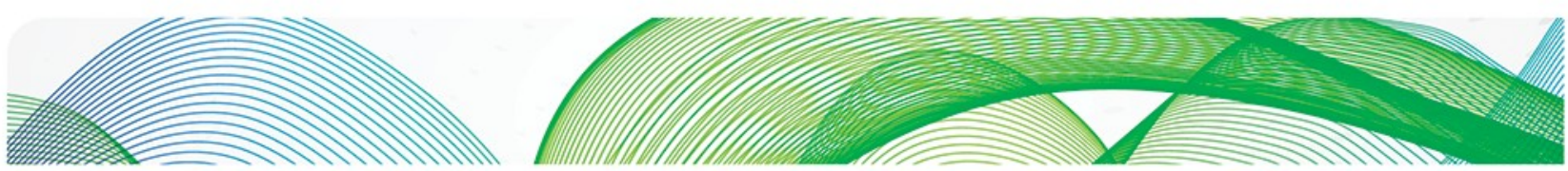
애잔

\section{Contents}

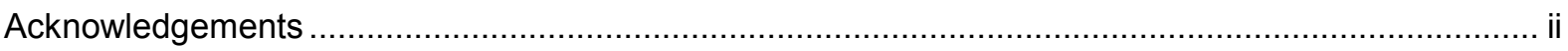

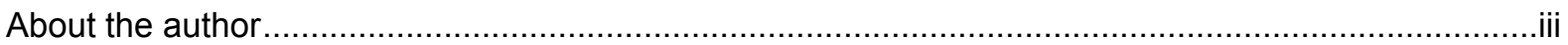

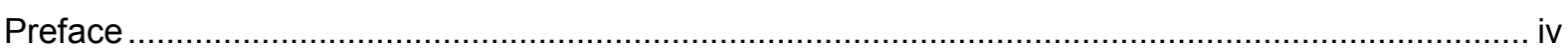

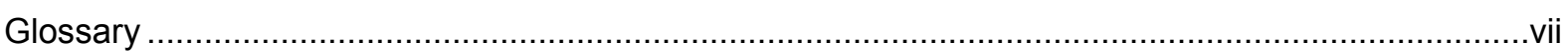

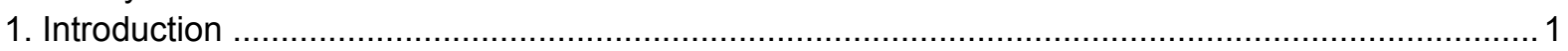

2. Key Dynamics Contributing to Demand and Supply Growth: Market Outlook ...............................5

2.1 Natural Gas in Power Generation and Installed Generation Capacity.................................. 10

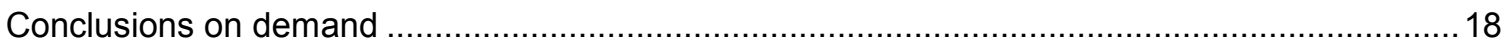

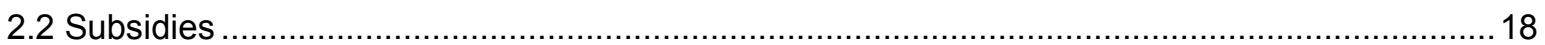

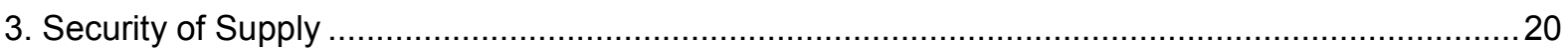

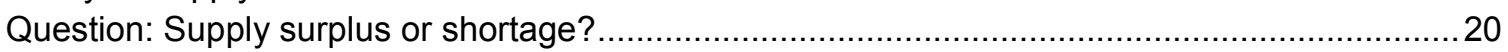

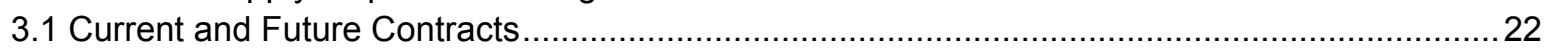

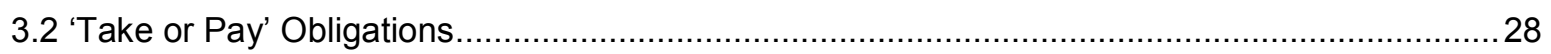

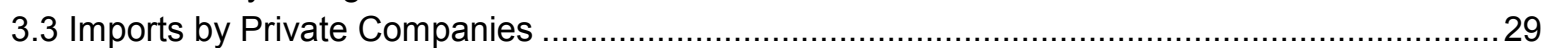

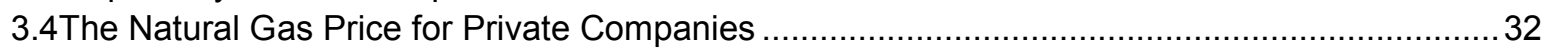

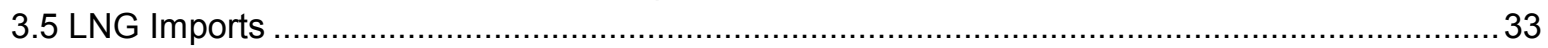

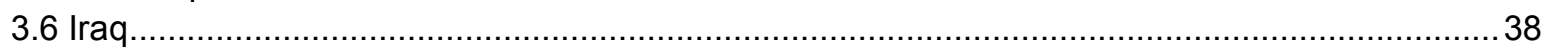

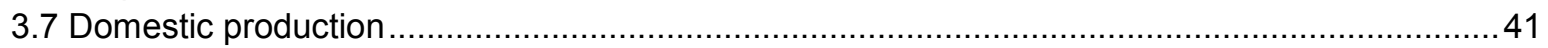

4. Development of Regulatory Framework: What Kind of Liberalization of the Domestic Natural Gas

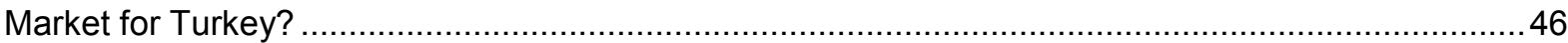

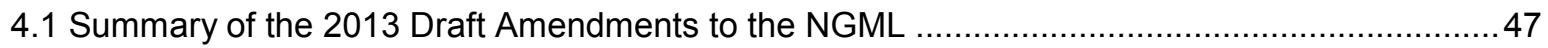

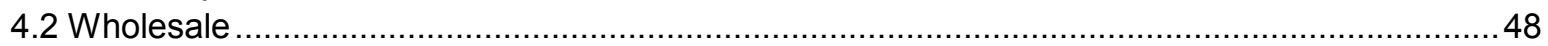

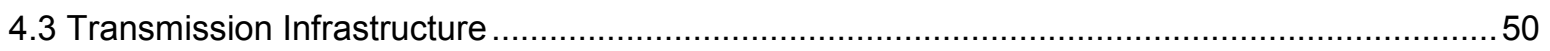

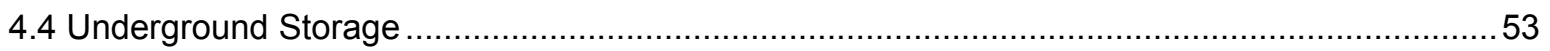

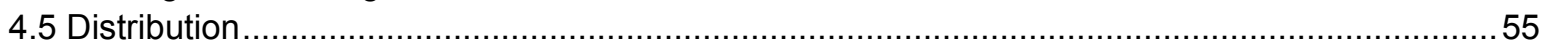

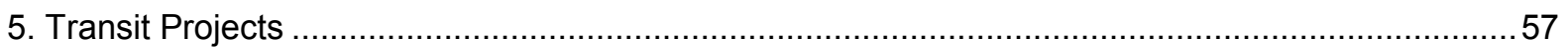

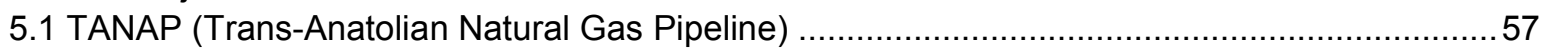

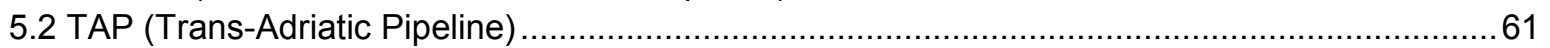

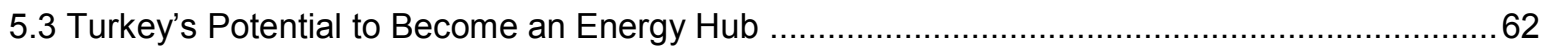

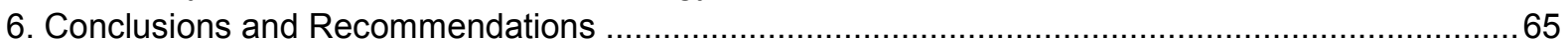

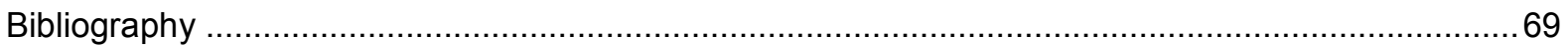

Figures

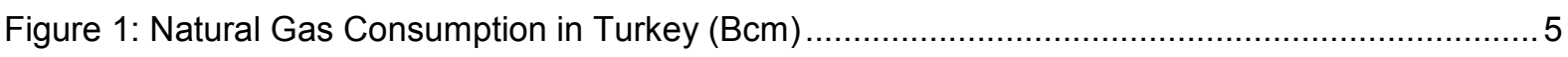

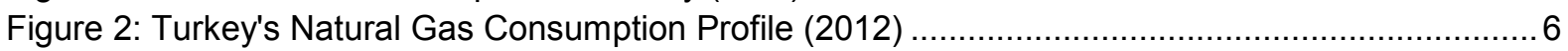

Figure 3: Annual Real GDP Growth (\%) Forecast in OECD Countries 2012-2017 ........................ 7

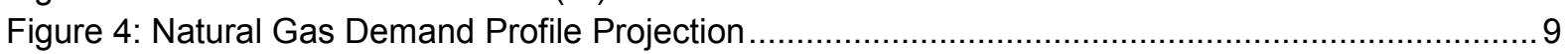

Figure 5: Development of Turkey's Annual Power Generation by Primary Energy Resources .......... 10

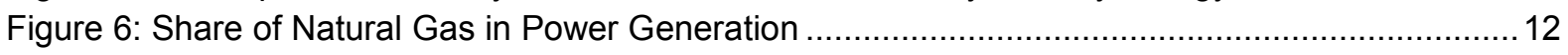

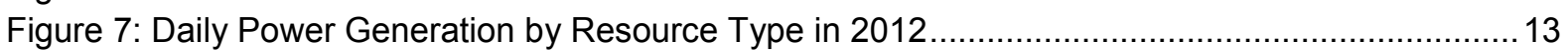

Figure 8: Power Generation by Primary Energy Resources and Installed Capacity - March 2013 ......14

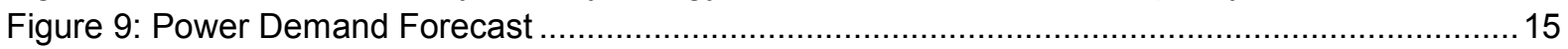

Figure 10: Annual Power Generation by Energy Type in 2012 and 2030 ...................................... 16

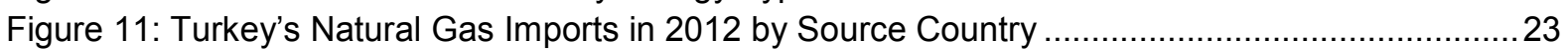

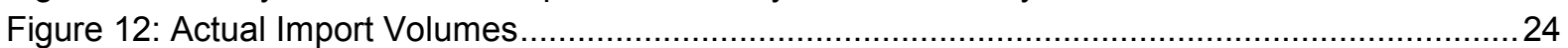

February 2014: Natural Gas in the Turkish Domestic Energy Market: Policies and Challenges 

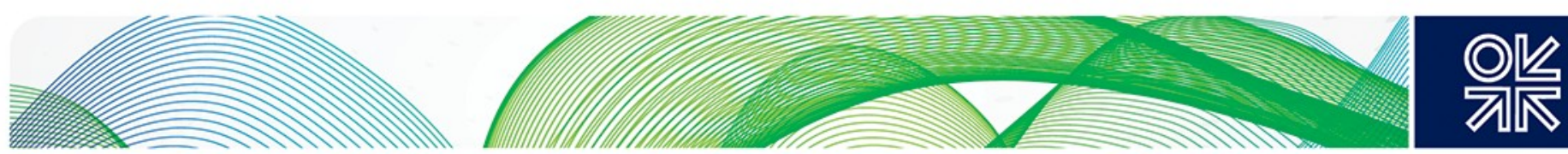

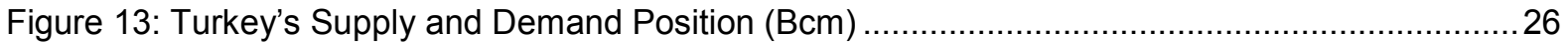

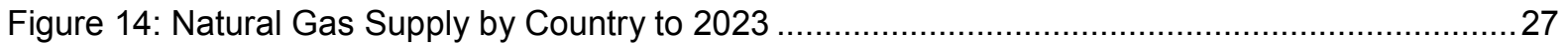

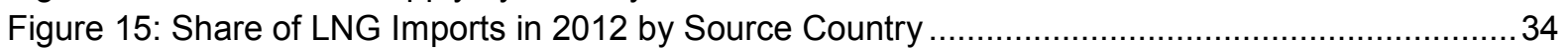

Figure 16: Private Sector Virtual Trade vs. Offtake Volumes and Market Share ................................. 36

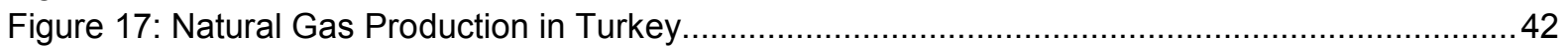

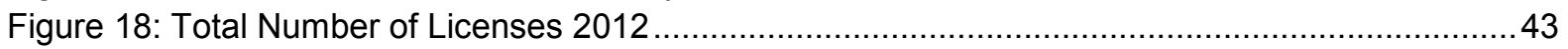

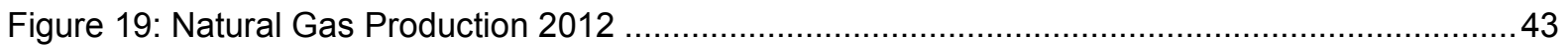

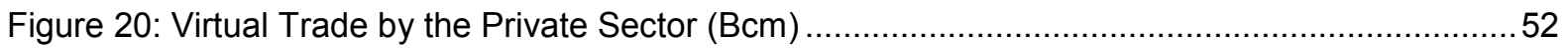

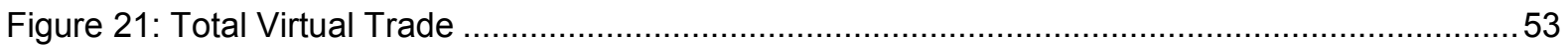

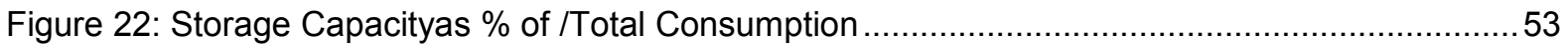

Figure 23: Total Investment by Tender Licensee Companies (TL million) ……..............................56

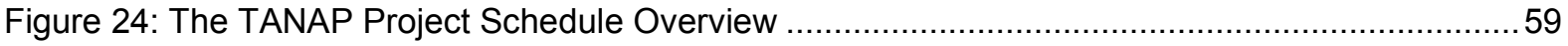

\section{Tables}

Table 1: Details of the Akkuyu and Sinop nuclear projects ........................................................14

Table 2: Power Generation Projects under Licensing Projects (2012) .................................... 16

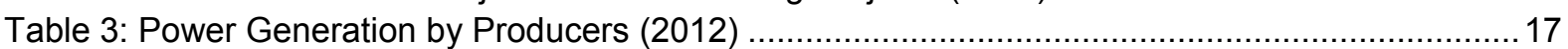

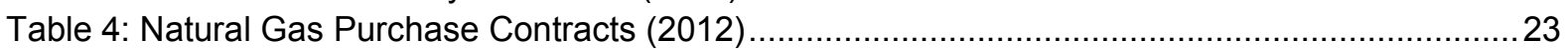

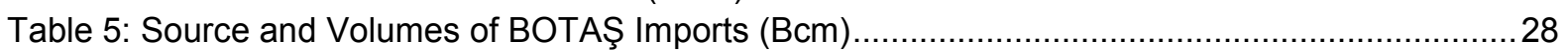

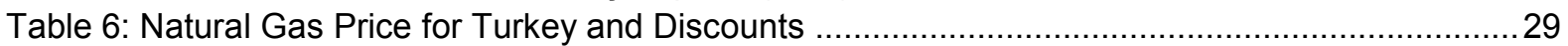

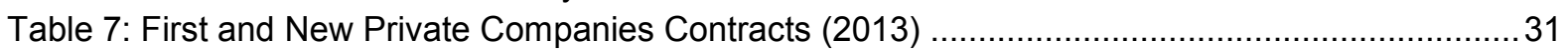

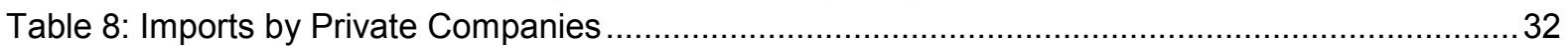

Table 9: The Share of Private Companies in Overall Natural Gas Import into Turkey, 2013 ..............33

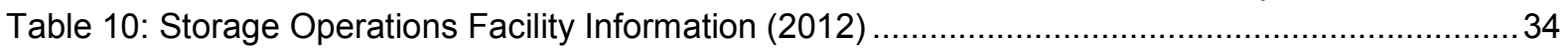

Table 11: Total Proved, Recoverable, Cumulative and Remaining Recoverable Gas ........................ 41

Table 12: Natural Gas Entry through Pipelines, LNG and Underground Storage .............................55

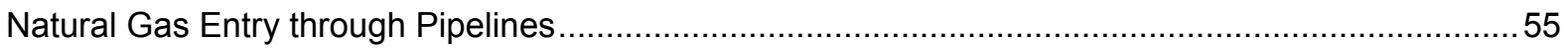

\section{Charts}

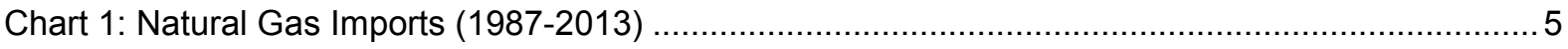

Chart 2: Turkey's GDP and Natural Gas Consumption Correlation .................................................

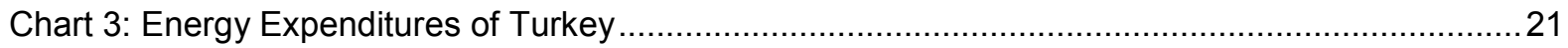

Chart 4: Natural Gas Demand (maximum demand, minimum demand, reference) December 2012.25

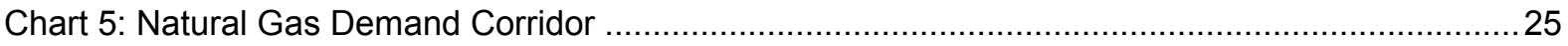

Chart 6: The share of LNG Consumption in the National Natural Gas Consumption (2008-2012, \%). 37

\section{Maps}

Map 1: Iraq oil and gas

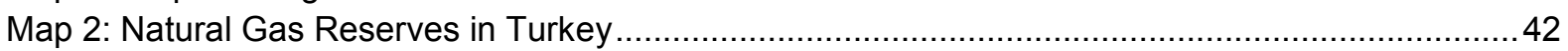

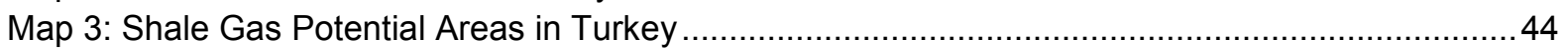

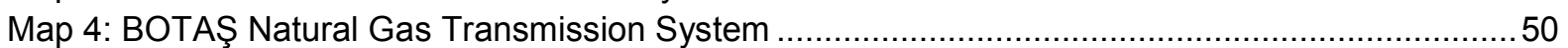

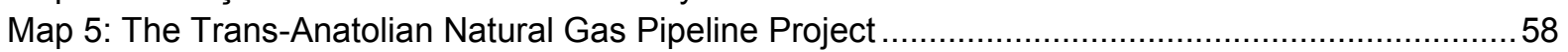

Map 6: East-West capacity through Turkey by building a dedicated pipeline ...................................59 

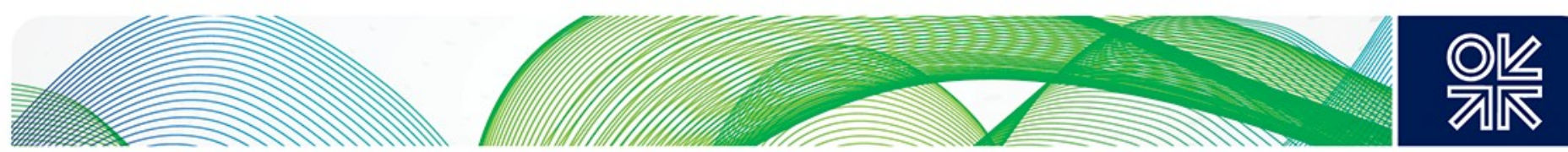

\section{Glossary}

BCM: Billion Cubic Meter

$\mathrm{BH}$ : Bosnia-Hezegovina

BO: Build Operator

BOT: Build Operator Transfer

BOTAŞ: Petroleum Pipeline Corporation (Boru Hatları İle Petrol Taşıma A.Ş)

EBB: Electronic Bulletin Board

EIA: Environmental Impact Assessment

EMRA: Energy Market Regulations Authority

EPIAŞ: Exchange Energy Markets Operation Inc.

DIVID: Association of Natural gas Importers and Exporters

GDEA: General Directorate of Energy Affairs

GDPA: General Directorate of Petroleum Affairs

GSPA: Gas Sales and Purchase Agreement

GDP: Growth Domestic Product

Gwh: Gegawatt/hour

HGA: Host Governmental Organisation

IAP: Ionian-Adriatic Pipeline

IGA: Intergovernmental Organisation

ICC: International Chamber of Commerce

KRG: The Kurdish Regional Government

LPG: Liquified Petroleum Gas

LNG: Liquefied Natural Gas

LTC: Long-Term Contract

MCM: Million Cubic Meter

MOU: Memorandum of Understanding

Mwh: Megawatt/hour

MENR: Ministry of Energy and Natural Resources

NBP: National Balancing Point

NGML: Natural Gas Market Law

NOP: Network Operation Principle

NW: Nabucco West

OECD: Organisation for Economic Co-Operation and Development

PKK: Kurdish National Organisation

SCPX: South Caucasus Pipeline Expansion

SGC: Southern Gas Corridor

SOCAR: State Oil Company of Azerbaijan Republic

TETAS: Turkish Electrisy Trade and Contract Cooperation

TL: Turkish Lira

ToP: Take or Pay

TPA: Third Party Access

TPAO: Turkish Petroleum Corporation

TSO: Transmission System Operator

SDII, SD2: Shah Deniz Phase II

TANAP: Trans-Anatolian Natural Gas Pipeline

TAP: Trans-Adriatic Pipeline

TEIAS: Turkish Electricity Transmission Company

TETAS: Turkish Electricity Trade \& Contract Corporation

TP: Transfer Point

TPIC: Turkish Petroleum International Company

TSO: Transmission System Operator

UDN: Ulusal Dengeleme Noktası 

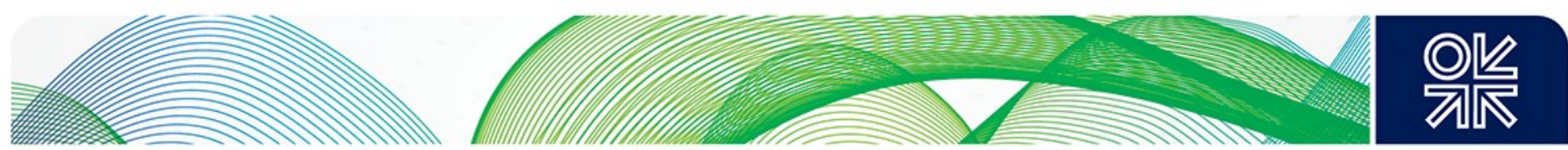

\section{Introduction}

The natural gas sector is one of Turkey's most important strategic industrial segments and has been under government control for decades due to its direct and indirect impact on economic development and growth. Clearly, proper regulation and direction of this segment by the government is crucial, as it directly influences the market framework within which energy intensive industries operate.

According to BOTAŞ' forecasts in 2012, Turkey's gas demand will almost double from $45 \mathrm{Bcm}$ in 2012 to $81 \mathrm{Bcm}$ by 2030. The main driver of this rapid growth will be gas-fired electricity generation, where demand, according to BOTAŞ, will most likely grow to up to $45 \mathrm{Bcm} / y e a r$ by 2030 . And this is despite the government's target to reduce the share of gas in the electricity generation sector from the current $45 \%$ to $30 \%$ or below, replacing gas with domestically produced coal, lignite, renewable energy and nuclear. However as demand for electricity is forecast to grow at 6-7\%/year, even with only $30 \%$ of the electricity market, gas demand growth will still be significant. The second driver is the household sector, where demand is forecast to grow from 8-9 Bcm in 2012 to $22.7 \mathrm{Bcm}$ in 2030 . The industrial sector is the third factor contributing to overall natural gas demand growth; it is forecast to rise from $12.8 \mathrm{Bcm}$ in 2019 to $14.2 \mathrm{Bcm}$ in 2030 . However this paper argues that, even in a high scenario, demand in Turkey is most likely to be at the level of around $67-70 \mathrm{Bcm}$ by 2030 , and the BOTAŞ projection of $81 \mathrm{Bcm}$ is optimistic.

The Organization of Economic Cooperation and Development's Economic Outlook ${ }^{1}$ foresees Turkey as having the fastest growing demand among OECD countries. Given the fact that Turkish domestic natural gas demand is expected to grow rapidly, there are several increasingly important tasks the Turkish government is faced with. These include:

1. ensuring Turkey's energy security, and

2. meeting demand in the long run and making sure that no periodic supply shortages occur during the next two decades.

On the supply side it is projected by BOTAŞ that there may be a supply deficit starting from 20152016 before an additional 6.6 Bcm/year of gas from Shah Deniz Phase-II (SDII) starts to be exported to the Turkish market from Azerbaijan via the TANAP pipeline from 2018. This paper also raises the possibility of a second "supply squeeze" from 2021, when major import contracts for Russian and Azerbaijani volumes expire. In line with the Natural Gas Market Law No. 4646 (NGML) which was passed in $2001,{ }^{2}$ BOTAŞ will not have the automatic right to renew the existing contracts and import gas from the suppliers with which it already has or had Gas Purchase and Sales Agreements (GPSAs). Private companies will now do this, with the exception, approved by the Council of Ministers, of the Shah Deniz Phase-II (SDII) contract. Furthermore, Turkey is planning to cover the supply/demand gap with increasing imports of (mainly spot) LNG if the price is advantageous over pipeline gas. Whether private companies will actually contract for replacement volumes is, of course, uncertain.

Iraqi gas, projected to be available from 2015 , is hoped to be a significant factor in satisfying Turkish demand growth at prices lower than those currently paid by Turkey under its long-term contracts. However due to political tensions between Baghdad and the Kurdish region, whether the gas will start to flow to the Turkish market from 2015 is also uncertain.

For this reason the government, which includes two main state entities supervising the energy sector - the Ministry of Energy and Natural Resources (MENR) as the decision-making and strategyprescribing body and the Energy Market Regulation Authority (EMRA) as the policy implementing 

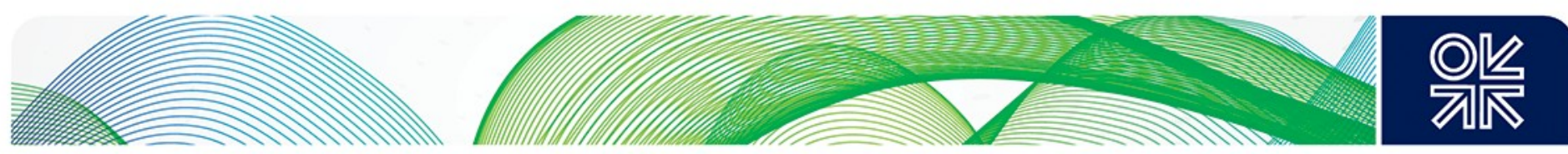

body - have been trying to achieve a progressive liberalisation of the domestic market and to increase the role of the private sector in all the segments of the natural gas market by reducing significantly the role of state monopolist BOTAŞ. The government is trying thereby to achieve the goal of creating a fully competitive market which could consequently bring about lower prices and stimulate further diversification of supply sources.

There are a number of developments in the Turkish domestic natural gas market that could potentially affect the supply/demand forecast. Throughout the last decade, the Turkish domestic natural gas market has been on the verge of transition, with a key role being played by the NGML, which was a crucial step forward in the liberalization process. Three major factors contributing to change in the Turkish market are:

- the government policy to reduce the share of natural gas in power generation;

- the changing trend in pricing in the market; and

- Turkish participation in international pipeline projects such as TANAP and TAP.

The Turkish government was determined to effect the liberalization of the domestic natural gas market by virtue of initiatives pursued between 2001 and 2007. The Natural Gas Market Law, promulgated in 2001, established the Energy Market Regulation Authority, which published regulations and communiqués and arranged privatization and license auctions. Additionally, the share of private (both Turkish and foreign) suppliers in the activities of gas import and wholesale, as well as transport, storage and LNG import noticeably increased. Another important development in the liberalization process was the opening of the transport system to third parties (so called Third Party Access) in 2004.

Further liberalization of the market came in 2007, as the monopoly of BOTAŞ in the wholesale sector was partially lifted and private suppliers gained access to the BOTAŞ grid to ship their gas. Liberalization has been aimed at creating a competitive environment for private suppliers that would bring natural gas to the domestic market at a competitive price and stimulate investment in the energy sector. The government's prime goal was to access multiple gas supply sources by taking advantage of Turkey's favourable geographical location and infrastructure to assist in meeting expected energy and gas demand growth in the next two decades.

Another recent development, which could be viewed as a part of this programme for market change, and could affect the supply/demand projections, is the policy of government to reduce the share of natural gas in power generation from the present $45 \%$ to $30 \%$ in the next few years.

The government's position on the liberalization of the market is not necessarily aligned with that of BOTAŞ. The MENR was intended to create a fully functioning free economy where the state monopolist's share of imports would be reduced from $80 \%$ to $20 \%$ by the end of 2009 , pursuant to the Law. According to the revised version of the Law drafted on May 30 2013, the reduction should be to $50 \%$, by an unspecified date. The national parliament has not yet approved the new draft version. A comparative analysis of both versions of the Law, and the reason why there was a need to draft a new Law and amendments, will be given in more detail in this study.

The liberalization of the domestic natural gas market in Turkey cannot nullify the import risks that state monopolist BOTAŞ faces, but it can significantly reduce them. The main risk pertaining to the long-term contractual offtake obligations with all its pipeline gas suppliers (Azerbaijan, Iran and Russia) is the take-or-pay clause present in all the long-term GSPAs. The BOTAŞ transport system's throughput capacity is not sufficiently developed to accept and ship all the contracted gas volume from the eastern suppliers due to the limited installed capacity of the existing compressor stations. BOTAŞ is able to take some $90 \%$ of the gas from the Trans-Balkan Gas Pipeline (the Western Line) and the Blue Stream pipeline from Russia, but has struggled to cope with volumes contracted from Azerbaijan and Iran. Therefore, the company has had to pay billions of dollars for 'untaken' gas. This has made the economics of gas imports for BOTAŞ commercially challenging.

Moreover, BOTAŞ has to subsidise domestic gas prices because of the high price of imported gas, especially from Iran (whose prices are the highest). The government of Turkey reimburses BOTAŞ 

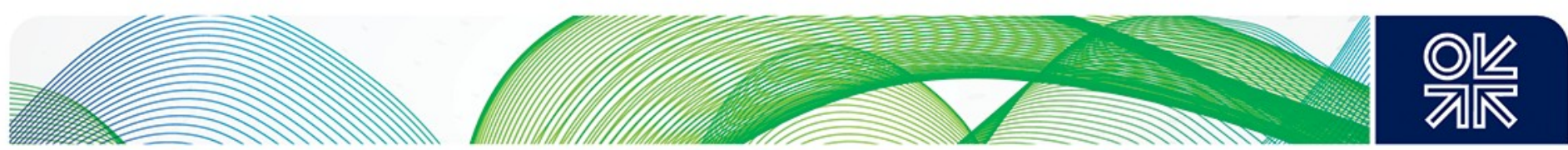

through subsidies and as a result both - the state and BOTAŞ itself - suffer financially from the contractually binding oil indexation of the gas price formula in the contracts.

With the import contract volume release programme as well as third party access to the BOTAŞ transport system, LNG and underground storage facilities, participation of private suppliers in the gas supply chain can mitigate BOTAŞ's commercial risks and challenges.

The main aim behind sharing gas imports/purchases with private suppliers, through contract and volume releases, is to stimulate a reduction in import prices and to develop a competitive environment in the domestic market such that the companies will bring cheaper gas into the market. Private suppliers in Turkey started the process of transferring import contracts from Gazprom via the Western Line in 2011 and started taking gas in January 2013, for a lower price than BOTAŞ had been paying. The companies' policy has been to negotiate lower prices in return for incentives to exporters, such as giving gas exporter companies a position in the Turkish domestic market. This is, no doubt, affecting the overall price formation regulated by the EMRA in the domestic market in a positive way.

It is a widely accepted view that it is not a realistic goal to reduce BOTAŞ's market share to $20 \%$ and some opposition parties criticize the government strategy, on the grounds that it will lead to losing state control over a most strategic segment of the economy. An alternative view is that there is no justification from a strategic perspective for controlling the mid- and downstream sector within the country, particularly as Turkey has no significant hydrocarbon resources or natural gas production. The presence of private suppliers in the import, transportation and wholesale sectors should minimize the risks to BOTAŞ, and ensure vibrant competition in the domestic natural gas market.

Each of these developments is elaborated on in the relevant sections of this study.

Section 2 addresses the main drivers of the rapid growth of natural gas demand and provides an indicative long-term supply/demand forecast. It also describes recent developments and the current situation in the domestic Turkish natural gas market, and provides an analytical prognosis on future developments.

Recognizing that the Turkish domestic natural gas market is in the early stages of liberalization, Section 3 addresses how Turkey is developing its relations with its pipeline gas suppliers such as Azerbaijan, Russia, Iran, and potentially Iraq, given the growing role of the private suppliers as new players gain more market share from BOTAŞ. This is especially significant given the strong growth trend of the Turkish domestic natural gas demand vis-a-vis its negligible domestic production. The likely evolutionary development path for natural gas in the overall Turkish energy mix is examined and the question whether this will be as a result of policy or merely by default is addressed.

The section also reviews the extent to which the expansion of LNG terminal receiving and storage capacity will contribute to further diversification of natural gas supply sources and Turkey's energy security.

The Regulatory Framework of the Turkish domestic natural gas market is addressed in Section 4 as well as the arrangements of the relevant operators relating to:

1. Natural Gas Market Law No. 4646, the fundamental step in establishing a liberal natural gas market in Turkey. The new draft of the law is examined and compared with the original version, and

2. Third Party Access (TPA) to the BOTAŞ transport grid.

This section also looks at the reasons for the lack of full implementation of the NGML within the last 12 years. Since its promulgation by the EMRA, the lack of full implementation is regarded as the main obstacle to Turkey becoming a liberalized natural gas trading hub.

Section 5 looks at the future development of Turkey's domestic natural gas market structure in terms of market architecture (hubs) and key players. Given that Turkey is currently the only gas market in 

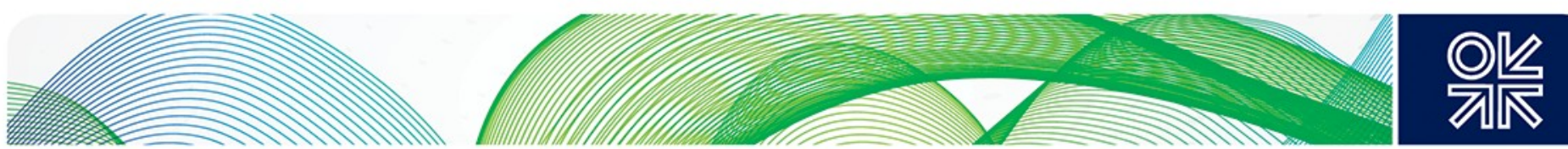

the European region showing significant and sustained demand growth, the section addresses whether regional suppliers should focus on the Turkish domestic natural gas market itself rather than considering Turkey as merely a transit country to the European heartland, where post-2008 demand has been at best stagnant.

This section also analyses Turkish participation in international projects such as TANAP (TransAnatolian Natural Gas Pipeline) and TAP (Trans-Adriatic Pipeline) and their strategic, commercial, political and technical advantageous and disadvantages for the country.

Section 6 sets out conclusions and recommendations. 

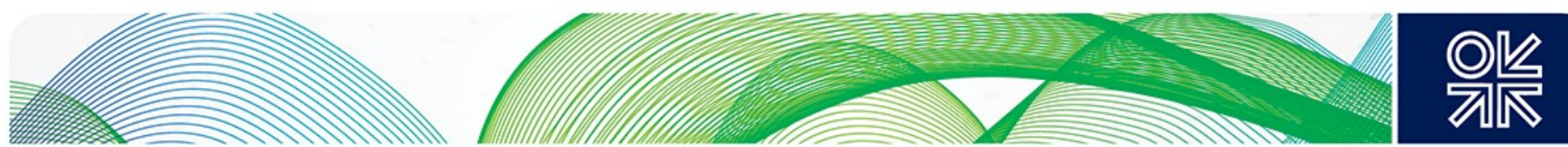

\section{Key Dynamics Contributing to Demand and Supply Growth: Market Outlook}

In terms of annual demand,Turkey is one of the largest gas markets in the European region - 45.2 Bcma in 2012. It is $98 \%$ dependent on imports of pipeline gas from three countries - Russia, Iran, and Azerbaijan - and LNG mainly from three countries - Algeria, Nigeria and Qatar (to some extent also from Egypt, before the Arab Spring).

Turkey began importing natural gas from 1988 following the signing of the first gas sales and purchase agreement (GSPA) between BOTAŞ and Soyuzgas of the USSR in 1986. Until that time natural gas did not play a part in Turkish primary energy consumption. Since then natural gas consumption has risen rapidly and in 2000 it reached $15 \mathrm{Bcm} / \mathrm{y}$ and by 2012 had tripled to 45.2 Bcm/y. In 2012 the natural gas share of primary energy consumption had reached $35 \%$. Figure 1 shows that natural gas consumption is expected to reach $47.6 \mathrm{Bcm} / \mathrm{y}$ in 2013.

Figure 1: Natural Gas Consumption in Turkey $(\mathrm{Bcm})$

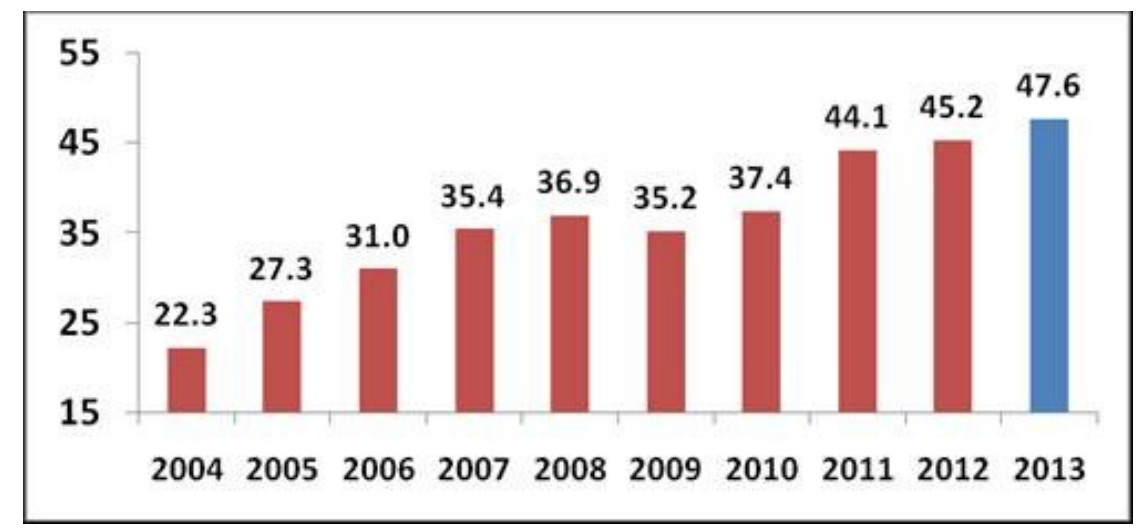

Source: DIVID (The Natural Gas Importer and Exporter Association)

Chart 1: Natural Gas Imports (1987-2013)

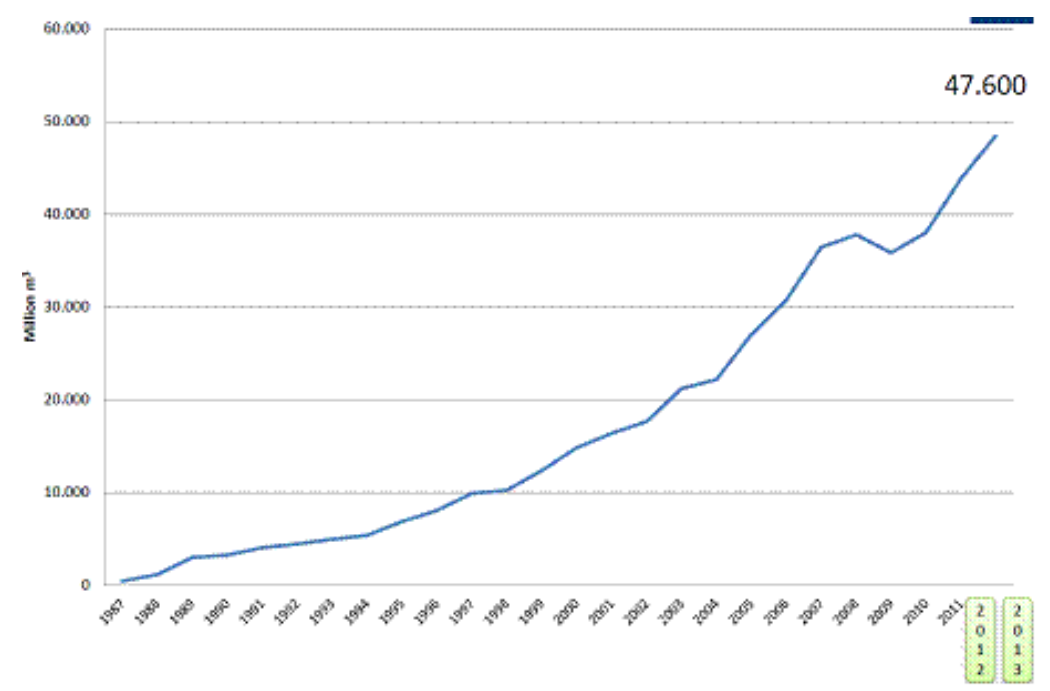

Source: EMRA, BOTAŞ

February 2014: Natural Gas in the Turkish Domestic Energy Market: Policies and Challenges 

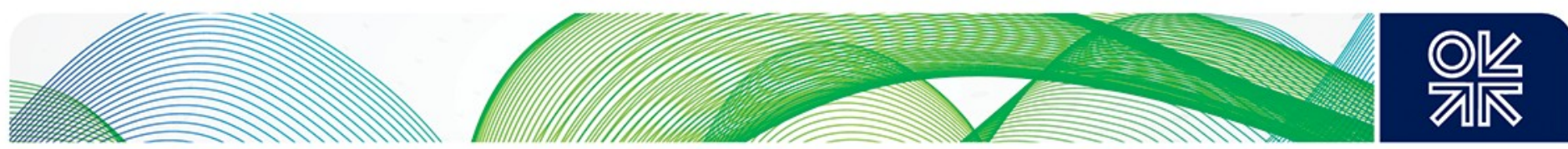

The main sectors of gas consumption in Turkey are (i) power, (ii) households and (iii) industry. Small amounts are also used in the refinery sector and private and public buildings. The rapid growth of natural gas demand over the last 30 years has mainly been driven by the growth of demand from power generation, which accounted for about $48 \%$ of gas consumption in 2012 . The power sector is dealt with in detail in the next sub-section; the situation in the other sectors is discussed here. Figure 2 shows the main areas of consumption.

Figure 2: Turkey's Natural Gas Consumption Profile (2012)

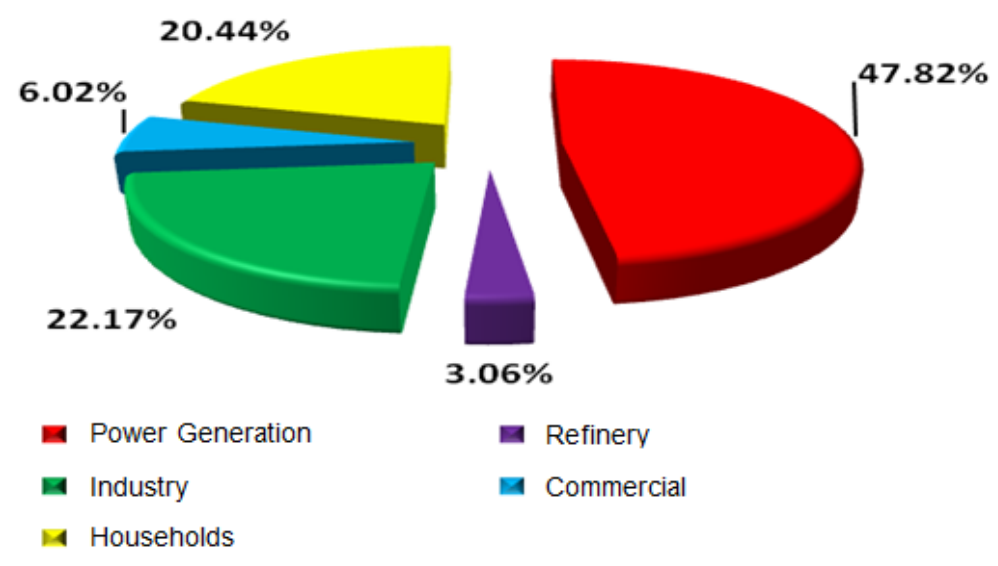

Source: EMRA

In the household sector the demand for natural gas has been growing strongly: average annual growth has been $1-2 \mathrm{Bcm} / \mathrm{y}$. Currently, the demand in the household sector is $8-9 \mathrm{Bcm} / \mathrm{y}$ but is projected to continue to grow by no more than $1 \mathrm{Bcm} / \mathrm{y}$ in the long run. This suggests reaching a level of $13-14 \mathrm{Bcm}$ in five years, i.e. a growth rate of $12.5-13 \% / \mathrm{y}$. BOTAŞ forecasts that demand from households will reach $22.7 \mathrm{Bcm} / \mathrm{y}$ by 2030 . The main driver of this growth in the residential sector is not the connection of the few remaining provinces unconnected to the BOTAŞ main transportation grid, but the growth and modernization of cities already connected, such as Istanbul, Ankara, Izmir, Gaziantep, and Adana. These are growing rapidly, with the construction of new housing and apartment blocks which contribute significantly to the natural gas demand growth in the household sector.

Some demand growth in the household sector is also expected as a result of the gasification of the south-eastern part of the country. The distribution system in Turkey now covers virtually all provinces, with a few exceptions such as Simak and Hakkari which are not connected because the investment would not be economically viable. Mardin is being gasified. However, it is important to note that following the ceasefire agreement with the Kurdish nationalist organisation, the PKK, there is a strong chance that energy companies such as Zorlu will be interested in supplying these regions, so that virtually all provinces should be connected to the distribution grid soon either by private companies or BOTAŞ.

Gasification of these regions is not, however, expected to contribute significantly to demand growth in the household sector. This is because almost $90 \%$ of the country has been gasified already in the last decade. In 2001 only 9 provinces were connected to the main transport system, but 82 have now been connected. The main consumption area with 4.5 million end users is greater Istanbul, which is fully gasified. A few south-western regions of the country such as the Antalya region (Gezipasha, Alanya, Alamur etc.) will not significantly add to overall consumption growth once connected to the main transport system, because of their mild climate. 

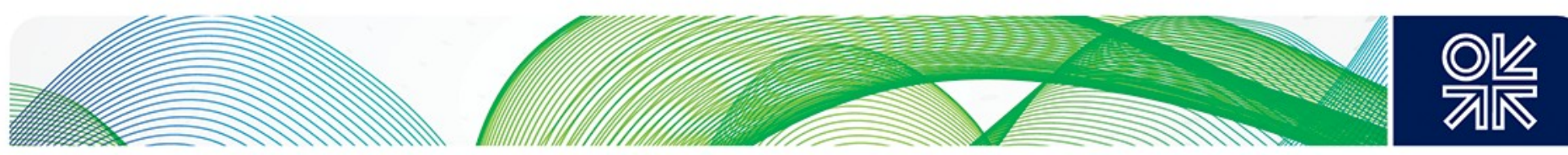

On the other hand, the government has been implementing an energy efficiency policy in the residential sector by installing central heating metering systems, which will incentivise more efficient consumption of natural gas.

In the Industry sector the share of natural gas in the fuel mix, which has been growing over the last 10 years, is likely to continue rising. Consumption by industry is directly linked to the overall economic growth of the country. According to the June 2012 OECD Economic Outlook, ${ }^{3}$ Turkey will have the fastest GDP growth of all OECD countries for the period from 2012 to 2017 with overall growth of $5.2 \% / y$. Turkey's GDP and natural gas consumption have correlated well only in a few periods between 1995 and 2009, when GDP growth and natural gas consumption were negative as a result of the global financial crisis. From 2010 onward, natural gas consumption and GDP growth have been well correlated. But from 2014 onwards it is likely that gas consumption will grow faster than GDP considering the rapid growth of gas in the electricity sector and the possible negative impact on the economy of the political situation of the country's immediate neighbourhood, for instance Kurdistan, Syria, Iraq, Iran.

\section{Chart 2: Turkey's GDP and Natural Gas Consumption Correlation}

\section{GDP vs. NG Consumption}

$30 \%$

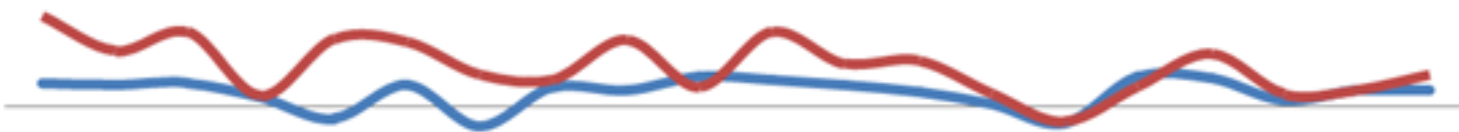

$19951996 \quad 1997 \quad 1998 \quad 1999200020012002 \quad 2003 \quad 2004 \quad 20052006 \quad 2007 \quad 2008 \quad 2009 \quad 2010201120122013 E 2014 E$

$$
\text { - GDP Growth }
$$

Source: OECD Economic outlook No: 91, June 2012

Figure 3: Annual Real GDP Growth (\%) Forecast in OECD Countries 2012-2017

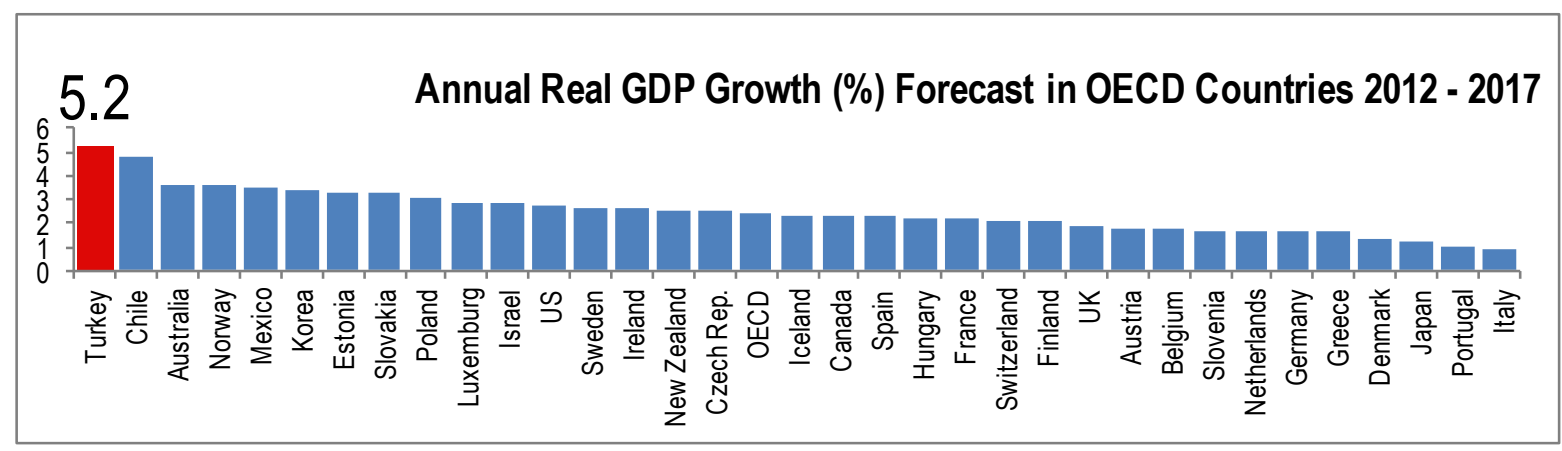

Source: OECD Economic outlook No: 91, June, 2012

The share of natural gas in the fuel mix in industry rose by $32 \%$ between 2009 and 2010 because of the revival of the economy after the economic crisis and GDP growth. The forecast of rapid GDP

\footnotetext{
${ }^{3}$ Medium and Long-Term Scenarios for Global Growth and Imbalances, OECD Economic Outlook, Volume 2012/1, Chapter 4, http://www.oecd.org/berlin/50405107.pdf
}

February 2014: Natural Gas in the Turkish Domestic Energy Market: Policies and Challenges 

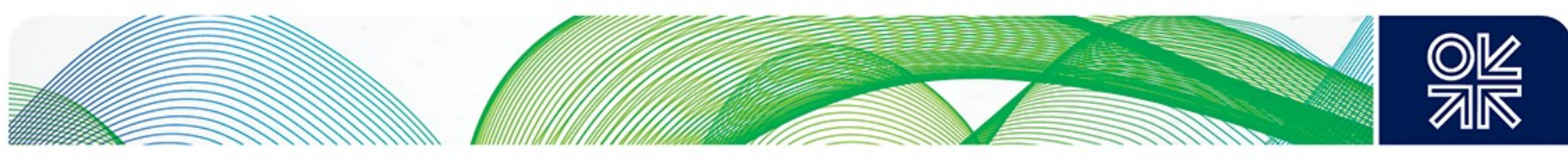

growth gives grounds for projecting future consumption growth in the sector. From 2010 to 2011, gas consumption in industry rose by around $35 \%$ for the same reason. In 2012 , GDP growth fell to $2.3 \%$, most likely due to political tensions in Turkey's immediate neighbourhood, and thus the gas consumption growth in the industry sector fell to about 15\%. It started to grow slowly again in 2013. According to BOTAŞ' forecasts, gas consumption in the industry sector will be $12.8 \mathrm{Bcm}$ in 2019 , and $14.1 \mathrm{Bcm}$ in 2030.

Such modest, but steady growth of the natural gas share in industry's fuel mix can be explained by the fact that the use of other energy sources such as LPG, coal and renewables is not commercially attractive. Natural gas is the cheapest fuel for this sector and it will most likely remain the best choice for industry in Turkey for the foreseeable future.

Although forecasts have been made that demand for natural gas in Turkey may double by 2030 , there are some factors that could moderate growth rates in the near future. These are:

1. Increasingly high dependence on natural gas imports (98\%) makes Turkey highly vulnerable to disruptions, especially during the seasonal peak demand period. For this reason alone, the government's long-term strategy is to lessen this dependence on natural gas and in the power sector replace it where possible by coal, lignite and renewables. The US has been exporting cheap coal to European and other countries due to the recent developments in the production of shale gas in US. More cheap coal could be imported into the Turkish market from the US at the expense of high priced natural gas imports;

2. The balance of payment deficit caused by the significant difference between energy imports and exports could be a second policy reason to lessen the share of natural gas in primary energy use.

3. Possible political instability during the next decade, as a result of either domestic factors (for instance recent protests) or neighbourhood factors (Kurdistan, Syria, Iraq, Iran) would probably affect the overall economic growth thus restraining demand growth.

4. 3 nuclear power plant projects - Akkuyu, Sinop, and a nuclear site on the Black Sea, $12 \mathrm{~km}$ from the Bulgarian border, are planned to be built in next decade. All three plants are in different development stages with Russian and Franco-Japanese companies.

None of these factors will substantially decrease natural gas consumption across all sectors but building nuclear power plant could significantly affect the volume of natural gas usage in the generation sector. There is some debate about demand growth between the public and private sectors (mainly foreign private companies). The latter believe that natural gas demand growth could be more modest. This paper argues that rapid demand growth is the most likely the case for the Turkish natural gas market in the next 20 years. However, unlike the BOTAŞ projection, demand is likely to grow to no more than around $70 \mathrm{Bcm} / \mathrm{y}$ by $2030 .{ }^{4}$ This is mainly because demand in the electricity sector will most likely be not $45 \mathrm{Bcm} / \mathrm{y}$ (BOTAŞ) but $30-33 \mathrm{Bcm} / \mathrm{y}$, because of the measures the government is undertaking to reduce the share of gas in power, including the nuclear power plant projects already underway. This estimate is supported by Figure 4 below, which shows projections by the Ministry of Energy and Natural Resources. These suggest that demand for gas in the power sector in Turkey can rise to up to $30 \mathrm{Bcm} / \mathrm{y}$ in 2018-20. However in 2021, once the three projected nuclear plants come online, the demand for gas in the electricity sector is likely to decrease to 28-29 $\mathrm{Bcm} / \mathrm{y}$. In the years starting from 2022, with little growth in electricity demand, the volume of gas consumed for power generation will most likely not exceed 30-33 Bcm/y. 

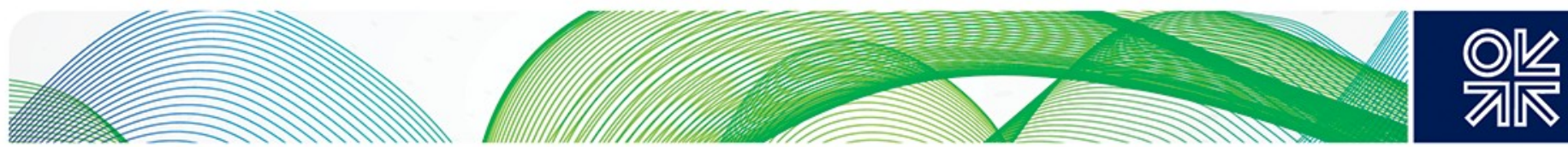

Figure 4: Natural Gas Demand Profile Projection

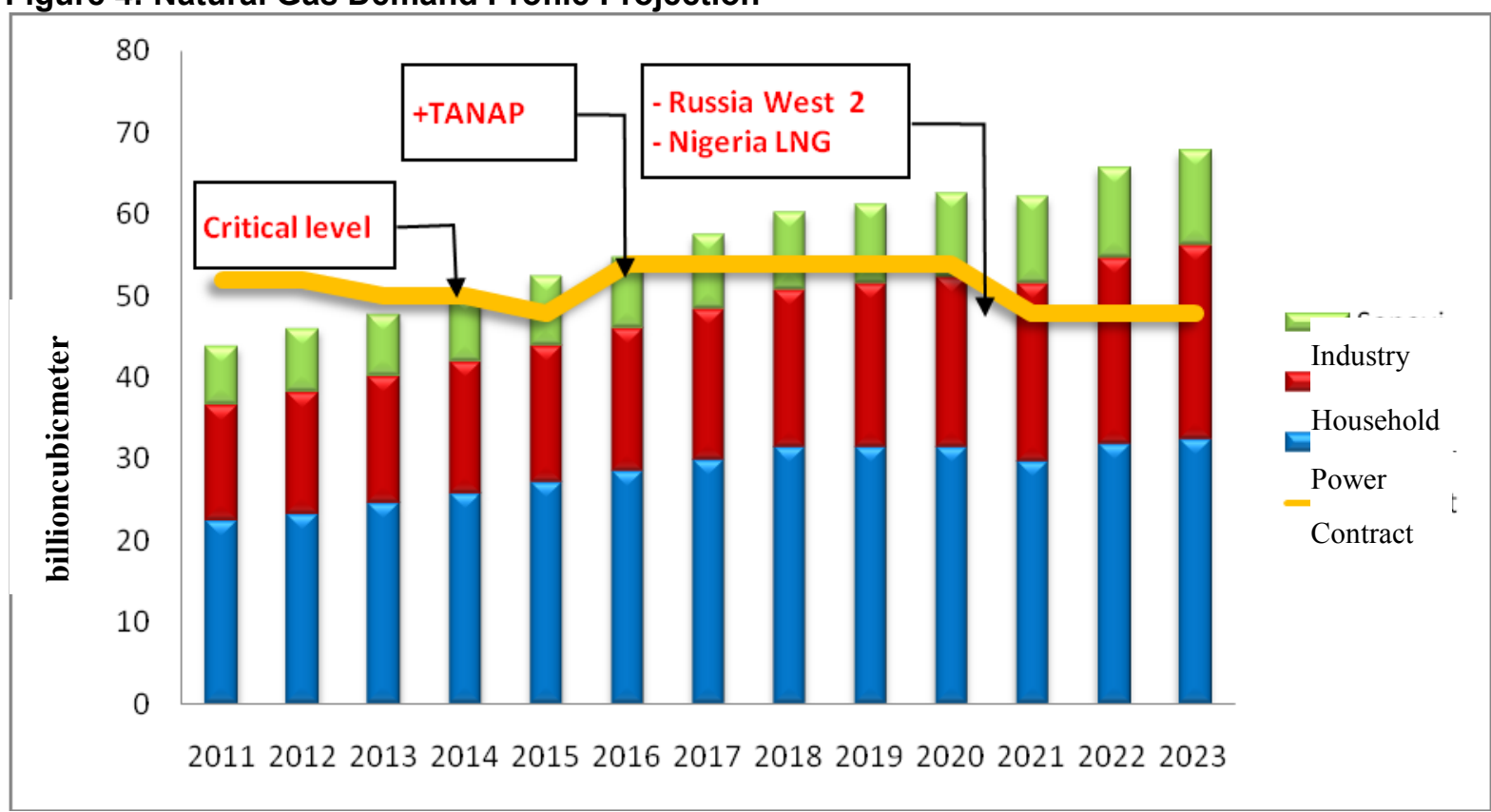

Source: Ministry of Energy and Natural Resources

Several key factors apart from those mentioned above will most likely contribute to overall gas demand growth:

1. Turkey is well positioned geographically and natural gas is and will be available from several sources. Of course, ultimately it is the price in the domestic market that will attract or discourage new suppliers such as Iraq, Israel, Cyprus and Lebanon to access the market, which is attractive to them because of the short transportation distance.

2. Where infrastructure costs are not excessive, gas prices are typically favourable compared to petroleum products and locally mined coal, which has very low quality (low calorific value). Natural gas has become the predominant fuel in all non-transportation energy uses, where it is not unfairly burdened fiscally.

3. The Turkish government and local municipal authorities recognize the superior emissions qualities of natural gas over other fuels such as high sulfur hard coal and lignite.

4. Despite the Turkish government's intention to reduce the share of natural gas in power generation, the EMRA has been increasing the number of natural gas licenses issued to private companies for power generation. It is expected to continue to do so, because of high power demand projections and a gradual increase of the share of the private sector in import, wholesale and distribution.

5. With market liberalization, more private sector, domestic and foreign risk capital is available to invest, and this will support demand growth. The existing and new wholesale companies are able to compete with BOTAŞ, because they can buy natural gas on the same terms as BOTAŞ, while their sales and purchase agreements have a lower average cost of natural gas supply than BOTAŞ'. Consumers currently supplied by BOTAŞ can switch to private sector suppliers at more advantageous terms. This will be examined in detail in the next sections.

6. Turkey may join the European Union Emission Trading Scheme to combat climate change as early as 2016. Under a decree published in the Turkish Official Gazette in 2012, more than 2,000 polluting industrial plant installations are required to monitor, report and verify their greenhouse gas emissions. Although for now monitoring is only voluntary, the government has already asked energy companies to measure their footprint. This could incentivize the companies to rely on more environmentally clean energy in power plants rather than the fuels such as coal and lignite. 

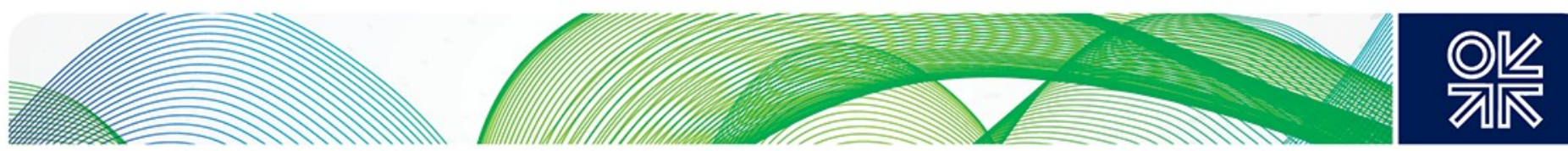

\subsection{Natural Gas in Power Generation and Installed Generation Capacity}

Turkey's power consumption has grown by a factor of five from 50TWh in 1990 to up to 240 TWh in 2012 (Figure 5). At the same time power generation from natural gas has increased 10 fold, from 10TWh in 1990 to more than 100TWh in 2012. This rapid increase of power consumption is explained by the rapidly growing economy and GDP, and supports forecasts that power demand will continue to grow up to 2030.

Figure 5: Development of Turkey's Annual Power Generation by Primary Energy Resources

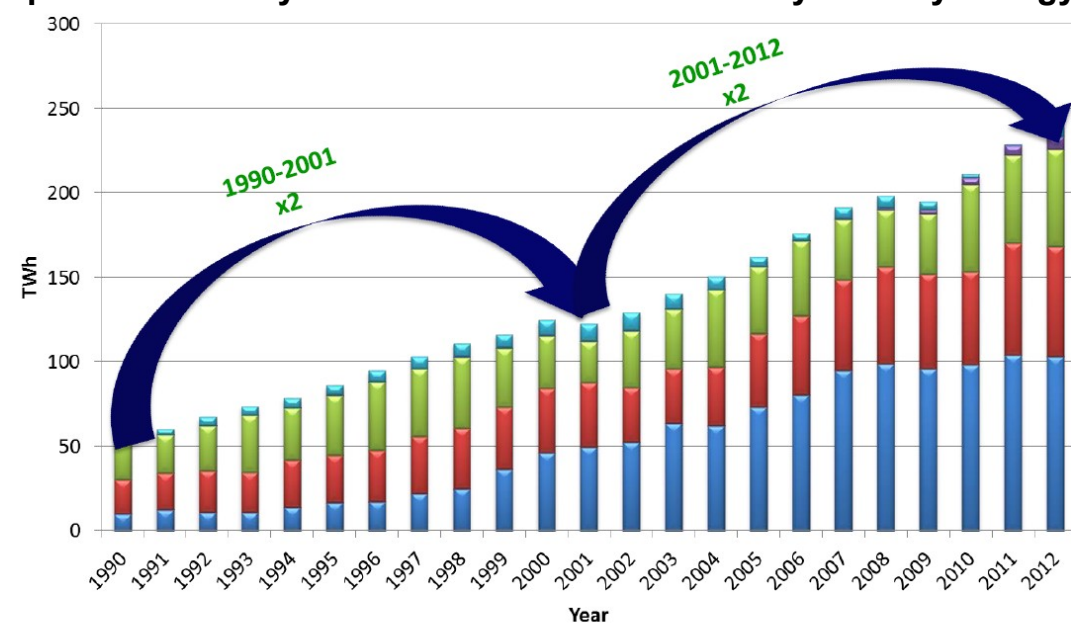

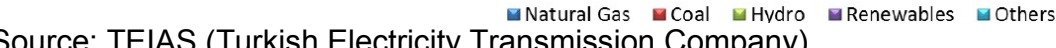

This paper argues that, despite the government's desire to reduce the share of gas in the electricity sector, through the measures described below, it is most likely that this policy will have limited results. Demand for gas in the electricity sector will continue to grow, to $35 \mathrm{Bcm} / \mathrm{y}$ by $2030 \mathrm{from} 21 \mathrm{Bcm} / \mathrm{y}$ at present, for the following reasons:

1. According to the Turkish Electricity Transmission Company (TEIAS) power demand in Turkey will grow by 6-7\%/year, driving up overall natural gas consumption in the generation sector. This will add approximately 8-9 Bcm/y to natural gas demand by 2023 .

2. EMRA is continuing to grant licenses to private sector companies to build more gas-fired power plants. These would require an additional $70 \mathrm{Bcm} / \mathrm{y}$ of gas supply if all were operational and if load factors of $90 \%$ are assumed. The probability that most of these plants will be built is high, due to their cost-effectiveness.

3. If Turkey is able to negotiate a better price for imported pipeline gas, there will be less incentive to persist with the policy of reducing the share of gas in the electricity sector.

4. There are two large gas-fired power generation projects underway that could further contribute to the share of gas in electricity sector. One of the largest gas-fired plants in Turkey - Hamitabat, which is directly fed from the Malkoçlar entry point in the north-west, ${ }^{5}$ is old and

\footnotetext{
${ }^{5}$ The Malkoçlar Main Metering Station determines the quantities and quality of natural gas entering Turkey via the western Russia-Turkey natural gas pipeline.
}

February 2014: Natural Gas in the Turkish Domestic Energy Market: Policies and Challenges 

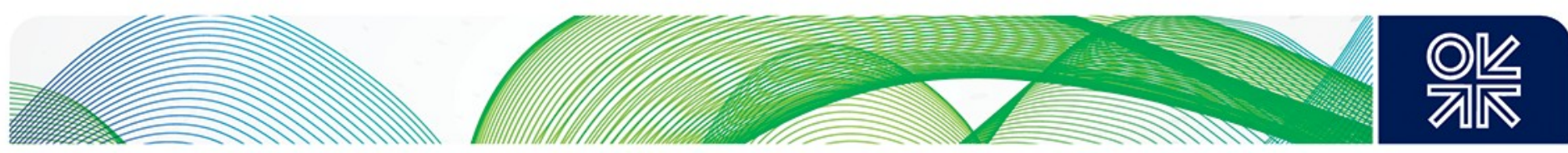

is the most inefficient plant in Turkey. The Limak company plans to invest up to $\$ 2$ billion to build two new gas-fired units with a capacity of up to 600MW at Hamitabat following its successful bid for the 1.2GW state-owned plant. Limak has a long-term ambition to have up to $5 \mathrm{GW}$ in operation within the next 10 years and the acquisition of Hamitabat is part of this strategy. Also the gas-fired Ak Energy Plant is planned to come online in July 2014 with a capacity of $800 \mathrm{MWh}$.

The rapid growth of natural gas demand during the last 30 years has mainly been driven by the growth of power consumption, in which natural gas had a share of more than $50 \%$ in 2010 . In 2012 however the natural gas share in the power generation fuel mix fell to $45 \%$, mainly because of the high price of gas imported from Russia and Iran, which led to the government's plan to reduce natural gas use in power generation to $30 \%$.

One of the main drivers of demand growth or decline in Turkey's energy demand in general and power generation in particular is the price. The price of Russian gas was $\$ 480 / 1,000 \mathrm{~m}^{3}$ in 2011 , and led Turkey to consider alternative fuels, mainly because of the difference between the price Turkey pays its suppliers and the consumer price in the domestic market. BOTAŞ sells natural gas at prices subsidised by the government, which bears part of the fiscal burden. If the gas price is high, power generators will strive instead to use domestically produced hard coal and lignite, and nuclear plants in the future. Although, the role of renewables is growing, it has not yet reached a level sufficient seriously to threaten the market share of fossil fuels.

According to MENR, the government's mid-term targets for power generation are to ${ }^{6}$ :

1. Use the full lignite and hard coal potential up to 2023;

2. Use all economically efficient hydro power potential;

3. Increase installed capacity of wind power plants up to $20,000 \mathrm{MW}$ by 2023 ;

4. Extend the consumption of solar energy;

5. Increase the share of renewable sources to $30 \%$ while reducing the share of natural gas to $30 \%$, of coal to $30 \%$ and of nuclear plants to $10 \%$; and

6. Accelerate the construction of nuclear power plants.

The high price of imported natural gas was the main incentive for the Turkish government to initiate the policy of reducing the share of natural gas in power generation to at least $30 \%$ by 2030 . Clearly, if the average price for imported natural gas falls, it is likely that demand will grow faster than is forecast. The question is to what extent the government policy is realistic. 

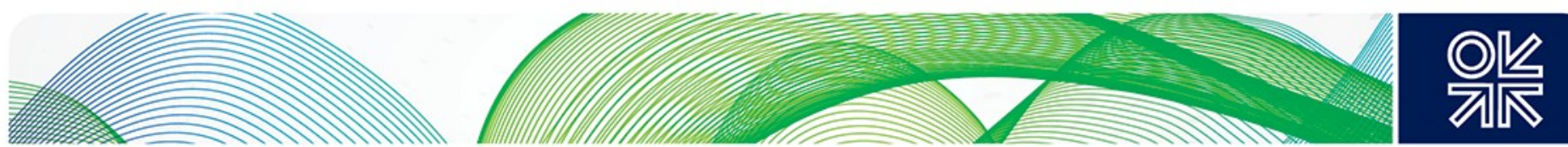

Figure 6: Share of Natural Gas in Power Generation

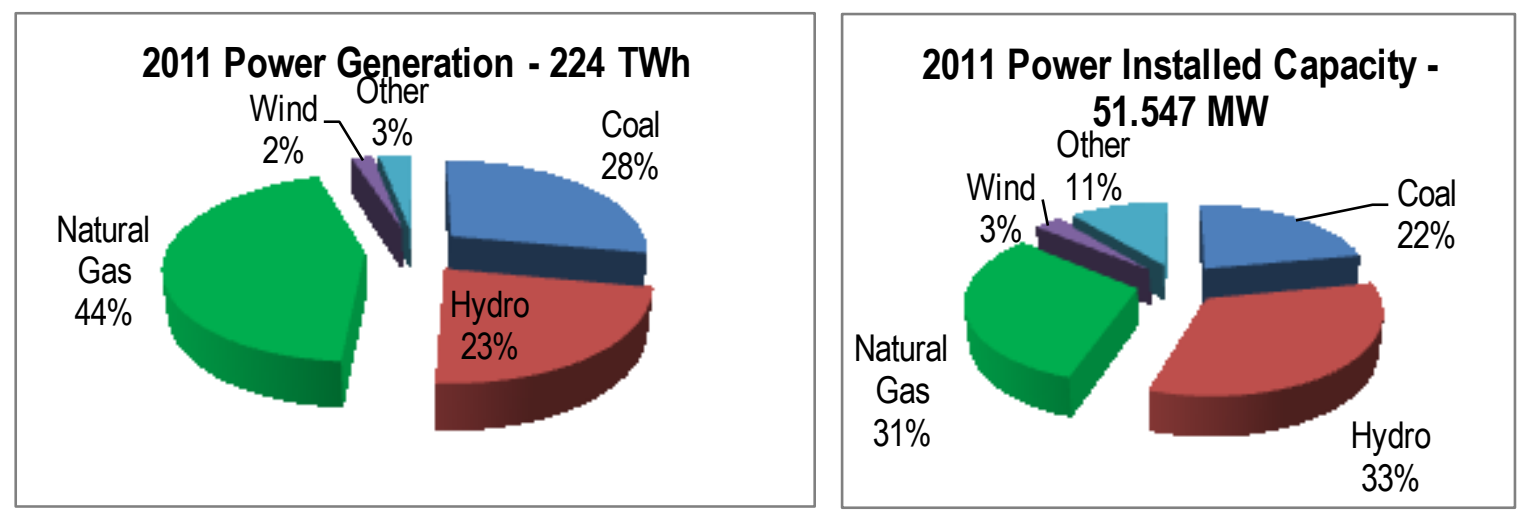

Source: EMRA

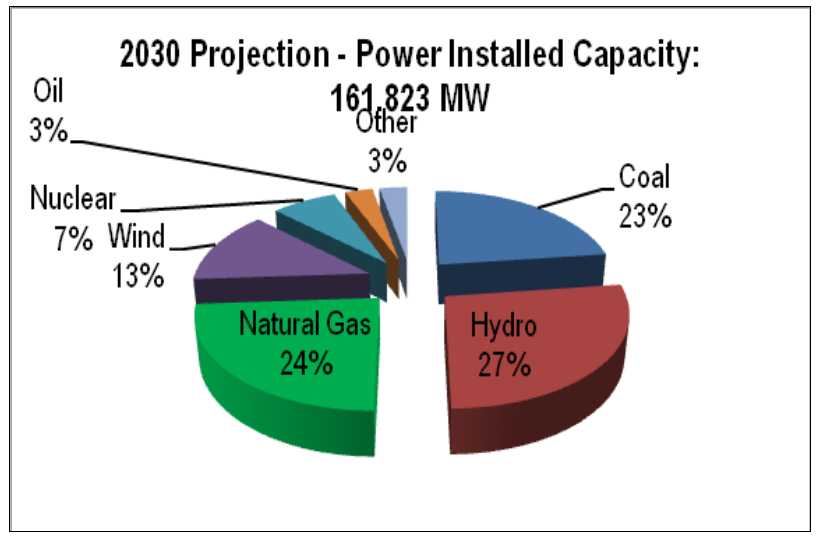

Source: EMRA, Power Market 2030 Projection, by Hasan Köktaş ${ }^{7}$

Another factor that affects the growth rate of natural gas in power generation is hydropower, which had a $23 \%$ share of Turkish power generation and 33\% of installed power capacity in 2011 (Figure 6). However, these figures depend on seasonal conditions. In particular output is high when there are more days of heavy rain, but during drought periods it needs to be balanced by natural gas. Besides, the use of natural gas for power generation has reduced the amount that the Turkish government needs to invest in hydropower development. Figure 7 below, based on information from the Turkish Electricity Transmission Authority, shows fluctuations of the share of hydro in the power fuel mix. The lowest share was $28 \%$ at the end of January, which is one of the driest months, whereas the highest share was in May (85\%). This is the one of the reason why gas demand in power is lowest in May.

\footnotetext{
${ }^{7}$ Presentation by Hasan Köktaş (Chairman of EMRA), INTE, 26th April 2011, Ankara, Turkey
} 

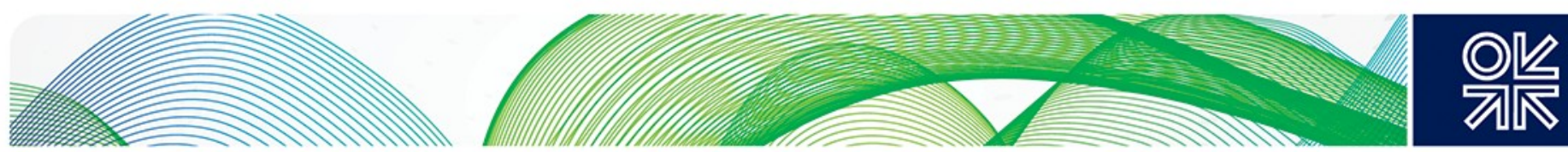

Figure 7: Daily Power Generation by Resource Type in 2012

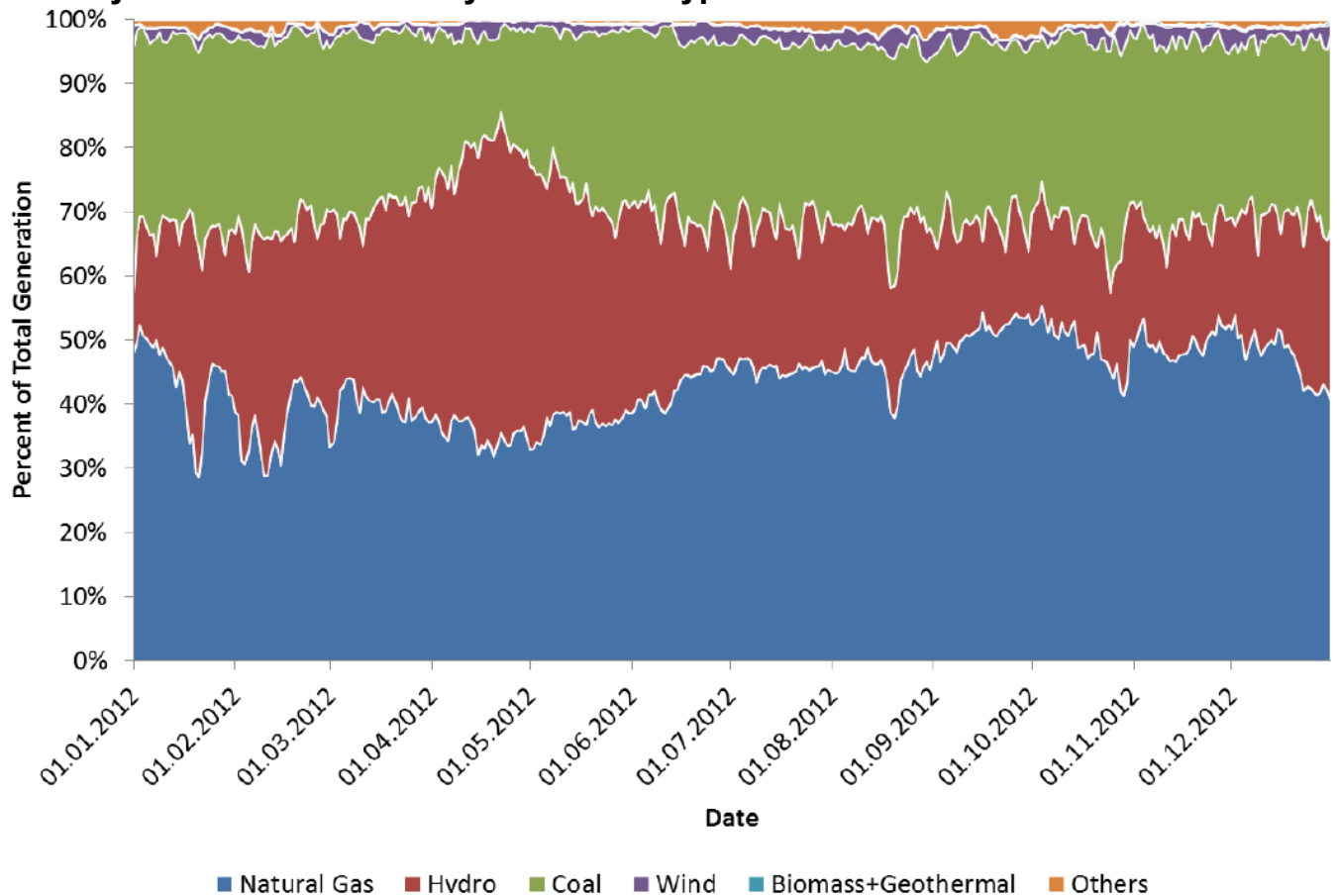

Source: TEIAS (Turkish Electricity Transmission Authority)

Finally, the government's plans to construct nuclear power stations, mentioned above, will reduce gas demand in the power sector. The two most significant projects are as follows:

1. The Akkuyu plant, which will have 4 AES-2006 units with gross capacity of 1,200 MW. Rosatom of Russia will build the plant and is committed to financing the project cost of $\$ 20$ billion. Turkish Electricity Trade \& Contract Corporation (TETAS) will buy $70 \%$ of the output of the first two units and $30 \%$ from units 3 and 4 at a fixed price of US $\phi 12.35 / \mathrm{kWh}$ for 15 years, or to 2030 . The remainder of the power will be sold by the project company on the open market. It is expected that the construction licence will be granted in mid 2014, enabling full construction to start in 2015 or January 2016. The company is expected to commission the first unit in $2021 .{ }^{8}$

2. The Sinop nuclear plant, with total capacity of about $4,600 \mathrm{MW}$ at a cost of $\$ 22$ billion, is expected to come online in 2023. The project consortium, led by Mitsubishi Heavy Industries (MHI) and Areva, with Itochu, has proposed four Atmea1 reactors. An intergovernmental agreement was signed with Japan for "exclusive negotiating rights to build a nuclear power plant" in May 2013. Subject to agreement by GdF Suez (which is to be the operator) the decision to proceed in 2016 has been made in 2013.

\footnotetext{
${ }^{8}$ World Nuclear Association (2013)
} 

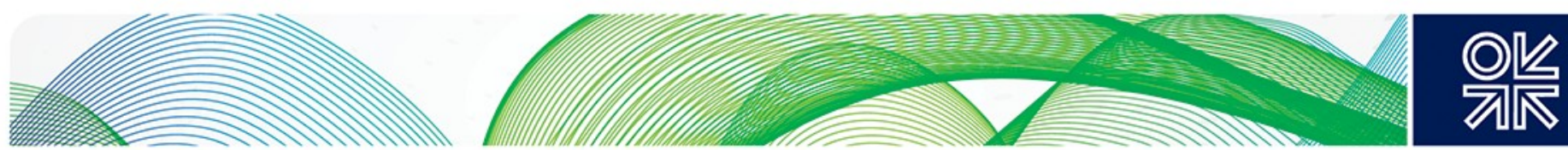

Table 1: Details of the Akkuyu and Sinop nuclear projects

\begin{tabular}{|c|c|c|c|c|}
\hline & Type & MWe gross & Start construction & Start operation \\
\hline Akkuyu 1 & VVER $^{9}-1200$ & 1200 & January 2016 & 2021 \\
\hline Akkuyu 2 & VVER-1200 & 1200 & 2017 & 2021 \\
\hline Akkuyu 3 & VVER-1200 & 1200 & 2018 & 2022 \\
\hline Akkuyu 4 & VVER-1200 & 1200 & 2019 & 2023 \\
\hline Sinop 1 & Atmea1 & 1150 & 2017 & 2023 \\
\hline Sinop 2 & Atmea1 & 1150 & & 2024 \\
\hline Sinop 3 & Atmea1 & 1150 & & $?$ \\
\hline Sinop 4 & Atmea1 & 1150 & & $?$ \\
\hline
\end{tabular}

Source: World Nuclear Association

When agreement for the development of the Sinop plant has been finalised, the energy ministry plans to announce the site for the third plant. ${ }^{10}$

Figure 8: Power Generation by Primary Energy Resources and Installed Capacity - March 2013
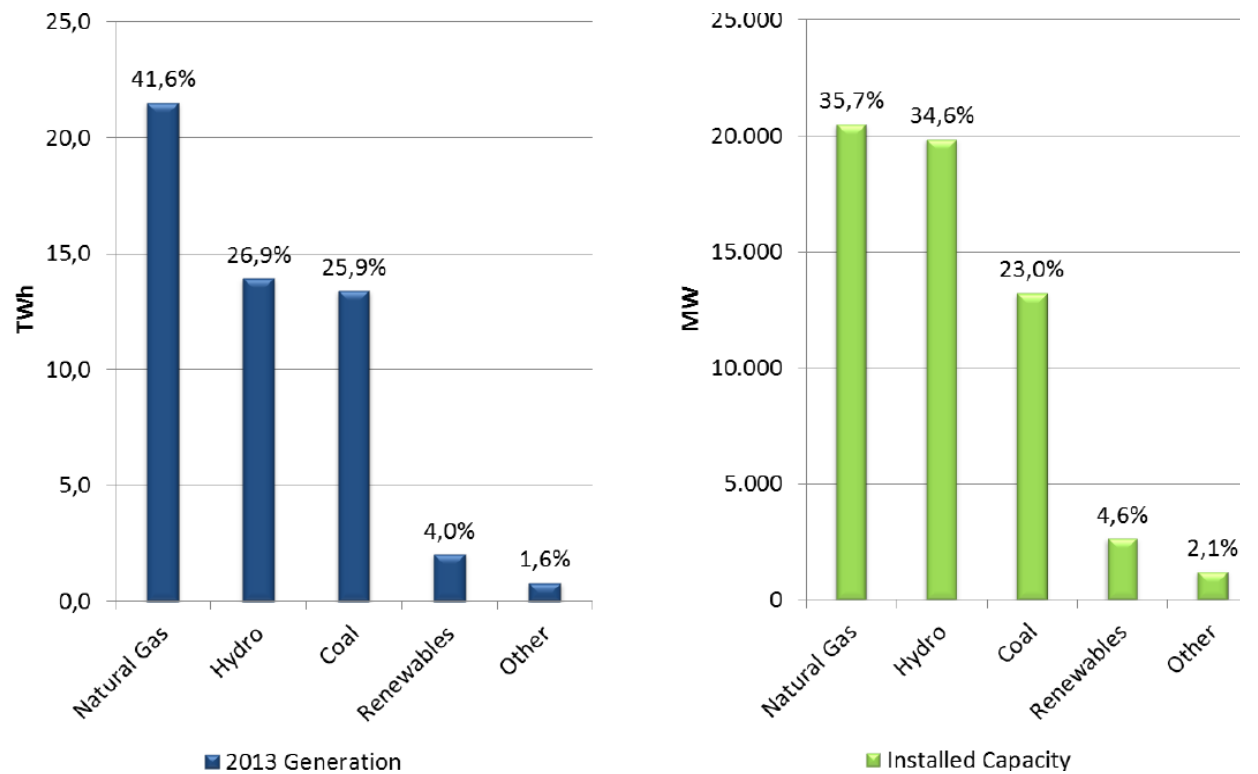

Source: TEIAS

Some natural gas power plants constructed in 1990s were given a special gas price concession, enabling them to pass the cost of natural gas (from BOTAŞ) through to customers. These contracts will start to expire in 2017. This will have an impact on gas consumption in power generation, and is one of the reasons behind the government's aim of reducing the natural gas share in this sector to at least $30 \%$ and replace it with hard coal, lignite and renewables. But, as we have seen, power consumption is forecast to grow by almost $7 \%$ /year by 2020 so that natural gas consumption in the power sector will increase by $8-9 \mathrm{Bcm} / \mathrm{y}$ even if its share is 30\%-24\% (See Figure 9).

\footnotetext{
${ }^{9}$ The Water-Water Power Reactor, (from Russian Vodo-Vodyanoi Energetichesky Reaktor) is a series of pressurised water reactor designs originally developed in the Soviet Union, and now Russia, by OKB Gidropress. Power output ranges from 300 MW to $1700 \mathrm{MW}$ with the latest Russian development of the design

${ }^{10}$ World Nuclear Association (2013)
}

February 2014: Natural Gas in the Turkish Domestic Energy Market: Policies and Challenges 

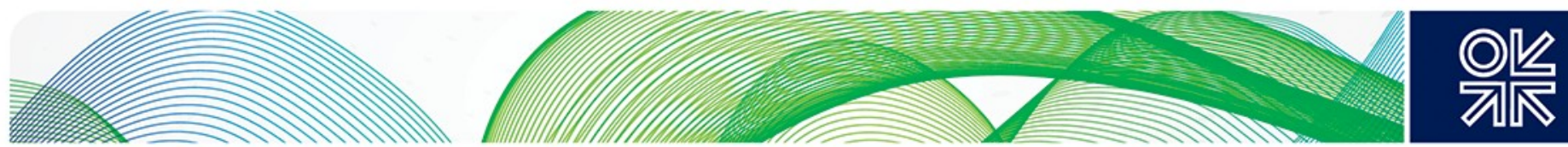

Figure 9: Power Demand Forecast

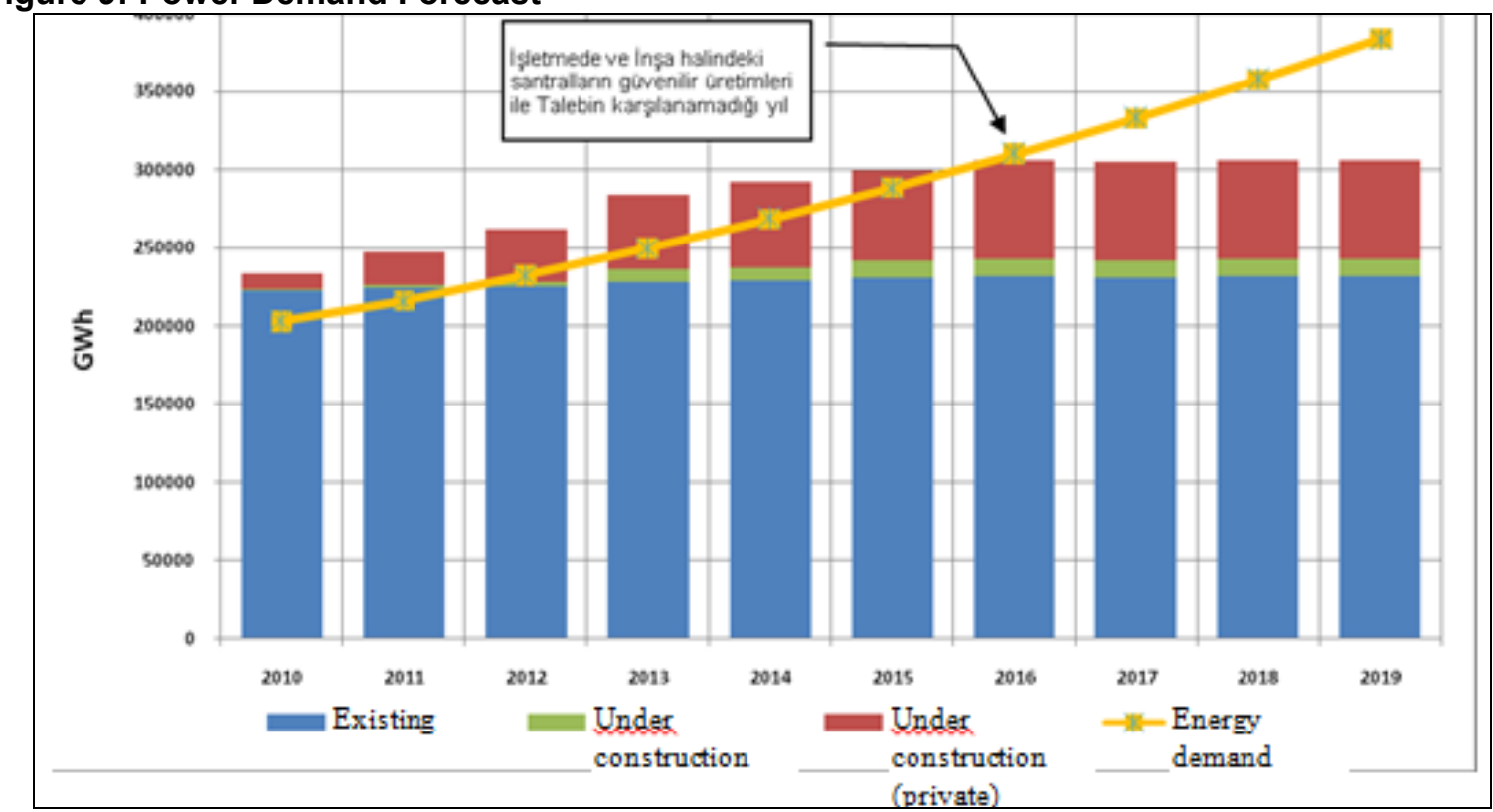

Source: EMRA

Despite the government target of reducing the share of natural gas in power generation, EMRA is continuing to approve installation licences for new gas-fired power plants. Table 2 shows that in 2012 alone 63 natural gas generation projects applied for licenses. EMRA reviewed and evaluated 40 of these, with a total installed capacity of $12.1 \mathrm{GW}$. In total 45 projects were approved by EMRA in 2012 and they will add $11.0 \mathrm{GW}$ to overall power capacity. Natural gas has the largest installed capacity of all generation types. However approval of construction of new gas-fired power plants does not automatically mean that these stations will be built. The private companies that obtained the licences will decide whether to build the plants or not, depending on the economics of the projects. 


\section{Table 2: Power Generation Projects under Licensing Projects (2012)}

\begin{tabular}{|c|c|c|c|c|c|c|c|c|}
\hline \multirow{2}{*}{$\begin{array}{l}\text { Fuel / } \\
\text { Resource } \\
\text { Type }\end{array}$} & \multicolumn{2}{|c|}{ Application } & \multicolumn{2}{|c|}{$\begin{array}{c}\text { Review- } \\
\text { Evaluation }\end{array}$} & \multicolumn{2}{|c|}{ Approved } & \multicolumn{2}{|r|}{ Total } \\
\hline & Qty & $\begin{array}{c}\text { Installed } \\
\text { Power } \\
\text { (MW) }\end{array}$ & Qty & $\begin{array}{l}\text { Installed } \\
\text { Power } \\
\text { (MW) }\end{array}$ & Qty & $\begin{array}{c}\text { Installed } \\
\text { Power } \\
\text { (MW) }\end{array}$ & Qty & $\begin{array}{c}\text { Installed } \\
\text { Power (MW) }\end{array}$ \\
\hline Wind & 2 & 47,20 & 9 & 408,60 & 33 & $1.701,90$ & 44 & $2.157,70$ \\
\hline Hydro & 68 & $1.171,00$ & 76 & $1.346,71$ & 295 & $3.707,66$ & 439 & $6.225,37$ \\
\hline Fuel Oil & 0 & 0,00 & 0 & 0,00 & 0 & 0,00 & 0 & 0,00 \\
\hline Natural Gas & 63 & $10.007,9$ & 40 & $12.100,12$ & 45 & $11.050,23$ & 148 & $33.158,25$ \\
\hline Lignite & 2 & $1.147,00$ & 0 & 0,00 & 1 & 135,00 & 3 & $1.282,00$ \\
\hline Coal & 14 & $10.369,6$ & 8 & $3.550,00$ & 4 & $2.295,00$ & 26 & $16.214,60$ \\
\hline Asphaltite & 0 & 0,00 & 0 & 0,00 & 1 & 135,00 & 1 & 135,00 \\
\hline Waste & 0 & 0,00 & 0 & 0,00 & 0 & 0,00 & 0 & 0,00 \\
\hline Geothermal & 10 & 264,00 & 8 & 105,95 & 2 & 155,00 & 20 & 524,95 \\
\hline Waste gas & 1 & 4,02 & 0 & 0,00 & 1 & 1,20 & 2 & 5,22 \\
\hline Biogas & 3 & 3,73 & 5 & 11,01 & 6 & 19,96 & 14 & 34,70 \\
\hline Biomass & 8 & 31,18 & 6 & 55,88 & 4 & 35,96 & 18 & 123,02 \\
\hline Solar & 0 & 0,00 & 0 & 0,00 & 0 & 0,00 & 0 & 0,00 \\
\hline Prit & & & & & & & 0 & \\
\hline Naptha & & & & & & & 0 & \\
\hline LPG & & & & & & & 0 & \\
\hline Nuclear & 0 & 0 & 1 & 4.800 & 0 & 0 & 1 & $4.800,00$ \\
\hline Total & 171 & 23.046 & 153 & 22.378 & 392 & 19.237 & 716 & $64.660,81$ \\
\hline
\end{tabular}

Source: The Chamber of Turkish Mechanical Engineers

This suggests that the government policy of reducing the share of gas in the electricity sector may not succeed, since it is most likely that many of the newly licensed gas-fired plants will be built.

\section{Figure 10: Annual Power Generation by Energy Type in 2012 and 2030}

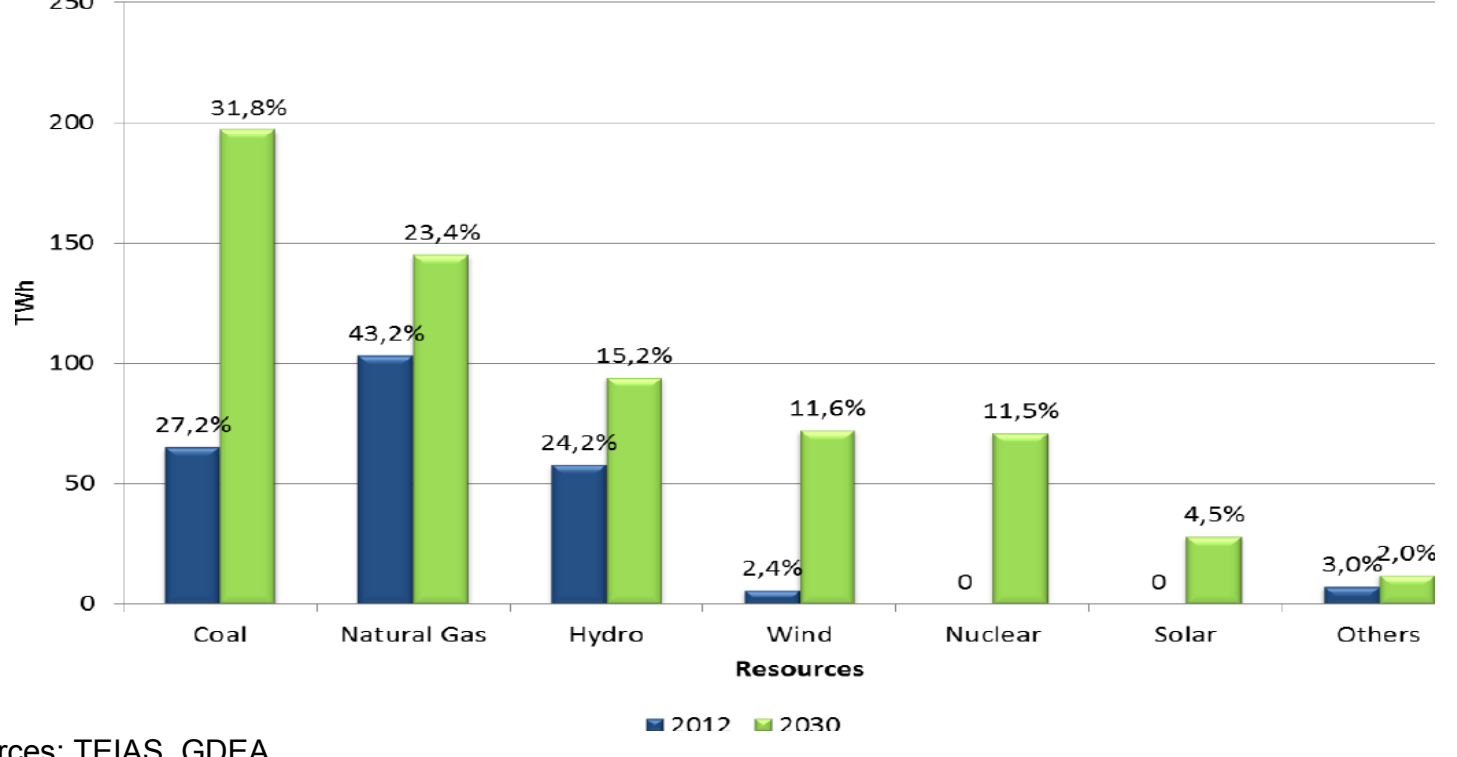

Sources: TEIAS, GDEA

If all power plants currently at the licensing stage are commissioned, then it reasonable to assume that an annual power generation capacity of $100 \mathrm{GW}$ would be reached as of 2030, and the forecast $7 \%$ annual growth rate can be realistic (See Figure 10). Of this, the lion's share will be natural gas-

February 2014: Natural Gas in the Turkish Domestic Energy Market: Policies and Challenges 

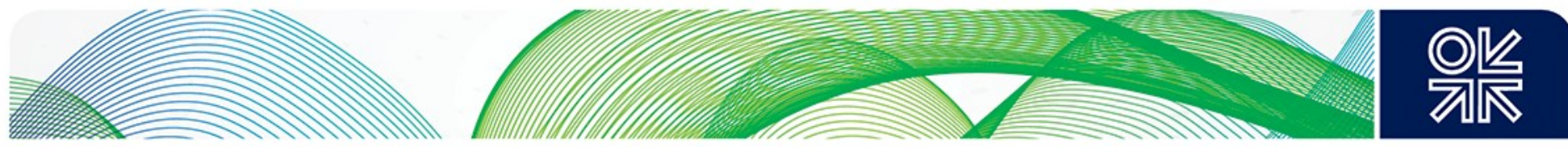

based. This means that natural gas-fired power plant projects that are in the licensing process, and at investment stage, amount to up to $33.2 \mathrm{GW}$ (See Table 2). This would represent about $90 \%$ of Turkey's existing installed capacity. These new natural gas-fired power plants would require an additional $70 \mathrm{Bcm} / \mathrm{y}$ of gas supply when operational and running at high load factors - but it is extremely unlikely that all these proposed plants will be built.

The low number of applications for licences for renewable projects can be explained by the poor commercial incentives to invest in such projects for both the public and private sector.

The government is aiming to privatize $100 \%$ of power generation. In 2012 the proportion of power generation capacity that was publicly owned was $38 \%$, and private producers owned $62 \%$. The power distribution networks of 21 Turkish provinces were due to be transferred to the private sector by the end of 2013, with a record number of transactions to privatize state enterprises expected to be concluded. In particular, several hydro power plants were due to be put up for privatization by the end of $2013 .^{11}$

Privatization could incentivise the private sector to invest more in alternative fuel-fired power generation. Companies that build renewables-based power generation plant with installed capacities of up to $500 \mathrm{~kW}$, micro co-generation facilities, and co-generation facilities with total efficiency of $80 \%$ (operating at $80 \%$ capacity), are exempted from the need to apply for licenses. This measure is designed to incentivize the private sector to develop non-natural gas-fired power generation. Table 3 shows the ownership of electricity generating assets, including hydro and thermal stations.

Table 3: Power Generation by Producers (2012)

\begin{tabular}{|c|c|c|}
\hline INSTITUTION & GWh & $\%$ \\
\hline EÜAŞ-Public Power Generation & $90.822,00$ & 38,0 \\
\hline Company & $90.822,00$ & 38,0 \\
\hline TOTAL PUBLIC & $43.087,00$ & 18,0 \\
\hline Build-Operate & $73.914,00$ & 30,9 \\
\hline Free Producers & $14.033,00$ & 5,9 \\
\hline Build, Operate, Transfer & $12.677,00$ & 5,3 \\
\hline Autoproducer & $4.547,00$ & 1,9 \\
\hline Transfer of Operating Rights & $148.258,00$ & 62,0 \\
\hline TOTAL PRIVATE SECTOR & $239.080,00$ & 100,0 \\
\hline GRAND TOTAL & & \\
\hline
\end{tabular}

Source: Turkish Electricity Transmission Authority

The natural gas-fired power plants to be commissioned in the coming years could require up to 12 $\mathrm{Bcm} / \mathrm{y}$ of gas at high load factors although gas-fired power generation will increase despite government incentives for renewable energies and other domestic resources. The explanation is that power demand per capita is expected to double by 2030 , so that even with a reduced gas share of $30 \%$ or less, the volume required could increase from $21 \mathrm{Bcm}$ in 2012 to about 33Bcm/year in 2030 .

\footnotetext{
${ }^{11}$ Some 21 Turkish provinces' power distribution networks to be managed by private sector, http://en.trend.az/capital/energy/2173695.html
}

February 2014: Natural Gas in the Turkish Domestic Energy Market: Policies and Challenges 

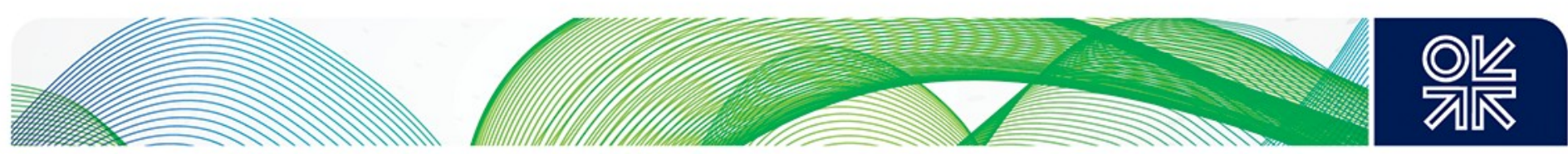

\section{Conclusions on demand}

To conclude, this paper anticipates that gas demand in Turkey will continue to grow strongly and is most likely to reach some $70 \mathrm{Bcm} / \mathrm{y}$ by 2030 . Along with gas demand growth in the household sector which could reach $22.7 \mathrm{Bcm}$ in 2030 from the current $8-9 \mathrm{Bcm} / \mathrm{y}$, and the industry sector which is likely to grow from $8 \mathrm{Bcm}$ in 2012 to $14 \mathrm{Bcm}$ in 2030, the main driver of this growth is the expected 6$7 \%$ growth of annual electricity demand. However the three nuclear power plants planned are likely to be a key factor in determining the share of natural gas in the electricity sector fuel mix in the long run. This could bring gas demand in the sector to no more than $30-33 \mathrm{Bcm}$ by 2030 .

Gas is the fuel of choice in the household, industry and electricity sectors in Turkey for a number of reasons described above. It is more economic than petroleum products and locally mined coal, which is of very low quality. Natural gas has become the predominant fuel in all non-transportation energy uses, where it is not unfairly burdened by fiscal policy. Turkey needs to negotiate favourable prices for gas imports, especially from Iran and Russia and obtain maximum benefit from new opportunities arising from its unique geographical position. From a business perspective, it is more profitable to rely on gas-fired electricity generation because it is relatively cheap to build, clean and flexible, easy to switch on and off without causing problems to the grid.

Natural gas is a highly political commodity and Turkey has suffered a great deal because of the high oil-linked prices charged by Russia and Iran. I would argue however that because we are now moving from a seller's market to a buyer's market following the US shale gas revolution (and outlook for US LNG exports) as well as the emergence of new supplies in the region (Azerbaijan, N. Iraq, Cyprus, Israel, and Lebanon) Turkey could negotiate better terms, making gas a more cost-effective fuel.

\subsection{Subsidies}

According to the new draft of amendments to the NGML: 'When subsidies are needed in order to support the consumers in particular regions or for particular purposes, these subsidies will be in the form of reimbursement to consumers, and there will be no price intervention'. ${ }^{12}$ This means that the subsidies in Turkey will not be removed in the foreseeable future.

The government decided to implement cost-based pricing mechanisms for energy products in 2008, with natural gas prices updated monthly based on the oil price and foreign exchange rate movements. The mechanism was successfully applied until mid-2009, when subsidization was introduced and gas prices were fixed until October 2011. During this period, BOTAŞ announced significant losses (Turkish Lira (TL) 1.3 billion in 2011 and TL 606 million in 2012). Losses from gas sales to the domestic market alone were TL 5 billion, almost 4 times more than in 2011. TL 606 million is the loss after compensating income from storage and transport systems, its most profitable business in Turkey.

Since subsidisation came into force in October 2011, natural gas prices have been raised 3 times by a total of $49.9 \%$. Currently, the average pipeline gas price for Turkey is around $\$ 435 / 1,000 \mathrm{~m}^{3}$ (based on the statements of government representatives). The price for industrial customers is $\$ 359 / 1000 \mathrm{~m}^{3}$, compared with $\$ 390 / 1000 \mathrm{~m}^{3}$ for households $-45 \$$ less than the BOTAŞ purchase price.

There are BO (Build Operate) and BOT (Build Operate Transfer) power plants in Turkey from which the government has guaranteed to take or pay for total energy generated for a fixed number of years. Natural gas fuel costs are passed through in their price to government and BO-BOT operators therefore have no gas price risk. Approximately $1 / 3$ of BOTAŞ' gas is consumed in BO-BOT plants.

\footnotetext{
${ }^{12}$ The draft of the amendments has not been published by EMRA yet and it is not available online. It is expected to be approved by the Parliament in 2014 and to be published after the approval.
} 

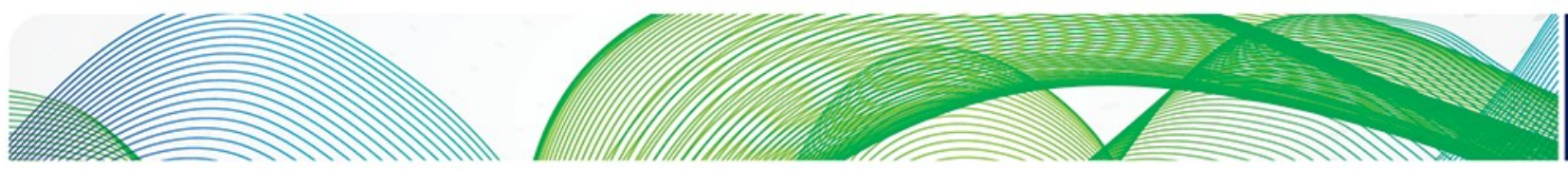

\section{O는}

BOTAŞ has been trying to offset its losses elsewhere by selling expensive gas to these plants. From the most recent information available, BOTAŞ charges around $\$ 520 / 1,000 \mathrm{~m}^{3}$ for gas to BO-BOTs. Consequently the Turkish treasury is subsidising lower-priced BOTAŞ sales to other sectors through BO-BOT plants.

It is worth mentioning that the scale of the subsidy provided by the government to customers through low, regulated tariffs is not stimulating excessive demand. The price for households $\left(\$ 390 / 1,000 \mathrm{~m}^{3}\right)$ is still high for the Turkish population average income and the same for industry. 

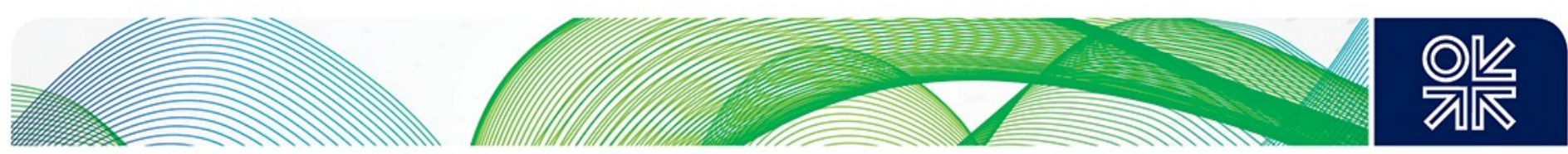

\section{Security of Supply}

\section{Question: Supply surplus or shortage?}

Given the likely trend of Turkish natural gas demand growth outlook for reasons described in the previous section, there could be a supply shortage:

a) After 2015-16 due to rising demand, before the start-up of deliveries from Shah Deniz II in 2018;

b) After 2021-2022 when a possible supply squeeze could occur, arising from the expiry of the Shah Deniz I and the Gazprom Western Line contracts.

Furthermore, apart from the expiry of contracts, the other difficulties that Turkey may face post 2016, regional gas shortages, especially at times of peak demand, arising mainly from Turkey's infrastructure problems rather than from national gas supply shortages as such. In the event that natural gas-fired plant in Turkey needs to operate at full capacity during cold winter days, the highest daily value of gas dispatch via the BOTAŞ transmission system may reach a maximum 180-200 $\mathrm{Mmcm}$. Given the demand growth in all sectors of the country and the fact that the new underground storage facilities will not be operational for several years, daily demand in winter time may exceed maximum daily dispatch capacity and therefore supply shortages may occur because of constrained network capacity.

Having said that, Turkey could face supply shortages if:

a) The imported volume of spot LNG is not increased following the expansion of LNG import and storage capacity;

b) Turkey does not import gas from Iraq starting from around 2015-16. (Gas export from Iraq is fraught with political difficulties that are described later in this section).

c) BOTAŞ does not invest in high-pressure compressor stations on the eastern transmission system to enable it to import all the contracted volume from Iran and Azerbaijan. This is especially important during the winter peak demand period when demand is almost double summer demand, and is expected to grow rapidly in the next six years (See Charts5, 6).

d) Supplier countries may not wish to conclude new contracts with several private companies instead of one - BOTAŞ. There is a potential risk that Russia, which exports $10 \mathrm{Bcm} / \mathrm{y}$ of gas via the Western Line, will refuse to renew the contract that expires in 2021, since it will be required to sell the gas to companies other than BOTAŞ for a lower price, as the companies will not be subsidised by the Turkish government as BOTAŞ is.

Notwithstanding that Turkey's demand for natural gas is expected to rise significantly in the long run, apart from the contract signed with the Shah Deniz consortium for the import of gas from Phase II, there are no new actual contracts on the table that would increase Turkey's pipeline gas imports after 2015. The launch of gas imports based on the supply contract signed with Turkmenistan in 1999 still faces strong opposition from Russia if it requires a Trans-Caspian pipeline solution.

Clearly Turkey's biggest gas supplier, Russia, is capable of supplying additional volumes via existing infrastructure if needed. The problem with Russia is price, and Turkey would be extremely reluctant to increase import volumes from this source at current contract prices. This is the main reason why Turkey wants to reduce its dependence on Russia and Iran and substitute volumes from Iraq and Azerbaijan in the long run. Turkey will make every effort to avoid negotiating to purchase such imports from a disadvantaged position.

Consequently, the most critical time for supply shortage may be the years 2015-2016 (Figure 13; 14) as Turkey will have a fewer alternative options to meet the rising demand. Within the timeframe of 2018-2022 Turkey will have more options. These are mainly $6.6 \mathrm{Bcma}$ of SDII gas, up to $5 \mathrm{Bcma}$ of Iraqi gas, projected nuclear plants (which would displace gas demand growth) as well as LNG and underground storage facilities expansion. 

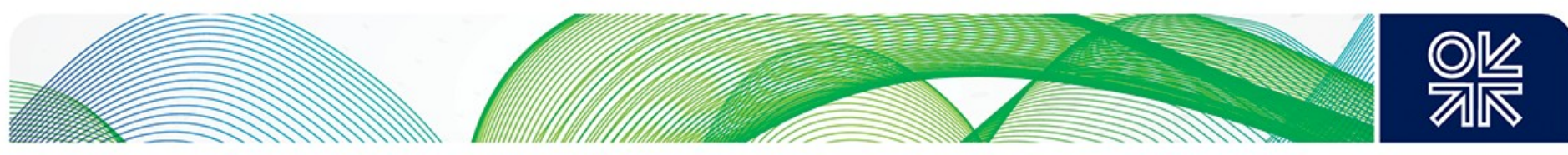

In the light of these realities, the Turkish natural gas market is currently undergoing massive structural change and no doubt this will affect future supply/demand projections. The Turkish natural gas market has been on a transitional path throughout the last decade, led by a few developments, mainly:

a) the promulgation of the NGML;

b) the government policy to lessen the share of natural gas in power generation in the medium term;

c) the changing trends in pricing on the market, and

d) participation of the country in international projects such as TANAP and TAP.

The supply/demand forecast and market outlook is therefore uncertain. Once government policies are realized every segment of the market will be changed. This is especially true for supply forecasts where there is uncertainty about the future of the contracts with Azerbaijan, Nigeria LNG, and the Russia Western Line after 2019.

Once fully implemented the NGML has great potential to change supply projections, if it creates competition between private companies interested in bringing more natural gas to the market at competitive prices. The law facilitates a more efficient use of the transmission system, and it is increasingly attracting multinationals' interest. New investors, attracted by wholesale competition, are potentially emerging as importers, paving the way towards import competition. This could bring more natural gas to market in an efficient way.

The government's number one concern is whether it can provide a secure supply of natural gas in an increasingly competitive domestic wholesale market to meet the growing demand.

Another concern of the government and one of the main security problems for the country is its almost entire $(98 \%)$ dependence on imported natural gas, due to the modest scale of domestic production. This affects the national economy as well as natural gas supply security, because of the balance of payments consequences. In 2012 alone, Turkey spent $\$ 60$ billion on energy imports and this will be doubled by 2030 as a result of demand growth (Chart 3 ).

\section{Chart 3: Energy Expenditures of Turkey}

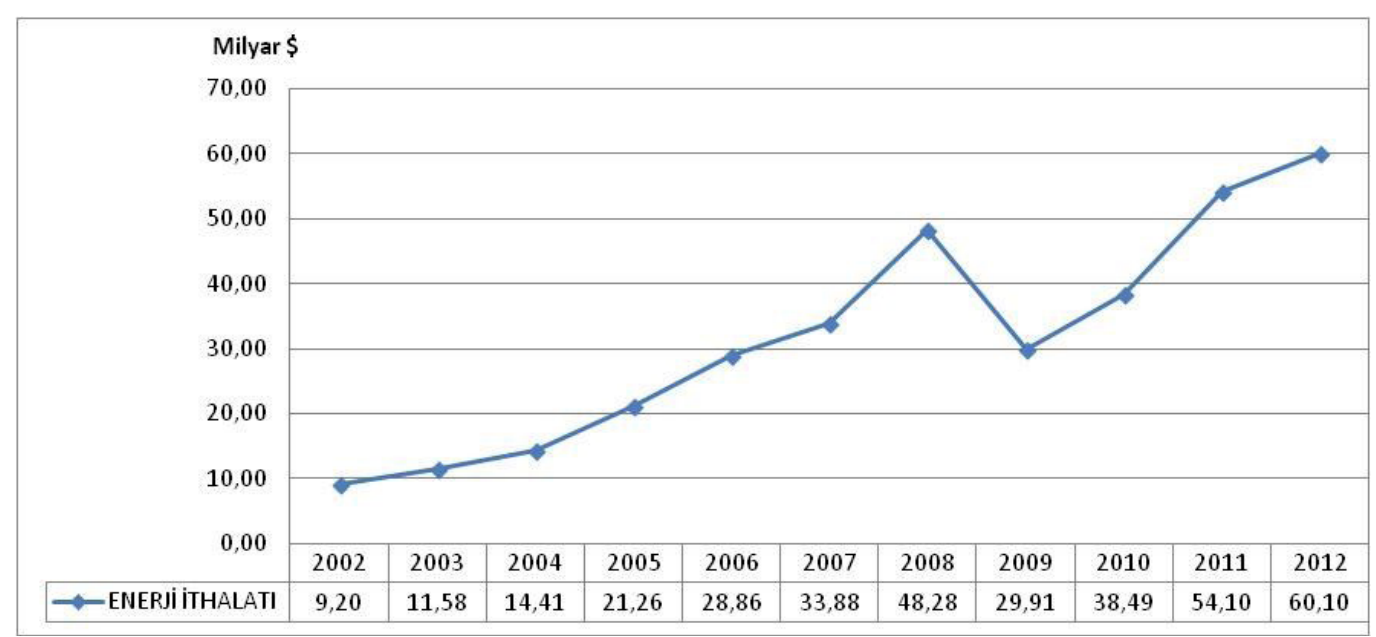

Source: EMRA

Baris Şansli, Deputy Head of Energy Issues Department of MENR lists five factors which can affect Turkish supply security ${ }^{13}$ :

\footnotetext{
${ }^{13}$ Sanli-Nikaz (2013)
} 

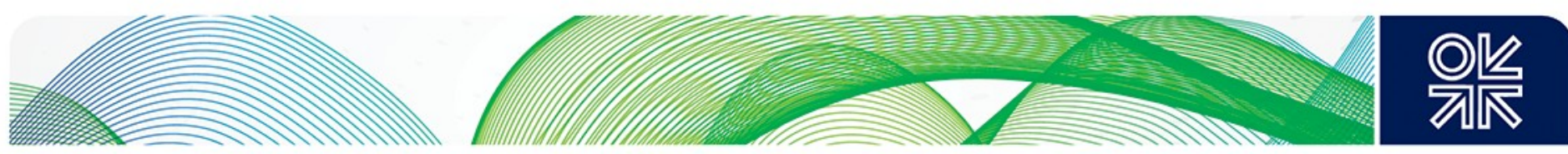

1. Supply sources: Even with an improved internal transportation, system there are not enough supply sources of contracted natural gas;

2. Transportation: Even if there were adequate and diversified gas supply sources, the gas cannot necessarily be physically transferred from an entry point to the point of consumption;

3. High prices. Because of high prices consumers cannot afford natural gas and have to look at alternatives;

4. Contracts. Although prices may seem reasonable, because of speculation or negative expectations and forecasts, market players prefer not to conclude long-term contracts, but insist on short-term agreements, thus increasing uncertainty in the long term;

5. Lack of storage. There may be a shortage of storage volume which restricts withdrawal in timely manner.These factors will be examined in the following sub-sections.

\subsection{Current and Future Contracts}

All the natural gas purchase and sale contracts for the importation of gas intoTurkey were signed with minimum durations of 15 years, based on Turkish natural gas demand forecasts made in the 1990s. 'Take or pay' obligations exist in all the contracts, obliging Turkey to take at minimum a specified proportion of the contracted volume each year, or pay for the gas if it is not taken. Gas not taken in any year can however be taken in a make-up period of $4-5$ years. ${ }^{14}$

BOTAŞ has not been able to take all the contracted volumes, especially from the sources to the east of the country (Azerbaijan and Iran), because of insufficient capacity in the BOTAŞ transmission system, specifically a shortage of compression capacity. BOTAŞ has been able to take almost $90 \%$ of natural gas coming from the Western Line and Blue Stream but overall has had to pay billions of dollars for untaken volumes effectively increasing the price of imports from Azerbaijan and Iran. This problem is under serious scrutiny by the government and some projects to build new compressor stations on the eastern part of the transmission system are underway. One of them is Çayırlı station in the Turkish Province of Erzincan that will enable Turkey to import all the contracted volume from Azerbaijan and Iran.

In the contracts with the SD-I consortium the imported gas price depends on the percentage of gas actually taken: taking all the contracted gas results in a lower price.

\footnotetext{
${ }^{14}$ Deloitte (2012), http://www.deloitte.com/assets/Dcom- 

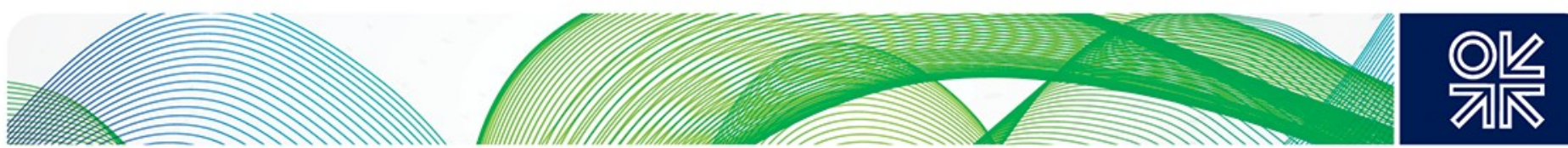

Table 4: Natural Gas Purchase Contracts (2012)

\begin{tabular}{|c|c|c|c|c|c|c|}
\hline Agreements & $\begin{array}{l}\text { Volumes } \\
\text { (During the } \\
\text { Plateau Period) } \\
(\mathrm{Bcm} / \mathrm{y})\end{array}$ & Date of signature & $\begin{array}{l}\text { Duration } \\
\text { (years) }\end{array}$ & $\begin{array}{l}\text { Date } \\
\text { effective }\end{array}$ & $\begin{array}{l}\text { Remaining } \\
\text { Years }\end{array}$ & Status \\
\hline Algeria (LNG) & 4 & 14 April 1988 & 20 & 1994 & 1 & $\begin{array}{l}\text { In operation. } \\
\text { Has been } \\
\text { renewed for } \\
\text { next } 10 \text { years }\end{array}$ \\
\hline Nigeria (LNG) & 1.2 & $\begin{array}{l}9 \text { November } \\
1995\end{array}$ & 22 & 1999 & 8 & In operation \\
\hline Iran & 10 & 8 August 1996 & 25 & 2001 & 13 & In operation \\
\hline $\begin{array}{l}\text { Russian Fed. } \\
\text { (Blue Stream) }\end{array}$ & 16 & $\begin{array}{l}15 \text { December } \\
1997\end{array}$ & 25 & 2003 & 13 & In operation \\
\hline $\begin{array}{l}\text { Russian Fed. } \\
\text { (Western } \\
\text { Line) }\end{array}$ & 8 & $\begin{array}{l}18 \text { February } \\
1998\end{array}$ & 23 & 1998 & 8 & In operation \\
\hline Turkmenistan & 16 & 21 May 1999 & 30 & - & - & - \\
\hline $\begin{array}{l}\text { Azerbaijan } \\
\text { (SD Phase-I) }\end{array}$ & 6.6 & 12 March 2001 & 15 & 2007 & 9 & In operation \\
\hline $\begin{array}{l}\text { Azerbaijan } \\
\text { (SD Phase-II) }\end{array}$ & 6 & 25 October 2011 & 15 & 2018 & - & - \\
\hline
\end{tabular}

Source: BOTAŞ

Figure 11: Turkey's Natural Gas Imports in 2012 by Source Country

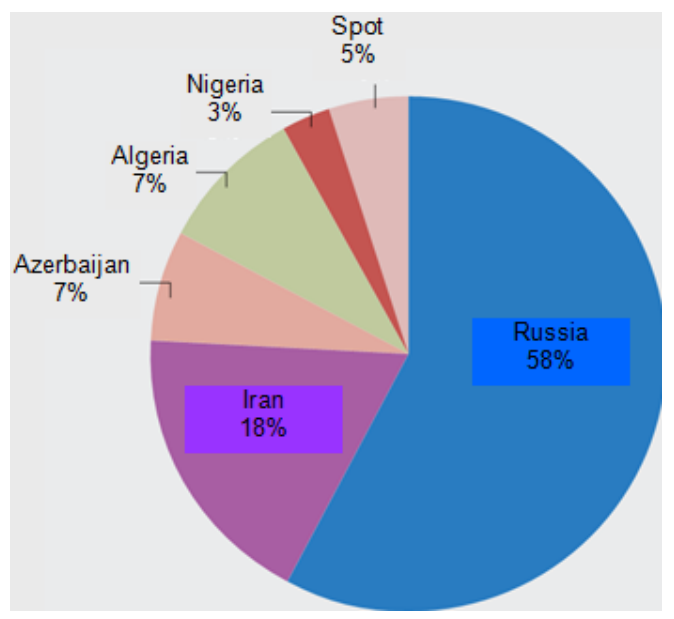

Source: EMRA, Natural Gas Market Sector Report, 2012,

http://www.epdk.gov.tr/documents/dogalgaz/rapor yayin/Ddp yayin rapor 2012.pdf

For the reasons mentioned above, actual import volumes differ from contracted volumes. As shown in Figure 12, the utilization of the LNG import contracts with Algeria and Nigeria $(85 \%$ and $75 \%$ respectively) has been higher than those of long-term contracts.\#

February 2014: Natural Gas in the Turkish Domestic Energy Market: Policies and Challenges 

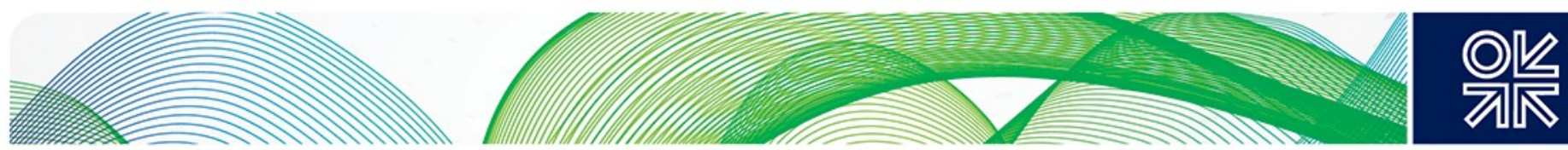

Figure 12: Actual Import Volumes

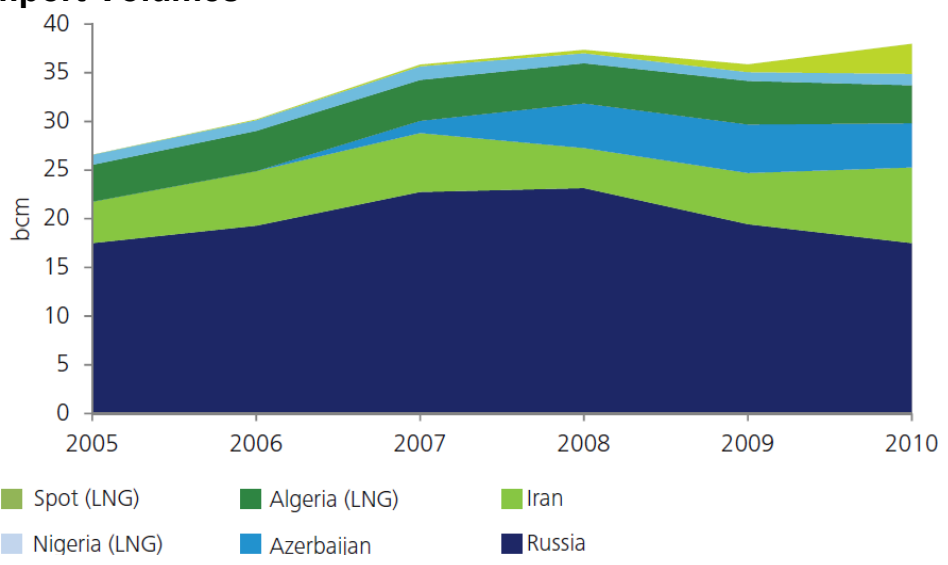

Source: EMRA

BOTAŞ offtake volumes also depend on seasonal demand fluctuations, but although annual actual takes may exceed annual plateau contract volumes, it may not be possible to meet seasonal daily peak demands. This was the case in February 2013 and as a result there was disruption of gas supplies to the Hamitabat and Ambarli power plants.

Chart 4 shows Turkey's daily peak demands for 9 days in December. The maximum daily demand was $196,104 \mathrm{~m}^{3}$, almost twice as high as the minimum daily demand in the summer. Chart 5 shows the corridor between seasonal minimum and maximum demands over time and the expected rapid widening of the corridor to 2019 due to overall demand growth. Defining the coldest expected day in the winter and the corresponding peak demand will enable the government to calculate the necessary volumes of contracted supply during cold days.

The main sectors driving increases in winter natural gas demand consumption in Turkey are electricity generation and the residential sector. 

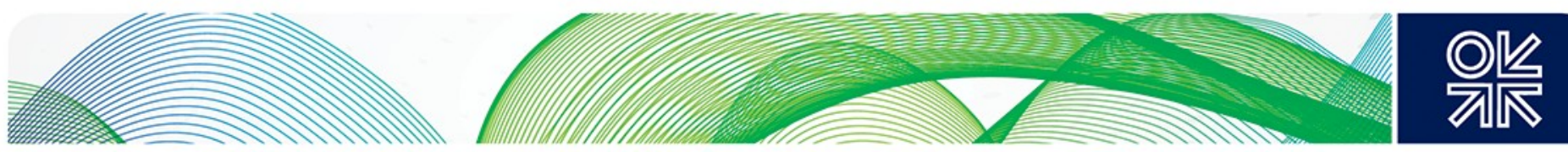

Chart 4: Natural Gas Demand (maximum demand, minimum demand, reference) December 2012

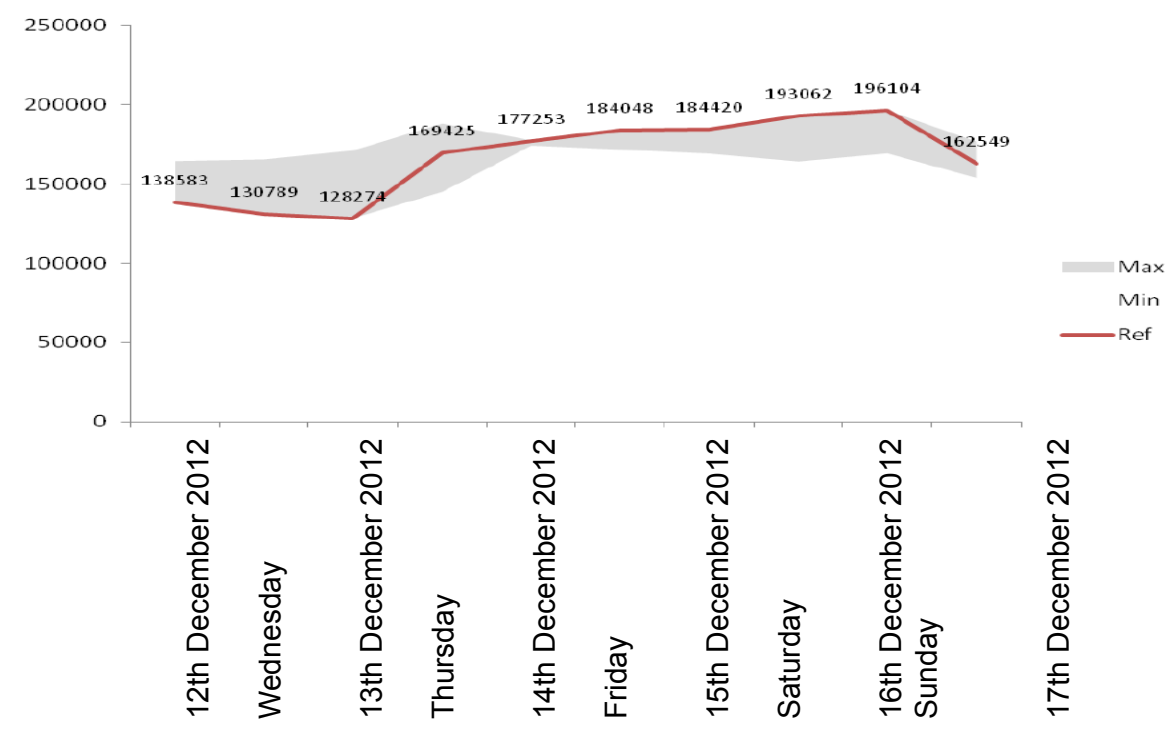

Source: Türkiye'nin Doğalgaz Arz Güvenliği'nin Analitik Bir Değerlendirmes (Analitical Assesment of Supply Security of Turkey), Barış Sanlı, Nadim Ekiz, http://www.barissanli.com/calismalar/2013/bsanlinekiz dogalgaz arz guvenligi-May2013.pdf

\section{Chart 5: Natural Gas Demand Corridor}

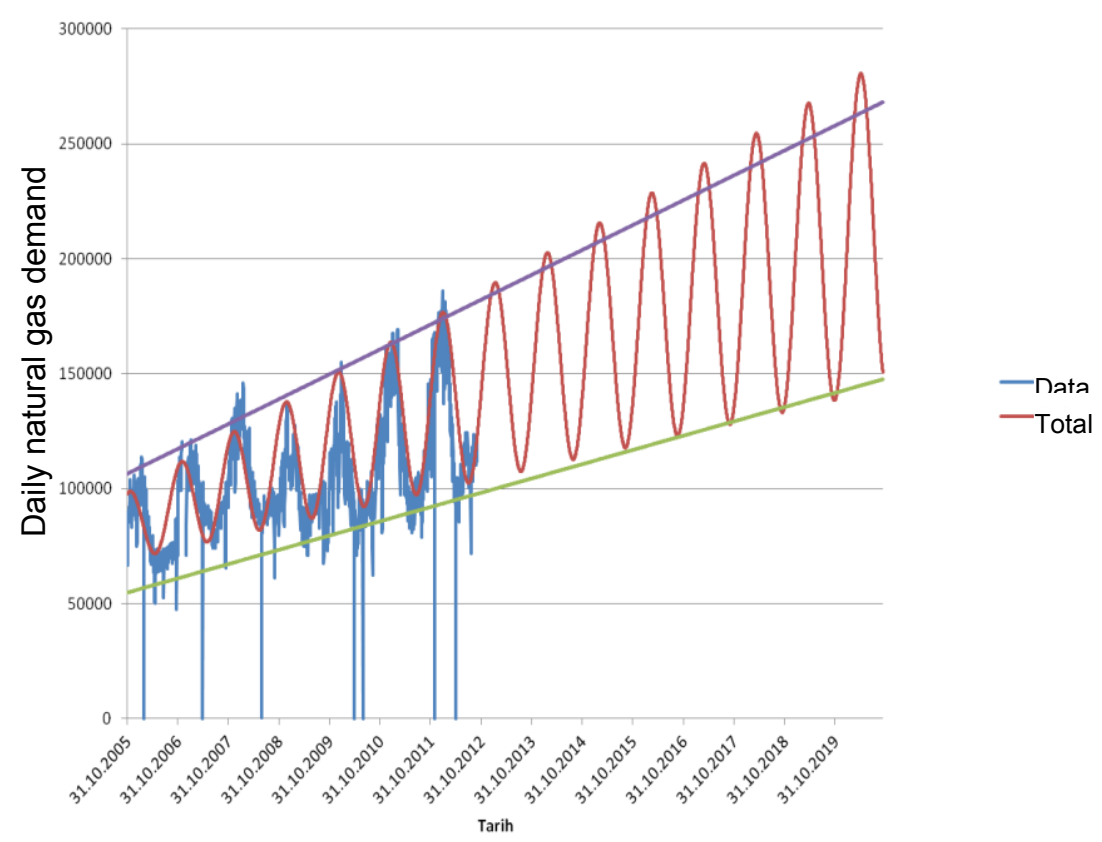

Source: Türkiye'nin Doğalgaz Arz Güvenliği'nin Analitik Bir Değerlendirmes (Analitical Assesment of Supply Security of Turkey), Barış Sanlı, Nadim Ekiz, http://www.barissanli.com/calismalar/2013/bsanlinekiz dogalgaz arz guvenligi-May2013.pdf 

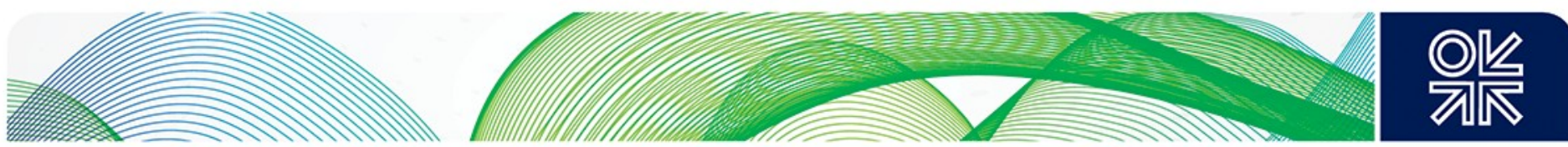

Considering the demand forecast and the development of supply based on existing and future contract plateau levels, it is estimated that Turkey could be in supply deficit from 2015-2018, and also might not be able to meet peak demand during winter days, before SDII gas is exported to Turkey from Azerbaijan. This situation could be worsened if LNG imports are reduced by price pressures and limited regasification capacity. LNG and underground storage will be examined in detail in the next sub-sections.

Figure 13, based on BOTAŞ projections (but excluding spot LNG supplies), shows that, under some circumstances, Turkey could have a $5 \mathrm{Bcm}$ annual supply deficit by 2015 with a corresponding peak deficit, even though Turkey has already renewed its LNG import contract with Sonatrach of Algeria. By 2027, Turkey will need to import an additional $10 \mathrm{Bcm} / \mathrm{y}$, and it is not clear where this volume of gas will come from.

In January 2013, speaking after meeting Turkish Energy Minister Taner Yildiz, Algeria's Energy Minister Youcef Yousfi told reporters that Sonatrach and BOTAŞ had already decided on the conditions and terms of the new supply and purchase agreement. Algeria will deliver $4 \mathrm{Bcm} / \mathrm{y}$ to Turkey for ten years starting in 2014 with the possibility of increasing the volume of gas exported. ${ }^{15}$

Figure 13: Turkey's Supply and Demand Position (Bcm)

\section{TR Natural Gas Supply \& Demand Position (bcm)}

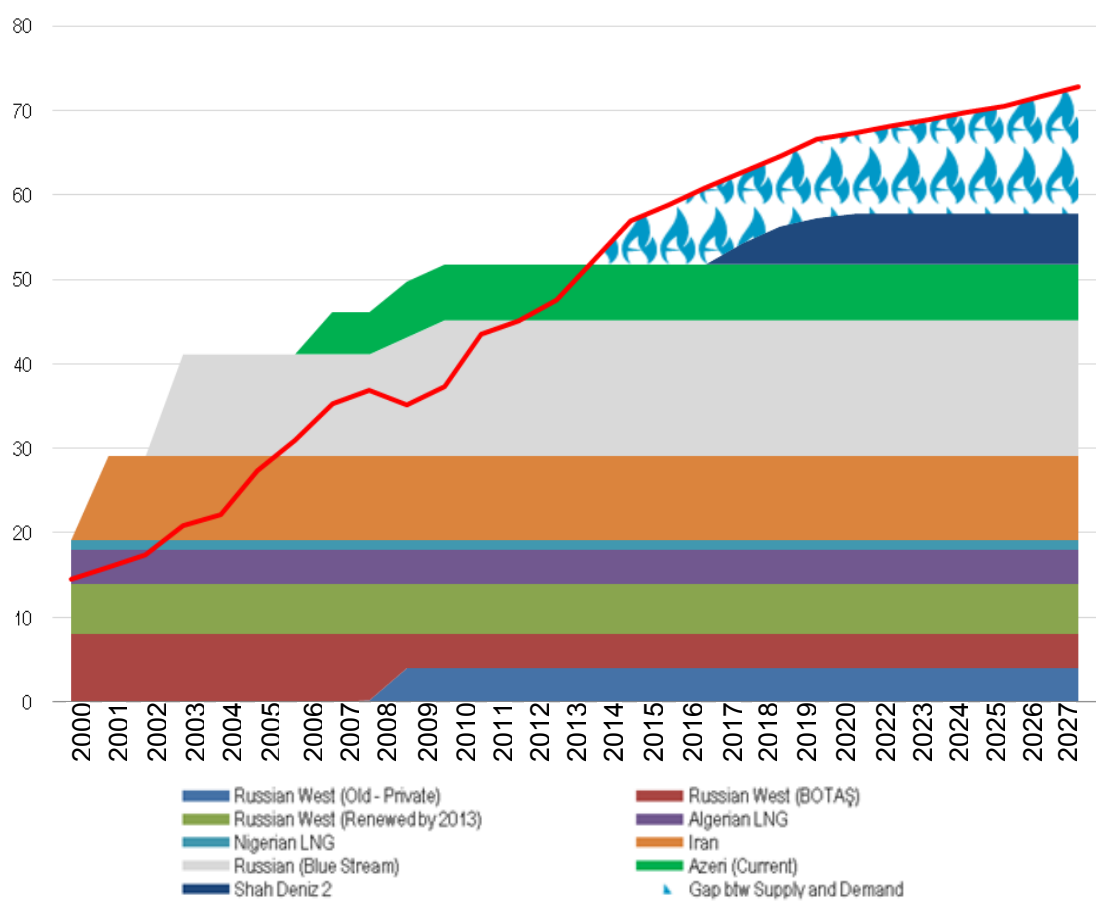

Source: SOCAR Turkey

Note: Demand Projection by BOTAŞ

\footnotetext{
${ }^{15}$ Algeria and Turkey Renew Gas Supply Agreement, http://www.petroleumafrica.com/algeria-and-turkey-renew-gas-supplyagreement/
}

February 2014: Natural Gas in the Turkish Domestic Energy Market: Policies and Challenges 

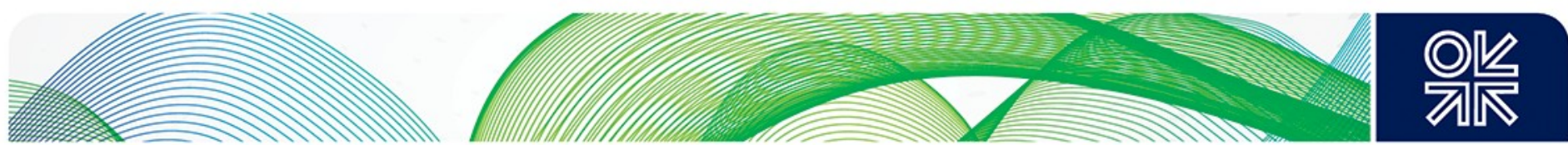

The gap between supply and demand that may open up from 2015 could grow even wider in the 2020 s, if some existing contracts are not renewed. The extension of these contracts mainly depends on the supplier. Russia, for instance, which exports $10 \mathrm{Bcm} / \mathrm{y}$ of gas via the Western Line to private companies, could refuse to renew the contract that expires in 2021. From that date, it would have to sell the gas to companies other than BOTAŞ for a lower price, because those companies are not subsidised by the Turkish government as BOTAŞ is. In 2013 Russia, as well as giving a $4 \%$ discount from the beginning of the year for Turkey, reduced the exported volume by $24 \%$, from $23.15 \mathrm{Bcm}$ in 2012 to $18 \mathrm{Bcm}$ in 2013 (See 5). This was done in line with Turkish government policy to reduce the BOTAŞ share of imports and release gas to private companies, pursuant to the NGML.

SDI as a reservoir will not be exhausted by 2021 . According to publicly available data SDI recoverable reserves are $178 \mathrm{Bcm}$. However the extension of the contract with the SD consortium after 2022 is unlikely to be in place but will be subject to the terms and conditions of the contract that will be negotiated after the expiry of the existing one. Gas from Turkmenistan is not expected to be exported to Turkey in the near future, because of the political problems that prevent it from being transported through Iran, and the lack of infrastructure and political agreement to transport it across the Caspian Sea. This gas may therefore be discounted from Turkey's gas balance. Figure 14, (based on a different BOTAŞ demand projection to that in Figure 13, but including spot LNG) shows the supply deficit in the 2020s.

\section{Figure 14: Natural Gas Supply by Country to 2023}

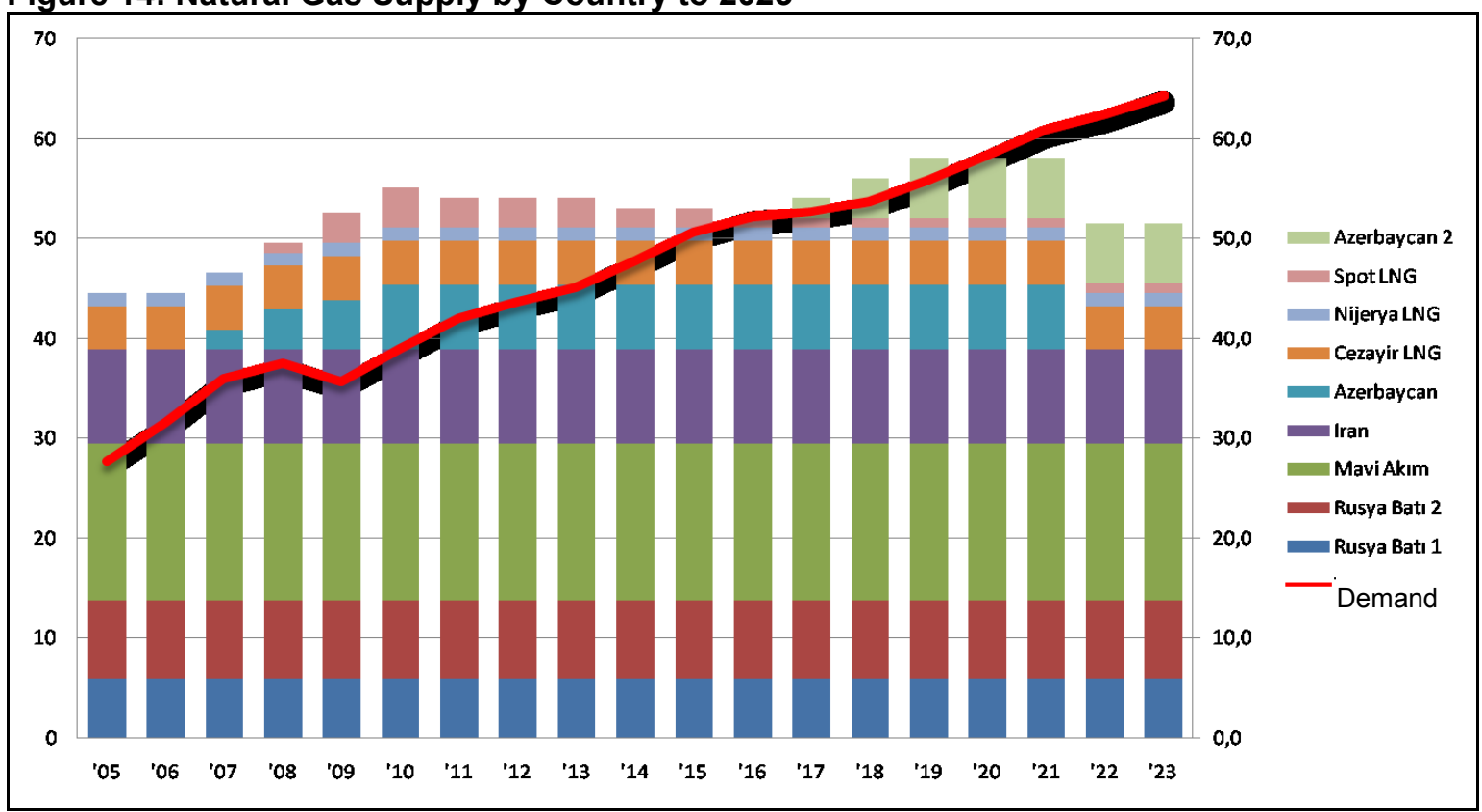

Source: BOTAŞ

However, there are hopes that Turkey will be able to import some additional gas from Azerbaijan's next generation of gas fields - Absheron, Umid/Babek, Shafag-Asiman, Nakhchyvan, Ashrafi and Garabagh - all at various stages of appraisal. These fields are expected to come on stream around 2025and beyond, and could double Azerbaijan's exports to Europe, starting with $10 \mathrm{Bcm}$ from SDII in 2019 and transported to Italy via the Trans-Adriatic Pipeline (TAP). Turkey expects to increase its natural gas imports from Azerbaijan after 2022 at reasonable prices. 

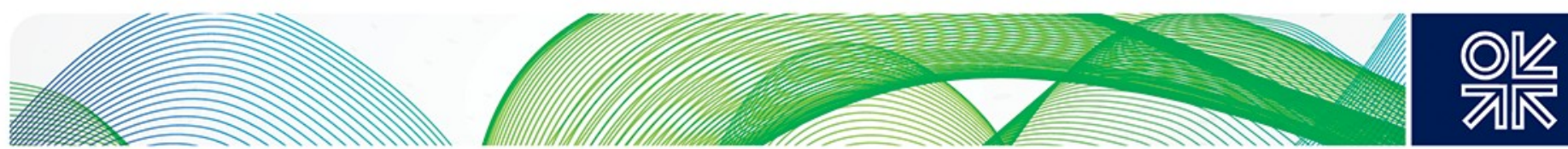

Table 5: Source and Volumes of BOTAŞ Imports (Bcm)

\begin{tabular}{|c|c|c|c|}
\hline Country/Source & 2011 & 2012 & 2013(Estimate) \\
\hline $\begin{array}{l}\text { Russia/Gazprom } \\
\text { Export }\end{array}$ & 21.5 & 23.148 & 18.0 \\
\hline Iran/NIGC & 8.2 & 8.196 & 9.4 \\
\hline Algeria/SONATRACH & 4.2 & 4.219 & 4.3 \\
\hline Nigeria/NLNG & 1.3 & 1.412 & 1.3 \\
\hline $\begin{array}{l}\text { Azerbaijan/Shah } \\
\text { Deniz-I }\end{array}$ & 3.8 & 3.433 & 6.5 \\
\hline Spot & 0 & 0 & 0.6 \\
\hline Total & 39.0 & 40.4 & 40.1 \\
\hline
\end{tabular}

\section{2 'Take or Pay' Obligations}

As was described in the previous sub-section, peak winter consumption is almost twice the level of summer minimum consumption, which is recognised in the "take-or-pay" (ToP) obligation in the Long Term Contracts (LTCs). In some contracts the minimum annual quantities that BOTAŞ must offtake are broken down seasonally (summer/winter or by quarter) and commitments are processed separately for each period. May is the month of lowest consumption and highest ToP risk for BOTAŞ. Annual minimum purchase quantities were complied with until 2007. Moreover, the commisioning of the TPAO underground storage facility at Silivri has made available to BOTAŞ $1.6 \mathrm{Bcm}$ of storage capacity and increased its ability to fulfill its ToP obligation during summer months.

However, BOTAŞ defaulted on its ToP obligation under the Russian and Iranian contracts in 2008, 2009, 2010 and under the SDI contract in 2011 by small quantities. The main reasons were:

- absence of necessary infrastructure,

- the fall in consumption in 2008-2009 due to the global economic crisis, and

- lower consumption of natural gas in gas-fired power plants because high rain levels had enabled hydropower plants to increase their output.

The problems with infrastructure were mainly the failure to complete the $1 \mathrm{Bcm}$ Salt Lake (Tuz Gölu) storage facility and the absence of the necessary installed capacity of compressor stations to move gas from west to east. This problem has now been resolved by the inauguration in August 2013 of the Hanak and Çayırlı high pressure compressor stations in Erzincan on the Azerbaijani and Iranian lines. These will significantly contribute to BOTAŞ's ability to take all the contracted volumes, and BOTAŞ will be able to reduce the SDI gas price under the existing contract which has volume-based incentives. Moreover, the inaguration of the TANAP pipeline project will enable Turkey to transport 6.6 $\mathrm{Bcm}$ of gas from SDII. 

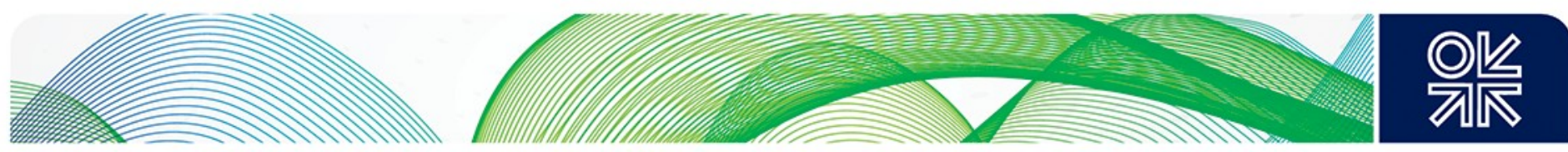

Turkey pays a higher price for Iranian gas than for any other imports, and this is the main reason for rising tensions between two countries. Turkey currently buys Azerbaijani gas for $\$ 349 / 1,000 \mathrm{~m}^{3}$ (without excess volume discount) and paid Russia $\$ 446 / 1,000 \mathrm{~m}^{3}$ until 2012 . However in 2013 Russia applied discounts to its European natural gas customers, including Turkey. For Turkey the discount was $4 \%$ and the price dropped from $\$ 446$ to $429 \$ 11,000 \mathrm{~m}^{3}$. Iran sells its gas to Turkey for $\$ 507 / 1,000 \mathrm{~m}^{3}$, the price agreed after an arbitration process concluded in 2009 in favour of BOTAŞ, with a retrospective price revision within the framework of a discount rate determined by the International Court of Arbitration (a branch of the International Chamber of Commerce (ICC)). The Court awarded Turkey $\$ 800$ million compensation related to the natural gas purchases from Iran. Table 6 illustrates the imported natural gas price for Turkey and discounts in 2013, on the basis of information available from open sources. However according to non-public sources, Turkey pays a slightly lower price for the gas than is indicated in the table.

Table 6: Natural Gas Price for Turkey and Discounts ${ }^{16}$

\begin{tabular}{|c|c|c|c|}
\hline Country & $\begin{array}{l}2012 \\
\left(\text { price } \$ / 1000 \mathrm{~m}^{3} \text { ) }\right.\end{array}$ & $\begin{array}{l}2013 \\
\left(\text { price } \$ / 1000 \mathrm{~m}^{3} \text { ) }\right.\end{array}$ & Discount \% in 2013 \\
\hline Russia (Western Line) & 446 & 429 & 3.81 \\
\hline Russia (Blue Stream) & 445 & 428 & 3.82 \\
\hline Azerbaijan & 354 & 349 & 1.41 \\
\hline Iran & 530 & 507 & 4.34 \\
\hline
\end{tabular}

Source: ZAMAN

In September 2012, BOTAŞ filed a request for the cessation of Iranian gas imports for the fourth time, because of the low gas quality. Although currently Turkey does not have any concerns with supply interruptions and gas quality, the price of Iranian gas remains the highest paid by Turkey. An arbitration process is continuing at the ICC, to reduce the price to European average levels based on the realities of the market.

The high gas sales price and unfulfiled ToP obligations resulting from demand uncertainty continue to be a financial burden for BOTAŞ, costing it billions of dollars. According to a report by Elin Kinnander, Turkey/ BOTAŞ has paid more than $\$ 5$ Billion as take-or-pay penalties ${ }^{17}$ over 1 year only (nearly $\$ 2$ Billion to Iran, $\$ 2.5$ billion to Russia and $\$ 1$ billion to Azerbaijan). The government therefore decided to implement contract and volume releases to the private sector, pursuant to the NGML initiated in 2004 and this was put into practice in 2011 and 2013.

\subsection{Imports by Private Companies}

Companies other than BOTAŞ started importing $4 \mathrm{Bcm} / \mathrm{y}$ of gas from the Russian Western Line in 2011 in line with Article 2 of the NGML on import contract releases. Currently the total import portfolio of private companies in Turkey is $10 \mathrm{Bcm} / \mathrm{y}$, all from the Western Line, and constitutes a 22\% market share. It is most likely that the share of private companies will increase at the expense of BOTAŞ in the mid and long run. Both the current NGML 4646 and new draft amendment, which has not been approved by the national parliament yet, provides for this.

\footnotetext{
${ }^{16}$ Rusya doğalgaza yüzde 8 değil, yüzde 4 indirim yaptı (Russia made 4\% of discount for natural gas import for Turkey, not 8\%), http://www.zaman.com.tr/ekonomi haber-inceleme-rusya-dogalgaza-yuzde-8-degil-yuzde-4-indirim-yapti 2071769.html. Note: The prices given by ZAMAN could be higher than actual prices Turkey pays for the imported natural gas.

${ }^{17}$ Kinnander 2010 ; See also Untangling Turkey's Gas Pricing Knot, http://www.naturalgaseurope.com/high-turkish-energyimports-iran-russia
}

February 2014: Natural Gas in the Turkish Domestic Energy Market: Policies and Challenges 

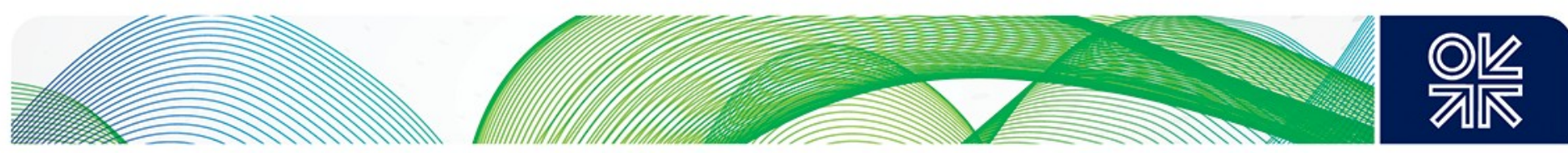

Although the provisional Article 2 of the NGML, dealing with contract and volume releases, was approved in 2004, no contract releases were implemented by BOTAŞ until 2011. The first auction was cancelled in 2004 and Article 2 of the NGML was amended by Law No. 5367 in $2005^{18}$ to allow private companies to import gas directly from the sellers (Gazprom, NIGC, the SD consortium, Sonatrach and NLNG), if they won gas at an auction organised by BOTAŞ, and obtained the consent of the seller. BOTAŞ implements contract transfers but the supplier/s should give its/their consent to sell the gas to companies other than BOTAŞ.

In 2005 BOTAŞ started a new contract release auction, including purchase contracts with Russia, Iran, Nigeria and Algeria. But none of the sellers agreed to sell gas to companies other than BOTAŞ, because of the procedural burden of negotiating with several companies with differing terms and conditions, instead of just one. The seller companies also realised that they would have to sell gas to the private companies at a lower price than to BOTAŞ, because the companies' selling prices to domestic and generation customers would not be subsidised by the government as was the case with BOTAŞ.

Gazprom was the only seller company to agree to sell gas to private companies in 2011, but with some preconditions. The BOTAŞ $6 \mathrm{Bcm} / \mathrm{y}$ contract with Gazprom via the Western Line - Malkoçlar expired at the end of 2011. BOTAŞ gave notice that it would not renew and proposed that private companies could take over the contract in accordance with Article 2 of the NGML. However, it only gave this notice two months prior to the expiration of the contract and the entire 14 million population of Istanbul was at risk of being without gas in the coldest winter months.

EMRA issued its Board decision No. 3476 on October 26, 2011, calling for applications to import natural gas from Gazprom via the Western Line to be submitted by November 23. The maximum contract quantities would be 5 Bcm/y for 2012, 2013 and 2014, and 6 Bcm/y for subsequent years. Although 26 applications for import licenses were submitted to EMRA, Gazprom took advantage of the time pressure on Turkey and did not approve any of the applications from private companies.

A new negotiation process began, but it is interesting that issues of documentation approval for Gazprom's South Stream Project, past ToP defaults by BOTAŞ under the Blue Stream contract, and price revisions, were also included in the negotiations. Agreement on all the issues, including the gas purchase contract was reached by the end of December 2011. Private companies would import 4 $\mathrm{Bcm} / \mathrm{y}$ and BOTAŞ would be able to take $5.6 \mathrm{Bcm} / \mathrm{year}$ of additional natural gas as untaken gas within the ToP obligations from the Western Line by the end of 2012.

The contract transfer process that started in 2007 will continue to reduce BOTAS's share of imports. According to the new version of the NGML, drafted in May 2013 but not yet approved, the transfers will continue until BOTAS's share is reduced to $50 \%$ or lower.

Four companies submitted offers that have been processed by BOTAŞ which offered 16 lots (equivalent to $4 \mathrm{Bcm} / \mathrm{y}$ ) to private companies (lines 1 to 4 in Table 7):

\footnotetext{
${ }^{18}$ NGML (Law to the Amendmend), Law No.: 5367, available at:, http://www.epdk.gov.tr/index.php/dogalgazpiyasasi/mevzuat?id=50 (in Turkish)
} 

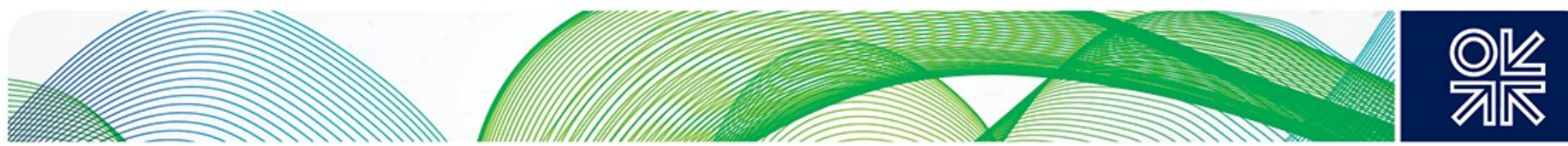

Table 7: First and New Private Companies Contracts (2013)

\begin{tabular}{|c|c|c|c|}
\hline \multirow{2}{*}{\multicolumn{2}{|c|}{ Company }} & \multirow[t]{2}{*}{ (billion $\mathrm{Cm}^{3} / \mathrm{a}$ ) } & \multirow[t]{2}{*}{$\begin{array}{l}\text { Contract Termination } \\
\text { Year }\end{array}$} \\
\hline & & & \\
\hline 1 & Shell & 0.25 & 2021 \\
\hline 2 & Bosphorus Gaz & 0.75 & 2021 \\
\hline 3 & Enerco Enerji & 2.5 & 2021 \\
\hline 4 & Avrasya Gaz A.Ş. & 0.5 & 2021 \\
\hline 5 & Akfel & 2.25 & 2043 \\
\hline 6 & Bosphorus Gaz 2 & 1.75 & 2043 \\
\hline 7 & Kibar & 1 & 2043 \\
\hline 9 & Western Line & 1 & 2036 \\
\hline & TOTAL & 10 & \\
\hline
\end{tabular}

Source: EMRA

After the EMRA and the Competition Authority approved the contract transfers, and BOTAŞ completed the documentation of the purchase contracts for the Western Line, protocols were signed by BOTAŞ, Gazprom Export and the new buyers. Shell signed the first Standard Transportation Contract with BOTAŞ in 2007, giving access to the transmission network in December 2007, and took over the contractual obligations. ${ }^{19}$

\footnotetext{
${ }^{19}$ Shell - the company ranked first in the list was awarded the import license No. 1253-3, dated 12.07.2007, the second company Bosphorus Gaz - No. 1346-2 dated 18.10.2007, the third company, Enerco Energy Industry. ve Tic. A.Ş. - license No. 1924-4 dated 31.12.2008, and the fourth company Avrasya Gaz dated 26.02.2009 and the import license given by the EMRA Board Decision No. 1989-4. Shell started its import and wholesale activity in December 2007, Bosphorus Gaz - on 3 January 2009 and Avrasyagaz Enerco started on 1 April 2009. See EMRA report 2012
} 

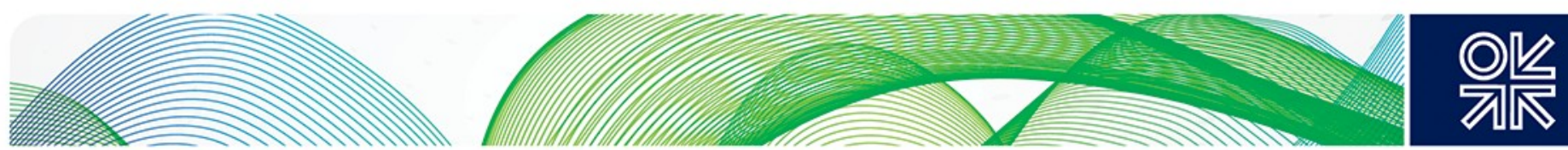

Table 8: Imports by Private Companies

\begin{tabular}{|l|r|r|r|}
\hline $\begin{array}{l}\text { Private Sector } \\
\text { (BCM) }\end{array}$ & $\mathbf{2 0 1 1}$ & $\mathbf{2 0 1 2}$ & $\mathbf{2 0 1 3}$ \\
\hline AVRASYA & 0.5 & 0.4 & 0.5 \\
\hline SHELL & 0.2 & 0.2 & 0.25 \\
\hline BOSPHORUS & 0.7 & 0.5 & 2.25 \\
\hline ENERCO & 1.8 & 2 & 2.5 \\
\hline EGEGAZ & 3 & 0.9 & 0 \\
\hline AKFEL & 0 & 0 & 2.25 \\
\hline Kibar Energy & 0 & 0 & 1 \\
\hline Western Line & 0 & 0 & 1 \\
\hline TOTAL & 6.2 & $\mathbf{4 . 0}$ & $\mathbf{9 . 7 5}$ \\
\hline
\end{tabular}

Source: EMRA

As a result of the contract transfer to private companies, the EMRA decided to terminate $6 \mathrm{Bcm}$ of the BOTAŞ import license from the Malkoçlar Entry Point (Western Line) by April 1, 2012. In order to continue to import this volume, BOTAŞ resubmitted the agreements signed with the 4 private companies for approval by the EMRA, which accepted all the import license applications by private companies in August 2012. EMRA has decided to grant import licenses to Akfel Gas Industry and Trade Joint Stock Company, Bosphorus Gaz Corporation Joint Stock Company, Kibar Energy Distribution Industries Inc., and Batı Hattı Ticaret A.Ş (Western Line) that were willing to import natural gas from the Russian Federation. They started their gas import operations in January 2013 (Table 7, lines 5 to 9 ).

EMRA continues to accept applications from private companies for licences to import natural gas and LNG. The main factor that EMRA takes into consideration is demand forecasts. For example, forecasts showed that imports would exceed demand in 2013 (demand $47 \mathrm{Bcm}$, import $51 \mathrm{Bcm}$ in total), so EMRA declined to grant licenses to import additional volumes of gas by private companies.

\subsection{The Natural Gas Price for Private Companies}

The subsidised natural gas price for households, gas-fired power plants and industry is a commercial barrier for the private companies, preventing them from buying gas for the same price BOTAŞ does and selling it at lower prices. Private companies cannot buy gas from Gazprom Export for the same price as BOTAŞ and make a profit because prices in the domestic market are defined and regulated by the EMRA for BOTAŞ and all other companies.

This price issue was one of the subjects of negotiation with Gazprom Export in 2011 when Gazprom agreed to sell gas to private companies. Gazprom agreed to sell gas to Turkish Natural Gas Importers and Exporters Association (DIVID) member companies for the lower price of $\$ 350 / 1000 \mathrm{~m}^{3}$ in order to be able to sell this gas in the subsidised market. BOTAŞ currently pays $\$ 429 / 1000 \mathrm{~m}^{3}$ after the $4 \%{ }^{20}$ discount Gazprom Export granted in January 2013.

\footnotetext{
${ }^{20}$ Rusya doğalgaza yüzde 8 değil, yüzde 4 indirim yaptı (Russia made 4\% discount for natural gas import for Turkey, not $8 \%$ ), http://www.zaman.com.tr/ekonomi haber-inceleme-rusya-dogalgaza-yuzde-8-degil-yuzde-4-indirim-yapti 2071769.html
}

February 2014: Natural Gas in the Turkish Domestic Energy Market: Policies and Challenges 

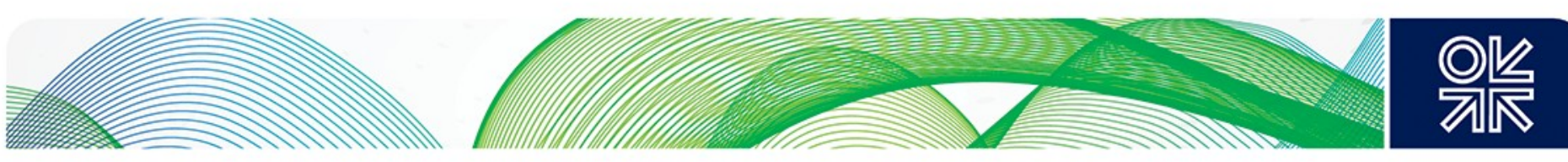

According to EMRA, natural gas prices for residential customers are determined quarterly on January 1 , April 1 , July 1 and October 1 . The price formula is based on the current purchase price of natural gas, the purchase price (base price) of natural gas for the agreement period, the past 6-9 months' average prices of oil products used in the formula and the prices of products used in fixed term agreements reached. Changes in foreign currency for the domestic market also play an important role in determining the prices.

Table 9 shows the volumes of imports by private companies, amounting in 2013 to just under to 10 $\mathrm{Bcm} /$ year or $25 \%$ of total Turkish imports. Because of the risk that Gazprom may stop selling gas for a special price of $\$ 350 / 1000 \mathrm{~m}^{3}$ instead of the BOTAŞ price $-\$ 428 / 1000 \mathrm{~m}^{3}$ some of them have gone into partnership with Gazprom. For instance Akfel has merged with Gazprombank (Akfel 60\%, Gazprombank 40\%; Gazprom Germania has a 75\% share in Bosforus Gaz; Gazprombank has 60\% of Avrasiya Gas with Tahincioglu (40\%) (see Table 9).

Table 9: The Share of Private Companies in Overall Natural Gas Import into Turkey, 2013

\begin{tabular}{|l|l|l|}
\hline Company name & volume (bcm/y) & $\begin{array}{l}\text { Ownership of private } \\
\text { companies }\end{array}$ \\
\hline $\mathbf{1}$ & $\mathbf{2}$ & $\mathbf{3}$ \\
\hline Akfel Gaz & 2.25 & Akfel Group - 100\% \\
\hline Enerco Energy & 2.5 & $\begin{array}{l}\text { Akfel Group - 60\% } \\
\text { OMV Gas \& Power - 40\% }\end{array}$ \\
\hline Bosphorus Gaz & 2.25 & $\begin{array}{l}\text { Germania Gazprom - 75\% } \\
\text { Tur Enerji - 29\% }\end{array}$ \\
\hline Shell Enerji Türkiye & 0.25 & Royal Dutch Shell - 100\% \\
\hline Avrasya Gas & 0.5 & $\begin{array}{l}\text { Prima Energy Trading - 60\% } \\
\text { (Gazprombank) } \\
\text { Tahincioğlu - 40\% }\end{array}$ \\
\hline Batı Hattı & 1 & $\begin{array}{l}\text { EKSiM Investment Company - } \\
60 \% \text { (EKSIM Group) } \\
\text { BIM - 40\% }\end{array}$ \\
\hline Kibar Enerji & 1 & Kibar Holding - 100\% \\
\hline & 9.75 & \\
\hline
\end{tabular}

Source: Official websites of the companies

\subsection{LNG Imports}

In 2012 Turkey's overall LNG import was $7.8 \mathrm{Bcm}$ including spot LNG; LNG imports were $17 \%$ of pipeline gas by volume. Of the total LNG imports, $31 \%$ was spot gas imported by BOTAŞ and private companies. In 2012 BOTAŞ imported 5.6 Bcm of LNG from Algeria and Nigeria and $640 \mathrm{Mmcm}$ of spot LNG. Turkey has only 2 LNG terminals - Marmara Ereğlisi, and Egegas Aliaga with total LNG storage capacity of $1.5 \mathrm{Bcm}$. 

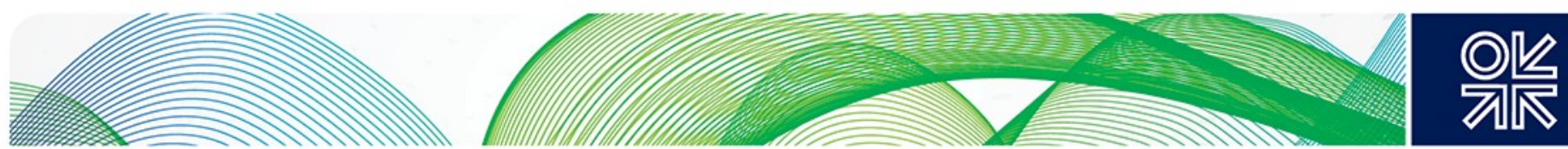

Table 10: Storage Operations Facility Information (2012)

\begin{tabular}{|l|l|l|l|}
\hline Company & $\begin{array}{l}\text { Facility } \\
\text { Type }\end{array}$ & Facility Location & Storage Capacity \\
\hline BOTAŞ & LNG & $\begin{array}{l}\text { Marmara Ereğlisi } \\
\text { Tekirdağ }\end{array}$ & $255,000 \mathrm{~m}^{3}$ LNG $\left(85,000 \mathrm{~m}^{3} \times 3\right)$ \\
\hline Ege Gaz A.Ş. & LNG & Aliağa / Izmir & $280,000 \mathrm{~m}^{3}$ LNG $\left(140,000 \mathrm{~m}^{3} \times 2\right)$ \\
\hline TPAO & Storage & Silivri / Istanbul & $2,661,000,000 \mathrm{~m}^{3}$ \\
\hline BOTAŞ & Storage & Sultanhanı / Aksaray & $1,500,000,000 \mathrm{~m}^{3}$ \\
\hline
\end{tabular}

Source: Natural gas Market Sector Report 2012, EMRA, Available in Turkish at: http://www.epdk.gov.tr/documents/dogalgaz/rapor yayin/Ddp yayin rapor 2012.pdf

To diversify supply sources by improving the security of supply and flexibility of procurement, BOTAŞ has built up experience in the LNG business since the 1980s. It has bought spot LNG on a tender basis from as far away as Australia but mainly from Qatar and partly from Abu Dhabi. The MarmaraEreglisi LNG import and re-gasification terminal was built in the 1980s in the Marmara Sea.

Figure 15: Share of LNG Imports in 2012 by Source Country

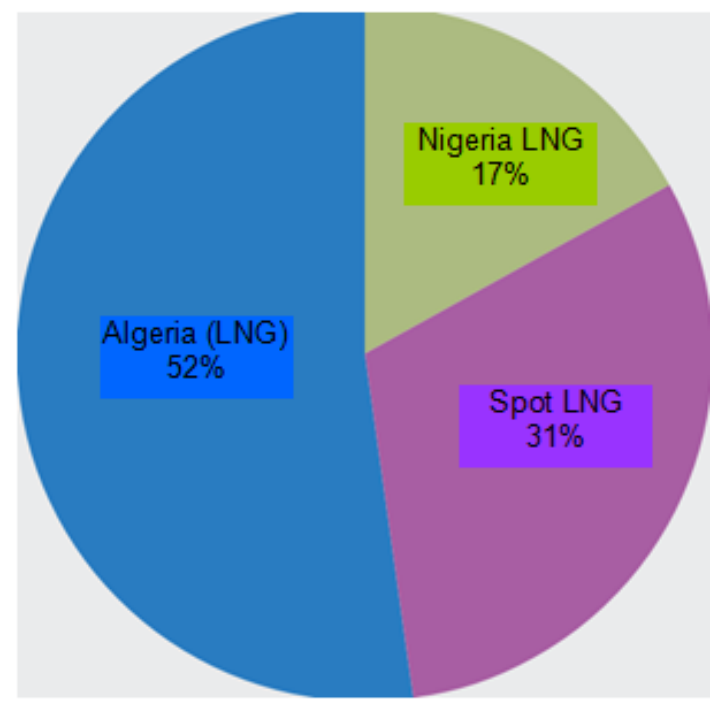

Source: Natural gas Market Sector Report 2012, EMRA, Available in Turkish at: http://www.epdk.gov.tr/documents/dogalgaz/rapor yayin/Ddp yayin rapor 2012.pdf

BOTAŞ in 1988 signed a 20-year SPA with state-owned Sonatrach of Algeria to buy $2 \mathrm{Bcm} / \mathrm{y}$ of natural gas equivalent of LNG. This volume was increased to $4 \mathrm{Bcm} / \mathrm{y}$ in 1995. It was able to absorb this volume until the recession in late 2001 caused demand for natural gas in Turkey to fall sharply below the BOTAŞ SPA commitments in 2002 through 2004. 

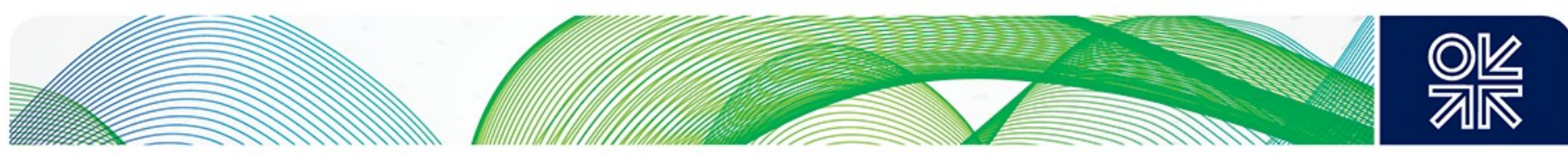

In 1995, BOTAŞ and Nigeria's NLNG signed a 20-year SPA for the supply of $1.2 \mathrm{Bcm} / \mathrm{y}$. This also became a burden on BOTAŞ because it could not absorb the contract volume, and is committed by a ToP clause. In 2005, however, BOTAŞ managed to find short-term buyers for the surplus LNG through trading contracts.

Turkey has suffered from supply deficits in the past as a result of reductions in the natural gas supply through the Western Line during the natural gas supply disruptions between Russia and Ukraine in 2006 and 2009; cut-backs in natural gas exports from Iran in winter months due to technical problems; and the lack of sufficient storage capacity in Turkey itself.

The Turkish government is planning to cover the supply deficit with long-term LNG contracts, but also spot LNG cargoes. BOTAŞ agreed to renew its long-term LNG contract with Algeria in January 2013 and there is an existing contract with Nigeria. No new long term LNG or spot LNG contracts are in place yet.

The two LNG terminals in Turkey - EGEGAS in Izmir-Aliaga owned by Egegas A.S. and the Marmara Ereglisi LNG terminal owned and operated by BOTAŞ, have total storage capacity of $280,000 \mathrm{~m}^{3}$ (two storage tanks) and $255,000 \mathrm{~m}^{3}$ respectively. The annual maximum re-gasification capacity of Marmara Eriglisi is $8.2 \mathrm{Bcm} / \mathrm{y}$, and a maximum of $22.05 \mathrm{Mmcm} /$ day of regasified LNG can be shipped into the transport system. The annual maximum re-gasification capacity of Egegas Aliaga is $6 \mathrm{Bcm} / \mathrm{y}$, and the terminal has facilities to fill overland tankers.

Egegas Aliaga has been mainly used as back up gas to meet peak consumption during cold winter days, and to offset interruptions or reductions in natural gas supply from the Western line, and the risks of the closure of the Dardanelles for traffic in the event of of strong storms. BOTAŞ imports 5.2 $\mathrm{Bcm} / \mathrm{y}$ of LNG from Algeria $(4 \mathrm{Bcm} / \mathrm{y})$ and Nigeria $(1.2 \mathrm{Bcm} / \mathrm{y})$ and additionally from 2013 began importing spot LNG. Apart from dispatch to the transport system through re-gasification, there is a significant amount of LNG dispatched through overland tankers.

According to Article 5 of the NGML 4646, in order to enable private companies to import both pipeline and LNG gas, BOTAŞ cannot sign a new contract with the countries where it already has a contract. However, through Law No. 5784 dated July 92008 on the Amendment of the Electricity Market Law and other Laws ${ }^{21}$, BOTAŞ has the right to enter into new contracts for LNG imports (e.g. the LNG contract with Algeria), while allowing private companies to import spot LNG. Spot LNG import was not regulated by the EMRA prior to this Amendment and was effectively a gap in the Law. The Amendment included import of spot LNG and also enabled private companies to import from multiple countries through one import license.

Virtual trading has increased since 2011, and some import and wholesale companies have asked BOTAŞ to arrange gas swaps. BOTAŞ has only agreed to one swap, when supplies from the Western Line were interrupted in April 2009 and four private importers could not meet their demands. Supplies available from other sources were sufficient to meet the demand, and BOTAŞ temporarily sold natural gas to these 4 companies via UDN - the Turkish hub (see section 4.2 below). The spot market price in Turkey similar to the price on NBP.

\footnotetext{
${ }^{21}$ NGML 4646 (Law to the Amendment), Law No.: 5784. Available in Turkish at: http://www.epdk.gov.tr/index.php/dogalgazpiyasasi $/ \mathrm{mevzuat?id=50}$
}

February 2014: Natural Gas in the Turkish Domestic Energy Market: Policies and Challenges 

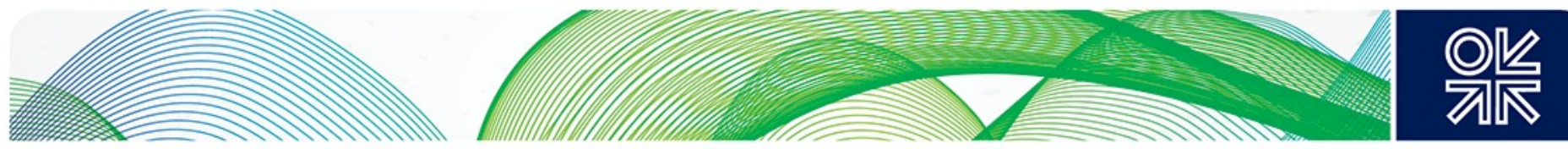

Figure 16: Private Sector Virtual Trade vs. Offtake Volumes and Market Share

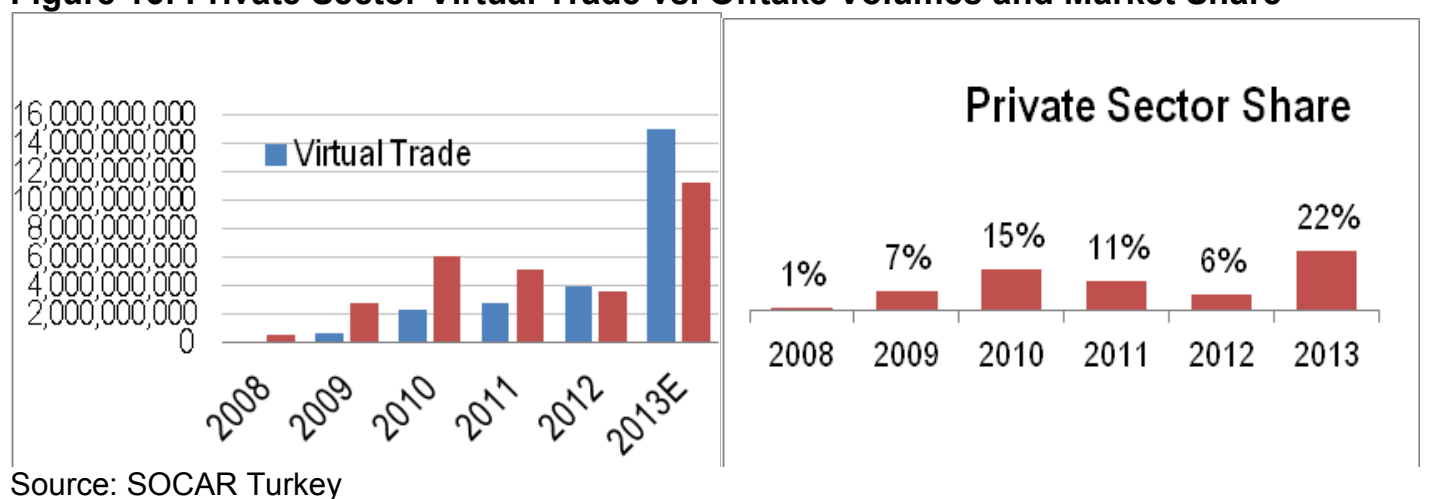

Source: SOCAR Turkey

The EMRA first published the 'Regulation on Basic Principles and Procedures Applicable to the Use of Liquefied Natural Gas Facilities' in 2009 within the framework of the Principles of Fully Open Access for third parties and the draft 'Principles and Procedures of Use' (PPU) for two LNG Terminals in Turkey ${ }^{22}$. The document came into force prior to the Council of Ministers decision dated June 3 2010, and after that both Egegas and BOTAŞ started regularly publishing monthly reserves and available capacities for both terminals. However, PPU does not include any provision regarding the portion of daily re-gasification capacity of Marmara Ereglisi to which BOTAŞ has absolute priority access, which is a factor of crucial importance for the private companies.

The third party access rules applied to Egegas are set out in the 'EgegasAliaga LNG Terminal Basic Principles and Procedures of Use ${ }^{, 23}$ (PPU). They have a very similar structure to those for the BOTAŞ LNG terminal and include similar provisions. The only difference between the two documents concerns third party access. Priority has been granted to BOTAŞ regarding capacity utilization at Marmara Ereglisi LNG Terminal based on the BOTAŞ long-term LNG purchase contracts until the BOTAŞ unbundling process is completed. The same provision has not been applied to Egegas, which did not have any long-term LNG import contracts before the publication of the NGML. ${ }^{24}$ Based on the terminal service contract, which BOTAŞ signed to get access to the Egegas terminal, BOTAŞ is using this terminal along with Egegas. There is no indication of any exemption in the NGML and this can be considered as a gap in the Law.

Although 32 companies had obtained spot LNG import licenses from the EMRA by the end of 2012, just a few were able to buy spot gas. During 2012 only 2 companies (BOTAŞ and Egegas) have imported spot LNG and sold it in the domestic market. Although BOTAŞ made public the reserved and available capacities of the Marmara Ereglisi terminal on a regular basis, no third party has received service and reserved capacity at the terminal. This can be explained by the obstacles provided by the provision of the NGML requiring importers to to store $10 \%$ of their import volumes in the first five years, which increases the entry cost for private companies.

Chart 6 shows that the volume of LNG imports fell in 2011 and 2012 and was only $14.8 \%$ of natural gas consumption in 2011 compared with 21.5\% (3.075 Bcm) in 2010.

\footnotetext{
${ }^{22}$ The EPDK, Turkish Energy Market: An Investor's Guide 2012, pp.39,

http://www.epdk.gov.tr/documents/strateji/rapor_yayin/yatirimciel_kitabi/Sgb_Rapor_Yayin_Yatirimciel_Kitabi_Eng_2012_Mb3J G91tFh1B.pdf

${ }^{23}$ Turkish Energy Market: An Investor's Guide 2012

${ }^{24}$ Deloitte (2012 (p. 37), http://www. deloitte.com/assets/Dcom-

Turkey/Local\%20Assets/Documents/turkey tr energy naturalgas 030512.pdf
}

February 2014: Natural Gas in the Turkish Domestic Energy Market: Policies and Challenges 

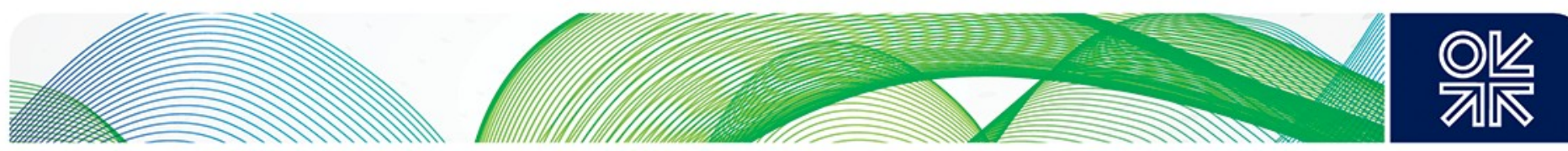

\section{Chart 6: The share of LNG Consumption in the National Natural Gas Consumption}

(2008-2012, \%)

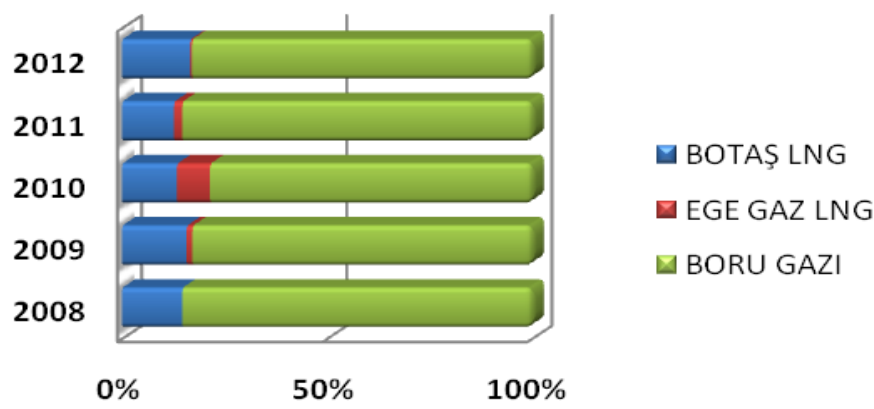

Source: EMRA

Turkey imported more LNG in 2010 because of the low LNG price on the international market, compared with the price of long-term pipeline gas. This was driven mainly by more availability of LNG in the European market prior to the Fukushima disaster in Japan, which led to LNG price increases in 2011 and 2012 and higher insurance and tanker costs. According to the World Bank Commodity Price Data, the annual average LNG price in 2010 was $\$ 10.8 / \mathrm{Mmbtu}$ - the lowest in the last 4 years. The price increased to $\$ 14.7 / \mathrm{Mmbtu}$ in 2011 , to $\$ 16.6 / \mathrm{Mmbtu}$ in 2012 and was $\$ 16.1 / \mathrm{Mmbtu}$ in June 2013. ${ }^{25}$

US production of unconventional gas (shale gas) led it to reduce radically its imports of LNG in the last decade. This coincided with the commissioning of new LNG export volumes from countries such as Qatar. The prospect of the US becoming a major LNG exporter after 2015 could become a driver for an LNG price fall in the period 2015 - 2020. Some companies such as Fenosa, Total and BG Group have already signed gas purchase and sales agreements to import $5-6 \mathrm{Bcm} / \mathrm{y}$ starting from 2016 at a price of $\mathrm{HH}+6$ (Henry Hub price $+\$ 6$ including all costs). Gazprom's contracts with European buyers will expire before 2022-2023 and it expects to negotiate their prolongation with the same volumes or greater. As the largest gas supplier to Europe, it sees the arrival of US LNG in its traditional market as a threat to its market share. Consequently, Gazprom could make significant discounts to its European consumers and offer natural gas for a price lower than the US LNG price for instance $\mathrm{HH}+\$ 5$ - which would make US LNG less attractive and encourage US companies to send LNG to the Asian market instead where the LNG price is currently $40 \%$ higher than in Europe. Thus, the US may indirectly establish a new competitive benchmark around the world. This does not mean that other countries will adopt the same pricing system but they may have to compete or correlate with this system.

Turkey is well positioned to accept LNG from the Atlantic Basin, MENA and Pacific suppliers having an access to the Mediterranean Sea, and could maximise this benefit to import large volumes of LNG. However, the country has constrained capacity of both import terminals and storage, and needs to invest in new terminals and storage capacity, as well as expanding existing infrastructure. A fourth tank is currently under construction by BOTAŞ at the Marmara Ereglisi LNG Terminal, which will add some $140,000 \mathrm{Mm}^{3}$ to the current $280,000 \mathrm{Mm}^{3}$ capacity. Three private companies have also obtained licenses to construct new LNG Terminals at Izmir and Ceyhan each with 6-8 Bcm of capacity, but it seems doubtful that investment decisions will be taken if the sponsors do not obtain an exemption to use the terminal capacity.

\footnotetext{
${ }^{25}$ World Bank Commodity Price Data,

http://siteresources.worldbank.org/INTPROSPECTS/Resources/334934-1111002388669/8293921357588777389/Pnk 0713.pdf
} 

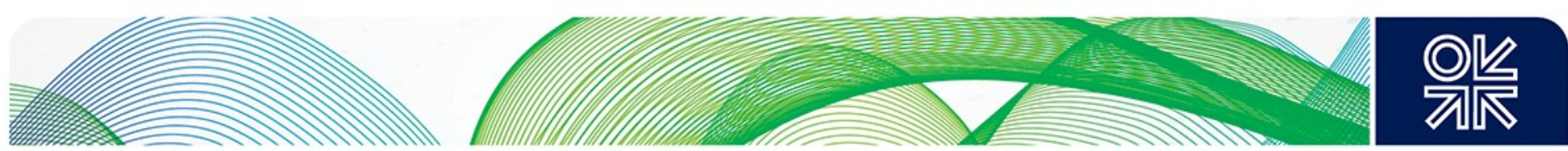

\subsection{Iraq}

Turkey has made attracting gas imports from the Kurdish autonomous region of Iraq a strategic priority. Considerable progress has been made on projects aimed at starting up such imports, although there are still political obstacles to overcome, suggesting that imports are not likely to start until 2020.

The Energy Information Administration (EIA) of the US Department of Energy estimates that Iraq has the $12^{\text {th }}$ largest natural gas reserves in the world $-3.2 \mathrm{Tcm}$ accounting for $1.67 \%$ of world reserves ( $71 \%$ associated gas, $20 \%$ non-associated gas and $9 \%$ condensate gas). Proved natural gas reserves have remained virtually unchanged since around 1990 . Geographically those reserves are spread throughout the country: around $1.0 \mathrm{Tcm}$ is located in the northern area under the control of the Kurdish Regional Government (KRG) and around 2.1 Tcm in the middle and south of Iraq.

Iraq's probable natural gas reserves are estimated between 7.5 and $8.5 \mathrm{Tcm}$ including new sources in the western desert. Additional estimated undiscovered gas resources of 3.1 to $9.2 \mathrm{Tcm}$ may be present in the form of associated gas.

According to the IEA report on Iraq in the central scenario, natural gas exports start around 2020 with $20 \mathrm{Bcm} / \mathrm{y}$. These volumes could comprise exports of pipeline gas to Europe and Turkey or LNG to the Asian markets via future Turkish LNG facilities ${ }^{26}$ (for instance at Ceyhan). However, the availability of export gas will be affected by Iraq's choice of its fuel mix for power generation, which may change over time as electricity generation infrastructure develops.

There are mainly European (French, Austrian, Hungarian and Russian) and US companies investing in the upstream oil and gas fields in Iraq. Turkish TPIC (affiliated with BOTAŞ) and Anglo-Turkish Genel Energy are competing with those companies for the development of the Iraqi natural gas fields. However, the existing disputes between Baghdad and Erbil over hydrocarbon development strategy concerning who has the authority to sign contracts, the basis for revenue sharing, as well as the future of Kirkuk and territorial disputes - make it difficult for Turkey to invest in the Iraqi upstream and plan for natural gas imports with any certainty. One of the major problems is related to Iraqi Kurds who find the monopolization of power in Baghdad around Iraqi Prime Minister Maliki unacceptable, whereas Baghdad wants to bring the Kurdish Regional Government more under the central government's control.

Due to these political constraints and the absence of a national law on exploration and energy transport in Iraq, Turkey cannot come to an agreement with either government to sign contracts. Turkey definitely would like to have access to the rich oil and a natural gas field not only in KRG but also in the rest of the country and for that Turkey's current energy policy towards Baghdad and Erbil is to offer incentives to both capitals to satisfy their expectations. Within this context, the remarks by Turkish Energy and Natural Resources Minister Taner Yildiz at a meeting with KRG President Massoud Barzani in St.Petersburg on June 202013 were significant. Yildiz said that oil and gas production increases should not only be within the framework of KRG decisions, but that: "The Iraqi administration and all Iraqi people should decide together." ${ }^{27}$ Turkey has suggested that the KRG and Iraq should arrange for a fair and constitutional revenue share from the exploration of oil and gas fields. Also, oil and gas production should be transported via Turkey to the international markets including Europe.

Turkey's main hope is to import gas from Kurdistan rather than southern Iraq. Kurdistan could start to ship gas into Turkey by 2015-16 if the political issues are solved, and the Akkas (non-Kurdish) region

\footnotetext{
${ }^{26}$ IEA (2012)

${ }^{27}$ Energy touches 'all of Iraq': Minister, Huriyyet Daily News, June 22 2013, http://www.hurriyetdailynews.com/energy-touchesall-of-iraq-minister. aspx?page $\mid \mathrm{D}=238 \&$ nI $\mathrm{D}=49241 \&$ NewsCat $\mid \mathrm{D}=348$
}

February 2014: Natural Gas in the Turkish Domestic Energy Market: Policies and Challenges 

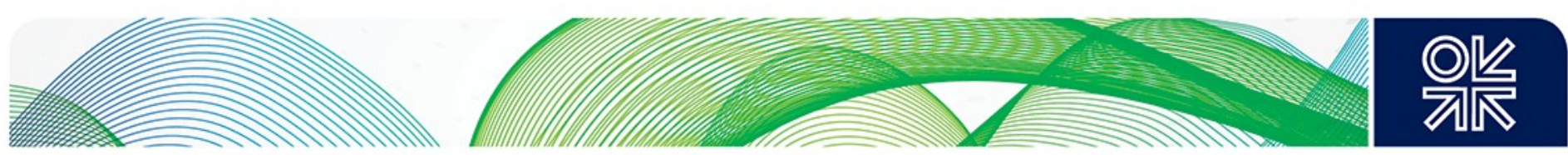

is moderately likely to be able to deliver gas a few years later via the AGP (Arab Gas Pipeline) to Turkey. Akkas is located in Anbar province (close to the Iraqi-Syrian border) with potential reserves of over $178 \mathrm{Bcm}$. However, the political turmoil in Syria is likely to delay this development.

For Turkey, contracting pipeline gas from Northern Iraq is the priority. As the distance is not great, some Turkish private companies are ready to import gas from Iraq to Turkey in accordance with Article 5 of the NGML. Also, a natural gas pipeline could give Turkey a foothold in the region's energy industry.

On August 15, 2008 UAE'S Crescent announced it was teaming up with Turkey's Turkerler to form a joint venture import project called Inci Gaz. Initial volumes of $3.5 \mathrm{Bcm} / \mathrm{y}$ were expected to flow from Iraq from 2011, possibly increasing to more than $10 \mathrm{Bcm} / \mathrm{y}$. The Inci Gaz companies plan to make the necessary infrastructure investments to transport and supply the natural gas to the Turkish market and potential foreign consumers. However the project has not been realized due to the political tensions in Iraq.

Also, in 2008 , there was a plan to complete feasibility studies for a Turkey-Iraq natural gas pipeline project in the shortest possible time, and executives from Iraq and Turkey signed framework agreements for the construction of the pipeline, to be carried out by a consortium of TPAO, Tekfen and BOTAŞ. Around $10 \mathrm{Bcm} / \mathrm{y}$ of natural gas obtained from five areas in Iraq was to be transported to Turkey. The pipeline was to follow the Silopi, Sirnak and Diyarbakir route into Turkey.

The most recent candidate to arrange natural gas exports from Northern Iraq into Turkey is Genel, the largest producer in Iraq's Kurdish region. Genel, ExxonMobil and DNO are among companies caught up in disputes between the Iraqi administrations over the right to control contracts, territorial claims and crude oil revenues. According to Genel it is talking to four Turkish utilities about selling gas from its Miran field (3.8Tcf of recoverable resources and 90MMbbl of oil). In February 2013, the company announced plans to boost the Taq Taq field's capacity to 200,000bbl/y. A gas pipeline joining Taq Taq in Northern Iraq with the Iraq-Turkey Pipeline at Fishkabur is being built. It is expected to reach the town of Dohuk about $40 \mathrm{~km}$ from the Turkish border in the second quarter of 2014.

According to Turkish Energy Minister Taner Yildiz, Turkey has informed the Iraqi government that it is ready to build new pipelines to transport oil and gas from Kurdistan. Additionally, during the meeting of Turkish and KRG Prime Ministers Recep Tayip Erdogan and Nechirvan Barzani in Ankara in March 2013, the Turkish side suggested building new pipelines through the corridor from Kirkuk, among them a natural gas pipeline.The proposed KRG-Turkey gas pipeline is almost ready. Both are considering import into Turkey in 2014 already. According to recent anecdotal information Istanbulbased Siyahkalem Engineering Construction Industry and Trade was issued a first Kurdish gas import license by the EMRA, valid for 26 years. It is expected that the company will start importing 700 $\mathrm{MMcm}$ in 2014 , which will expand to $3.2 \mathrm{Bcm}$ by $2033 .{ }^{28}$ Currently Ankara is trying to mediate between Baghdad and Erbil to find a political solution, which is highly likely.

One piece of the solution is for Turkey to build gas-fired power plant with capacity of up to $2,000 \mathrm{MW}$ on Turkish territory, but very close to the border triangle with Iraq and Syria. The primary purpose is to import KRG gas into Turkey and pay for some of the gas with electricity generated there (See Map 1).

\footnotetext{
${ }^{28}$ Turkey issues first license to import northern Iraq gas, September 142013 , http://english.alarabiya.net/en/business/energy/2013/09/14/Turkey-issues-first-license-to-import-northern-Iraq-gas-.htm/
}

February 2014: Natural Gas in the Turkish Domestic Energy Market: Policies and Challenges 


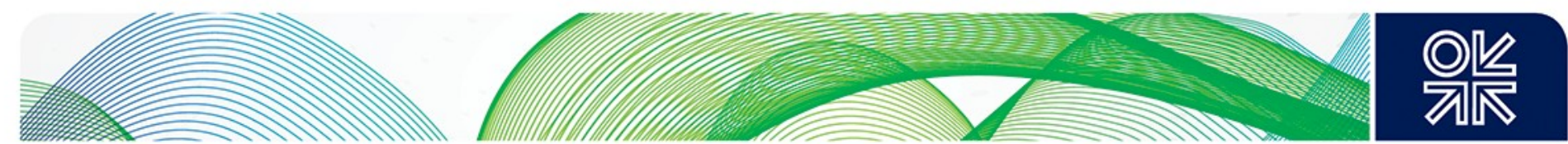

Map 1: Iraq oil and gas

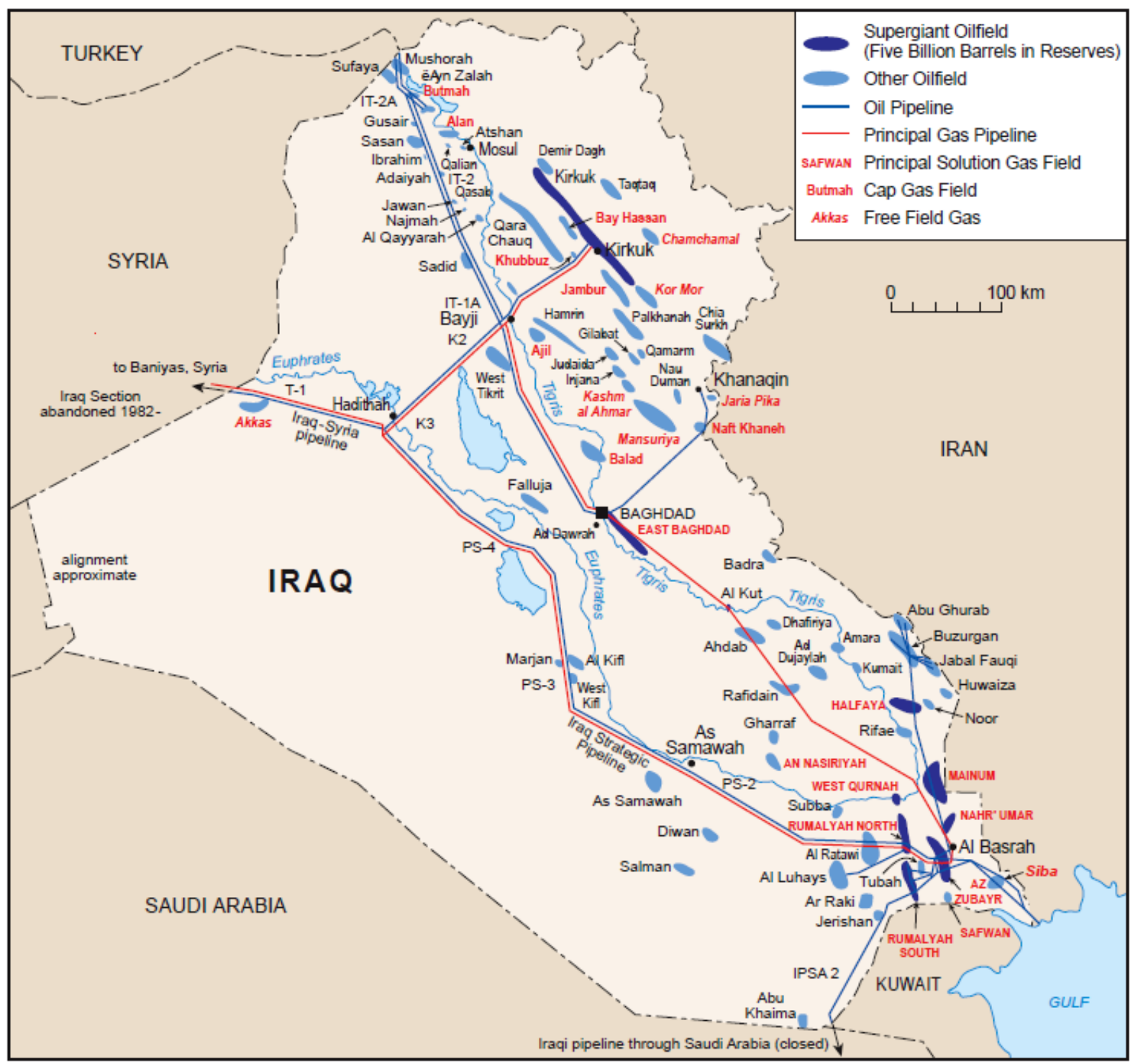

Kurdistan Region natural gas export plans (as currently understood) are as follows:

- KRG gas exports to Turkey from Miran by 2015-2016;

- Genel to produce $4 \mathrm{bcm} / \mathrm{y}$ for export by 2014-2015, and an additional $4 \mathrm{Bcm} / \mathrm{y}$ by 2017;

- A gas pipeline to the Dohuk power station in Kurdistan was completed in March 2013. This will later extend to a new power plant that is planned to be built in Turkey and part of the power generated there will return back to Iraq for the KRG and for neighbouring provinces. The existing gas pipeline will be connected to Dohuk's power plant;

- EMRA gas import license not yet awarded due to lack of GSA;

- Central processing facility planned for associated gas with tie-ins to the Khor Mor-Erbil-Dohuk export pipeline. 

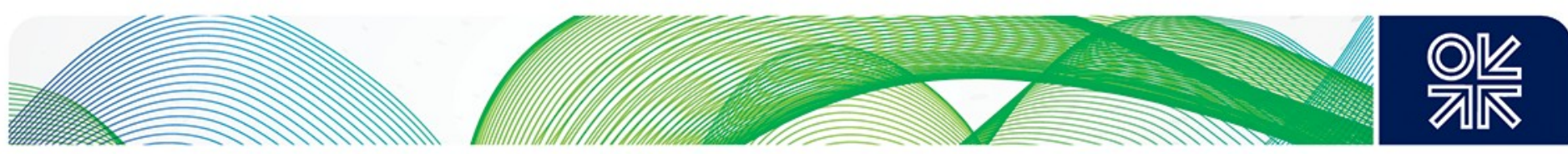

Turkey is hoping to import more LNG after 2015 (before SD2 gas becomes available), and plans to reduce the imports of expensive gas from Russia and Iran (a supplier with an unreliable track record). Political problems arising from US and EU sanctions mean that it plans to replace Iran gas gradually with pipeline gas from Iraq. If the political difficulties of the Ankara-Erbil-Baghdad triangle can be solved, the KRG is aiming to launch natural gas exports to Turkey as soon as 2015-16. According to the KRG Oil Minister, the region could supply natural gas to Turkey at an attractive price for Turkey \$4-5/MMbtu. However it could be problematic for Ankara to solve the political tensions in Iraq and start importing the gas from 2015. Therefore it is more likely that gas exports to Turkey could start no sooner than 2020, in the light of political constraints and the absence of national law on exploration and energy transport in Iraq that prevent Turkey reaching agreement with either government to sign contracts.

\subsection{Domestic production}

In order to reduce dependence on natural gas imports, exploration and investment in new indigenous gas sources continue. However it is worth mentioning that even in the best case, Turkey's domestic production will not make up a substantial part of its gas balance.

The main exploration activity is in the Akcakoca, Ayazli-1 wells in the Western Black sea. Akcakoca is the biggest natural gas field in Turkey and has a natural gas production rate of 360 thousand $\mathrm{m}^{3} / \mathrm{d}$. TPAO and Shell signed a joint operation agreement on November 23, 2011 to start exploration and production activities in offshore areas of the Mediterranean region of Antalya. These activities began at the end of 2013 and drilling will be completed in $2016 .^{29}$

In addition 13 companies along with TPAO have started exploration in Turkey. Proved natural gas reserves are estimated at $26 \mathrm{Bcm}$, and recoverable gas at $20 \mathrm{Bcm}$, but this will only ever be sufficient to cover a very small proportion of Turkey's consumption.

Table 11: Total Proved, Recoverable, Cumulative and Remaining Recoverable Gas

Source: EMRA

\begin{tabular}{|l|l|l|l|l|}
\hline & $\begin{array}{l}\text { Original Gas } \\
\text { in Place }\end{array}$ & $\begin{array}{l}\text { Recoverable } \\
\text { Gas }\end{array}$ & $\begin{array}{l}\text { Cumulative } \\
\text { Production }\end{array}$ & $\begin{array}{l}\text { Remaining } \\
\text { Recoverable } \\
\text { Gas }\end{array}$ \\
\hline & $\mathrm{bcm}$ & $\mathrm{bcm}$ & $\mathrm{bcm}$ & $\mathrm{Bcm}$ \\
\hline Total & 0,26 & 0,21 & 0,13 & 0,7 \\
\hline
\end{tabular}

\footnotetext{
${ }^{29}$ Deloitte (2012),
} 

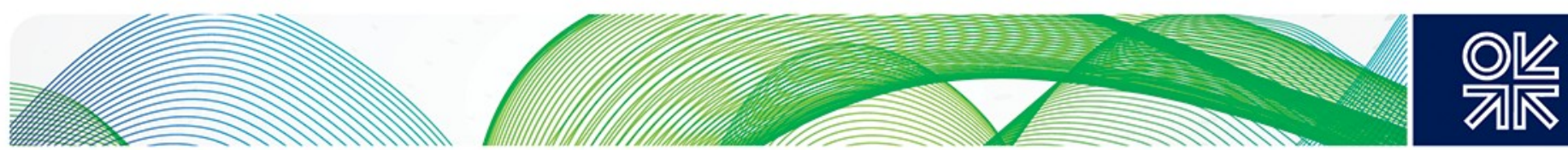

Map 2: Natural Gas Reserves in Turkey

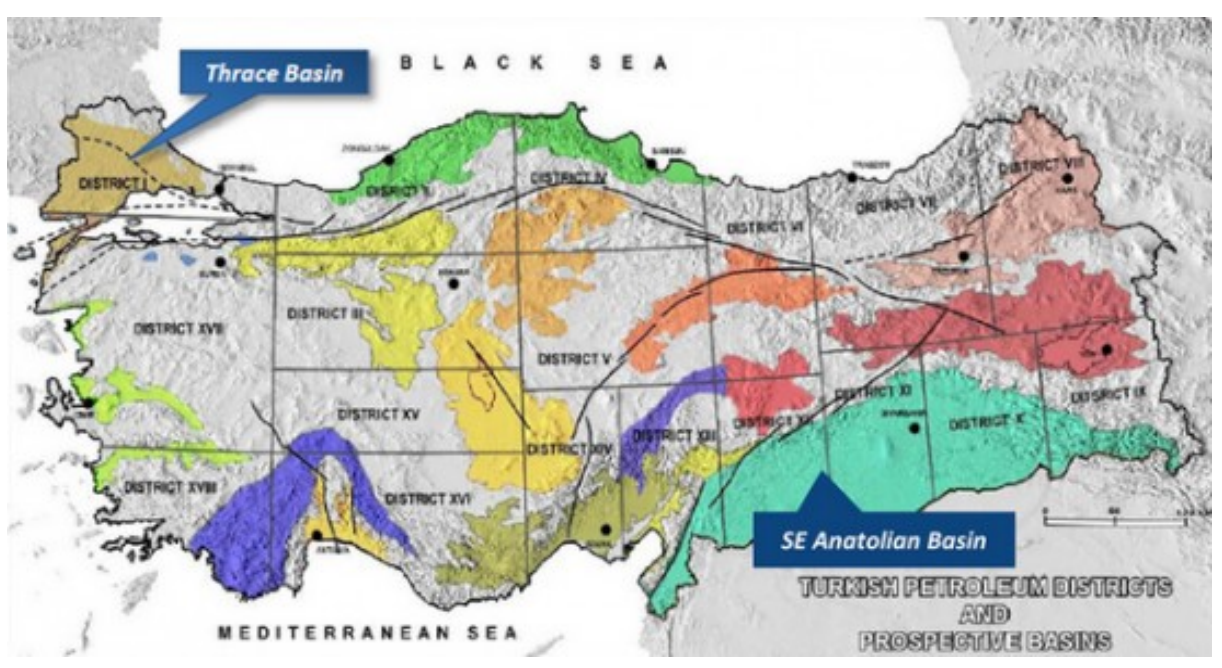

Source: Natural Gas Europe

In 2012 , domestic gas production was $812.5 \mathrm{MMcm}$ (64\% private companies and $36 \%$ TPAO), $1.5 \%$ of the total consumption.

\section{Figure 17: Natural Gas Production in Turkey}

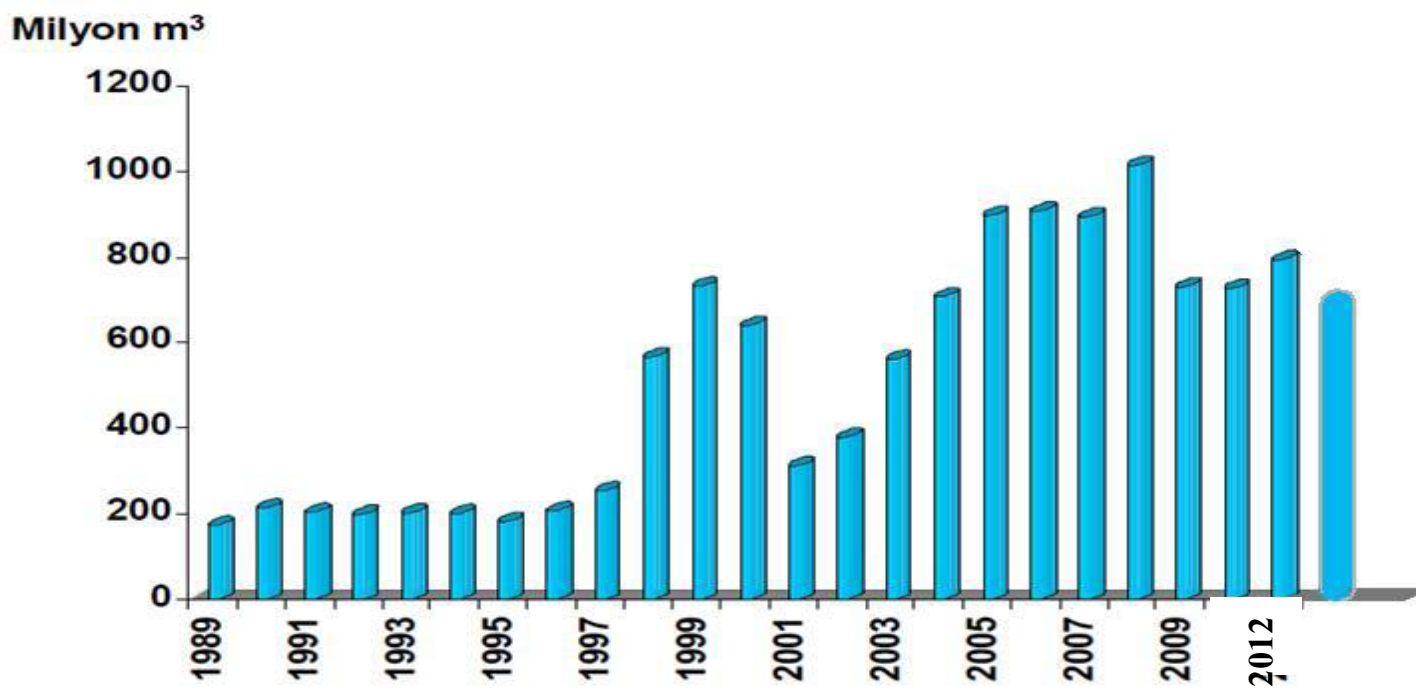

Source: PIGM

During the last 10 years, the total number of wells drilled in Turkey was 1,122, of which 318 yielded oil, 306 were gas wells, and 471 were dry. Evaluation work continues on 27 wells. 

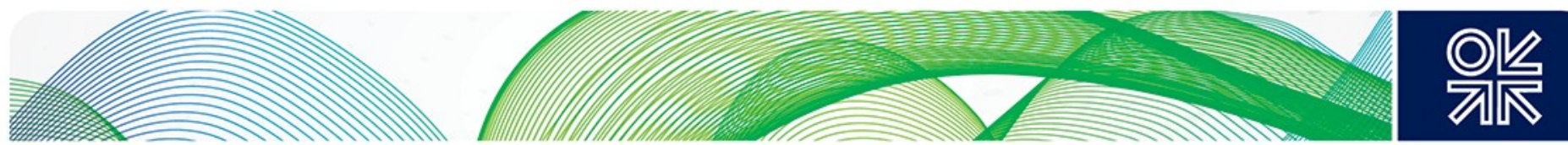

Figure 18: Total Number of Licenses 2012

Figure 14: Total number of licenses 2012

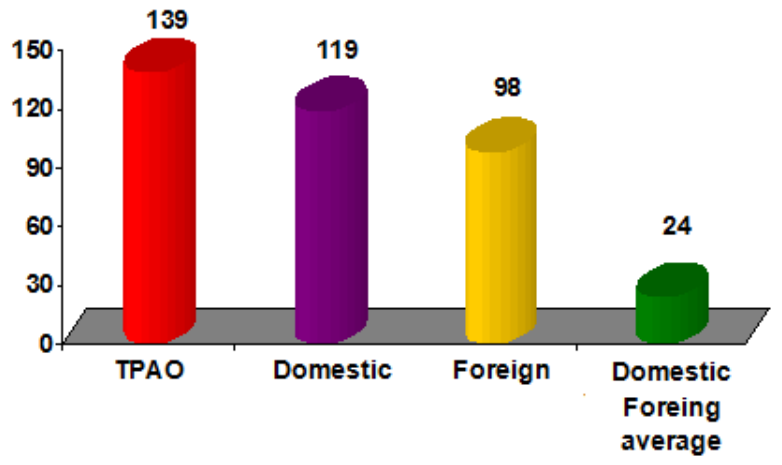

Source: EMRA

Figure 19: Natural Gas Production 2012

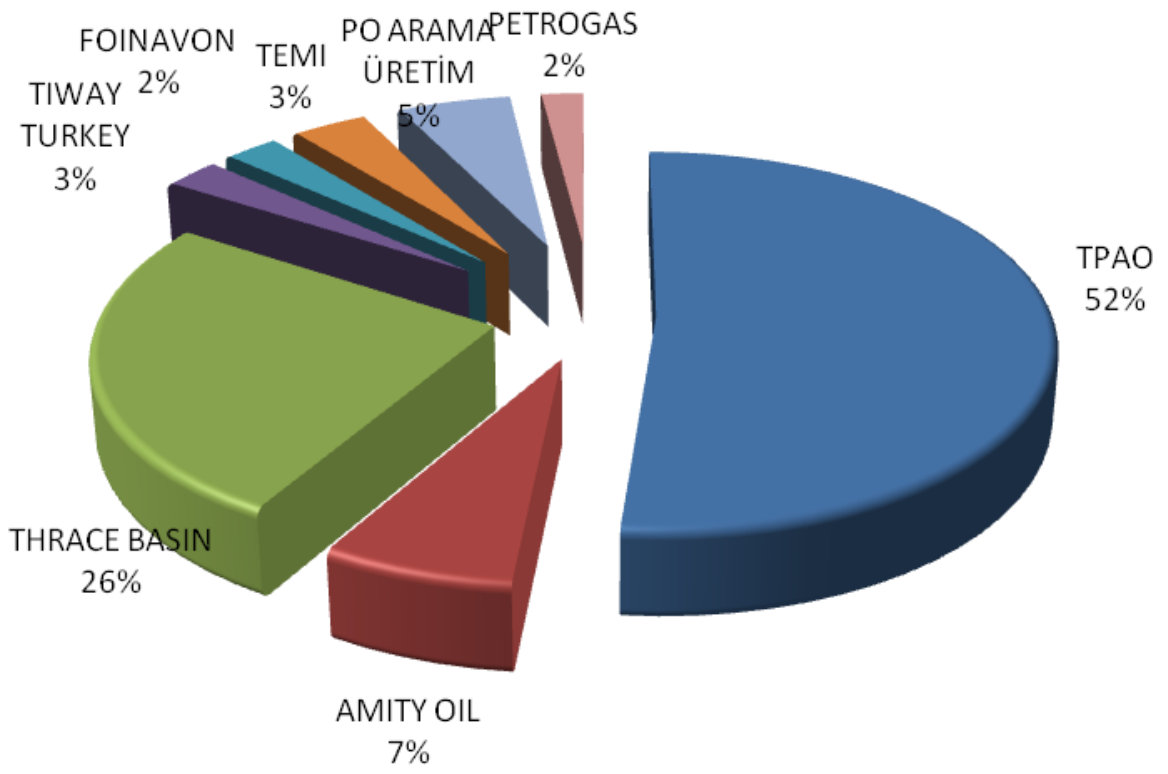

Source: EMRA

The General Directorate of Petroleum Affairs (GDPA) of the Republic of Turkey has been awarding new exploration licenses to foreign and local companies to conduct feasibility studies of both conventional and unconventional (shale gas) fields. To date 380 licenses have been granted to local and foreign companies for a total area covering 366 thousand $\mathrm{m}^{2}$. Turkish Petroleum Corporation (TPAO) is the main public company in upstream projects in Turkey and it is conducting joint operations with Shell and Exxon Mobil to explore for shale gas in the Mediterranean, Black Sea and Diyarbakır.

Natural gas producer companies sell domestically produced gas to wholesale companies, importer companies and distribution companies with wholesale licenses, who are free to sell to consumers the natural gas produced for internal consumption and use. In 2012: 

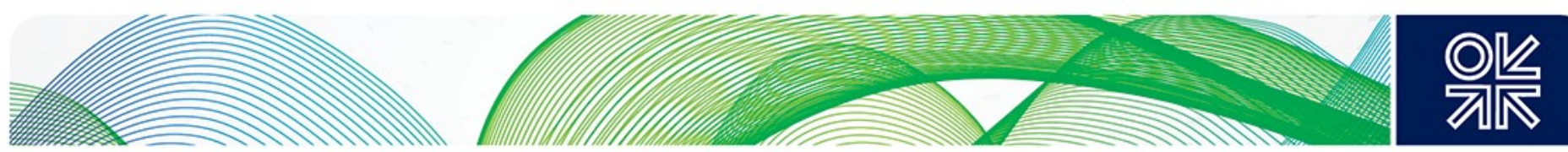

1. $37 \%$ of extracted natural gas was sold to wholesale companies,

2. $42 \%$ was sold to industrial companies,

3. $14 \%$ was sold for power generation, and

4. $7 \%$ was sold to distribution companies in Turkey.

Apart from conventional natural gas, upon the initiative of the Turkish Energy Ministry, shale gas exploration and production activities were launched in the Southern Anatolia region in 2012. It is estimated that there could be shale gas potenial in the Hamitabat and Mezdere districts of the Thrace basin. ${ }^{30}$

According to data that EMRA has obtained from oil and natural gas wells drilled to date in Southeastern Anatolia and Thrace in Turkey, the indicative estimate of shale gas resources is 420 $\mathrm{Bcm}$, whereas shale oil resources are estimated at 500 billion barrels. To compare with other European country estimates, Poland has $5.3 \mathrm{Tcm}$ of gas resources, France $-5.1 \mathrm{Tcm}$, Sweden -1.2 $\mathrm{Tcm}$, Denmark $-0.7 \mathrm{Tcm}$, Ukraine $-0.6 \mathrm{Tcm}$ and the Netherlands $-0.5 \mathrm{Tcm}$.

Drilling on Turkey's first shale gas well, Sarıbuğday-1, started in August 2013. TPAO has been granted two licenses for shale gas exploration in Diyarbakir following a study carried out in partnership with Shell. Wells are scheduled to be drilled until the end of 2014.

In Thrace private companies such as Thrace Basin and Amity Oil are already extracting natural gas and selling to the market. The companies have successfully applied hydraulic fracking drilling methods to extract shale gas from conventional wells, ${ }^{31}$ a procedure which could be applied in other parts of Turkey.

\section{Map 3: Shale Gas Potential Areas in Turkey}

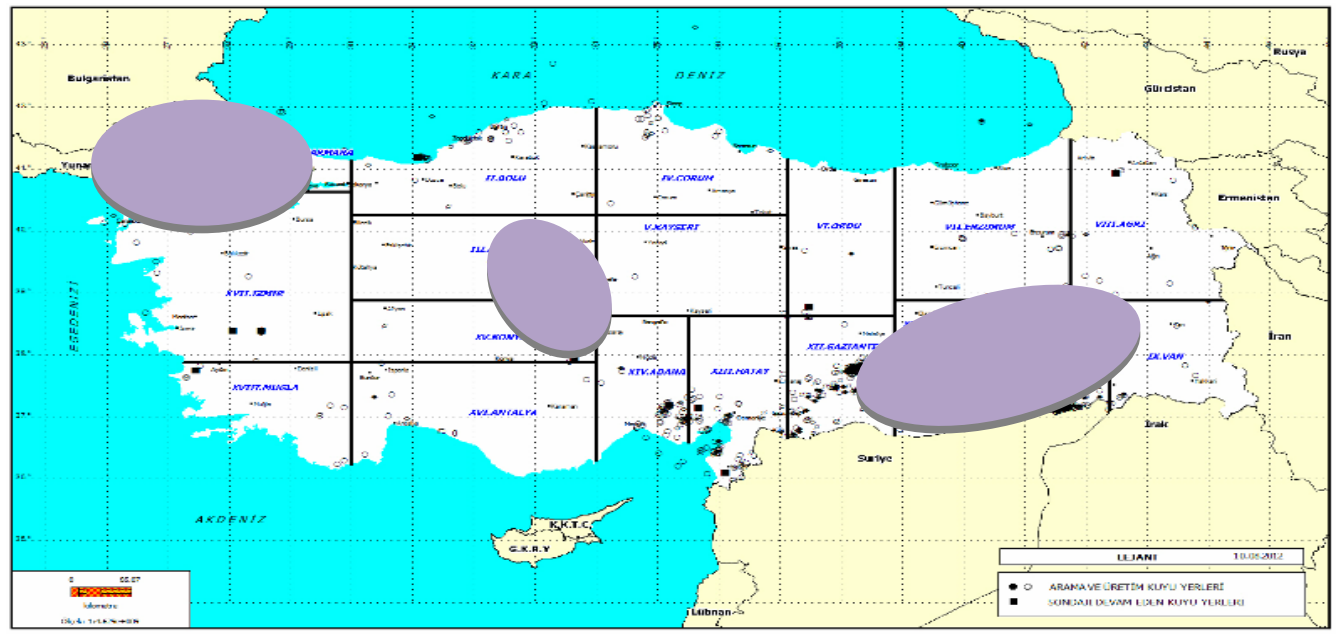

Source: EMRA

The Nigde-Konya and Ankara regions are also expected to have shale gas and shale oil resource potential. According to GDPA, the investors are conducting feasibility studies in these regions based on the data obtained in previous studies. If the results are positive exploration and production are expected to start soon.

\footnotetext{
${ }^{30}$ EIA World Shale gas resources: An Initial Assessment of 14 regions Outside the United States.

${ }^{31}$ Official web page of TPAO, http://www.tpao.gov.tr/eng/?tp=m\&id=78;
}

February 2014: Natural Gas in the Turkish Domestic Energy Market: Policies and Challenges 

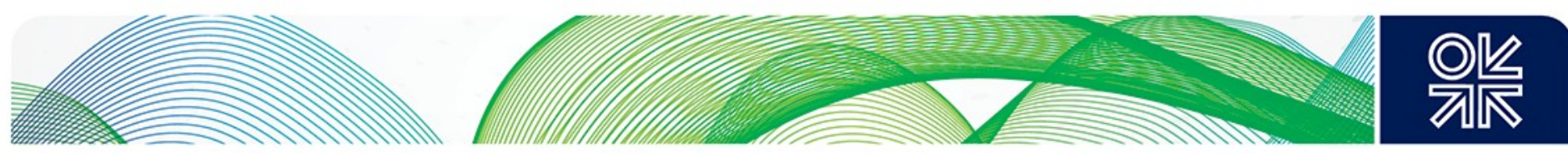

An advantage for shale gas exploration in Turkey is that there are fewer environmental and legal constraints compared with other European countries. The Ministry of Environment and Urban Planning announced a by-law, published in the Official Gazette in April 2013, that exempted major shale gas extraction projects from Environmental Impact Assessment. The potential negative impacts of the shale gas extraction are well known, the worst being water pollution. Nevertheless the government of Turkey is providing very favorable legal and commercial conditions for private companies to invest in shale gas exploration in Turkey. This policy, and Turkey's well-positioned location to supply gas to the international markets, has already attracted many US, UK, Canadian and other foreign companies to start conducting feasibility studies. Royal Dutch Shell and US company Trans-Atlantic Petroleum Ltd. are among the leading companies that have already commenced shale gas exploration projects in eastern and western Turkey.

It is possible that Turkey will yet face opposition from social and environmental groups, urging the government to start applying legal and environmental constraints to shale gas extraction once the real work starts.

The main question that arises is whether it is more commercially viable to develop domestic production of shale gas or to import gas. The industry is in its infancy in Turkey and there is little accurate data on the reserves potential. Shale gas development costs are likely at least initially to be higher than those in the US where a mature and competitive drilling and service industry exists. Ultimately the well flow rates tested by drilling exploration wells relative to the cost base will determine shale gas viability in Turkey.

It would be naïve to hope that shale gas in Turkey will come on stream any time soon. It will probably take at least a decade before Turkey will see unconventional gas production in significant quantities. Even then it is highly unlikely to reach levels equating to self-sufficiency.

Consequently, with strong natural gas demand growth and negligible domestic gas production Turkey's dependence on foreign suppliers will continue for the forseeable future.

Turkey should therefore focus on importing cheaper gas from Iraq and creating a politically and commercially favourable environment for importing and transiting gas from Israel, Lebanon and Cyprus and deep water discoveries in the Mediterranean. 

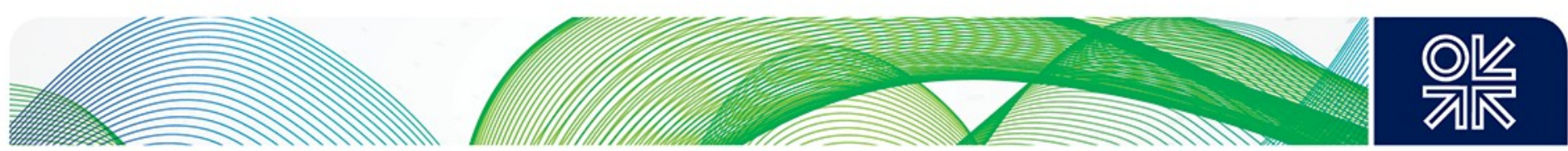

\section{Development of Regulatory Framework: What Kind of Liberalization of the Domestic Natural Gas Market for Turkey?}

As has been already discussed in this study, the Turkish government's strategic objective is to achieve 4 main goals by the liberalization of the market:

1. to create a competitive market;

2. to ensure security of supply;

3. to minimize and gradually nullify the state budget deficit and BOTAŞ's losses, shifting the risks and investment obligations to private companies; and

4. to turn Turkey into a natural gas trading hub, playing the role of a bridge for hydrocarbon flows from the East towards the West in a fully liberalized environment.

However, different approaches have been taken towards liberalization policy. Some advocate full liberalization and full unbundling of market activities (the government), while others, mainly some representatives of opposition parties, argue that liberalization in the energy sector is against the country's national interests and that government control of this strategic sector of the economy must continue. Also, the vertically integrated natural gas 'incumbent' companies continue to have the role of 'national champions'.

There is no doubt that liberalization of the market and linked unbundling of the 'national champion' BOTAŞ will facilitate cost transparency, and fair and healthy competition in the import, wholesale and distribution sectors. This process of importing natural gas at a more competitive price than BOTAŞ, but also competing in selling this gas in the domestic market for a lower price, requires significant investment throughout the gas value chain, including building LNG and underground gas storage facilities.

Given Turkey's increasing diversity in natural gas supply and its maturing natural gas market, the participation of private companies in the import, wholesale and distribution of natural gas can only further improve the domestic market structure.

With these strategic objectives in mind, the EMRA first presented the Natural Gas Market Law (NGML) No. 4646 in $2001 .^{32}$ This was a fundamental step on the way to establishing a liberalized natural gas market in Turkey. In the last 12 years the transition to an open market has, however, been too slow. The first release of supply contracts only occurred between the end of 2007 and Q1 2009 with an annual total volume of $4 \mathrm{Bcm}$, and in 2011 with annual volume of $6 \mathrm{Bcm}$. A comprehensive revision of the Law was carried out in May 2013 and the new draft with amendments to the NGML has been prepared. This is expected to be approved by Parliament in 2014. The legal unbundling of BOTAŞ, which is covered by the main Law has not yet been realised.

The main Law for the liberalisation of the market, NGML 4646 was approved on April 18, $2001 .^{33}$ The purpose of this Law is to bring to the Turkish natural gas market high quality and inexpensive gas in a continuous and an environmentally responsible manner. It was expected that this would happen within the framework of a competitive, financially strong, stable and transparent natural gas market, and ensure the establishment of independent natural gas market regulation and supervision.

\footnotetext{
${ }^{32}$ NGML 4646, Adoption Date:, 18.04.2001. Available in Turkish at: http://www.epdk.gov.tr/index.php/dogalgazpiyasasi/mevzuat?id=50

NGML 4646, http://www.epdk.gov.tr/index.php/dogalgaz-piyasasi/mevzuat?id=50
}

February 2014: Natural Gas in the Turkish Domestic Energy Market: Policies and Challenges 

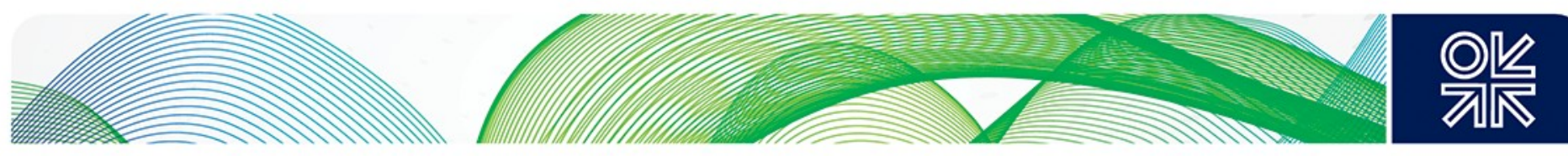

The Law regulates the main activities of private and public sector of the market which can be summarised as follows:

- Import: Contract or uncontracted volume transfer;

- Domestic natural gas production;

- A liquid, liberalised, wholesale market;

- Transmission: open-access, but de facto monopoly of BOTAŞ;

- LNG and Storage, in principle open to third parties;

- Distribution: Private Sector "Contracting out" and privatization;

- A competitive retail sector, and

- Construction services: Subject to Certificate.

Another important issue of full liberalisation of the natural gas market is ownership and unbundling splitting BOTAŞ's activities into different legal entities, each with its own accounts. These import, wholesale, transport, storage and distribution activities will be split into different legal entities. According to the NGML and the new draft Amendments, BOTAŞ is to be split into 3 legal entities by 2015: transportation, LNG and storage operations, and importation. In the Transitional Provision Article 2 of the NGML, the split of BOTAŞ was scheduled for 2009, but in the new draft is now targetted for 2015.

\subsection{Summary of the 2013 Draft Amendments to the NGML}

A revised version of the NGML 4646 and draft amendments were presented to the Council of Ministers and the Parliament on May 30, 2013 and was expected to come into the force by the end of 2013, but is the subject to changes and modifications before approval. This draft represents an important development and reflects major changes to the original NGML, including the unbundling of BOTAŞ and decreasing its market share by up to $50 \%$ -

The main changes in the NGML reflected in the draft version of the revision can be summarised as following:

1. Turkey being considered as a market in which gas can be traded. Later this could happen on the Energy Exchange floor, which is envisaged to be set up as reflected in Article 11 of the Electricity Market.

2. In the original version, the NGML provides that the market share of BOTAŞ would be reduced to $20 \%$ by 2009 . The revision of the Law states that the BOTAŞ share should be reduced to $\mathbf{5 0 \%}$. However it does not state any timeframe for this process and it makes uncertain whether this process will be completed. This constitutes a risk for the activities of the private sector and for future investments.

3. In order to ensure competition in the wholesale market, a wholesale company cannot sell more than $\mathbf{2 0} \%$ of Turkey's annual natural gas consumption. This means that if in 2012 Turkey's gas demand was $47 \mathrm{Bcm} / \mathrm{y}$, one company could sell only $9.4 \mathrm{Bcm} / \mathrm{y}$.

4. According to the draft revision (while there is no provision covering the accounting split of distribution and retail in the NGML), a distribution company can also have a retail licence obtained from the EMRA. There should be separate bank accounts for distribution and retail businesses; ideally, they should be different companies. The targeted timeframe for fulfilling this provision is 2015 .

5. The provision regarding the storage of $10 \%$ of natural gas remains unchanged. Import license holding companies have to store $10 \%$ of their annual gas imports. 

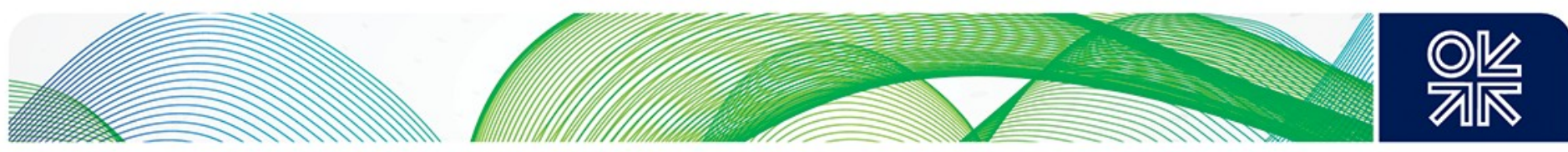

6. According to the draft, the distribution companies have been buying gas from private companies and BOTAŞ. However, the draft provides that the distribution companies have to announce a tender and buy natural gas from the tender winner company. This is to ensure fair competition among the wholesale companies and importers and to prevent purchases of gas from the distributor's own wholesale company. This may be seen as a gap in the Law since the private companies cannot compete with BOTAŞ in the tender and BOTAŞ will again have the majority share in the market.

7. The draft provides that in order to subsidize the gas price in the household sector, the law gives authority to the Council of Ministers to take decisions on price approval. The subsidisation of the household sector is the main reason why private companies cannot sell gas to this sector, and the main reason why they sell gas mainly to the power generation sector. This means that the subsidisation of the residential sector of the country will continue for an indefinite period.

8. A new provision was added with regard to gas imports, which was not included in the original version of the NGML. From the supply security perspective the MENR will be granted the authority to sign new contracts or renew expired agreements via BOTAŞ, meaning that BOTAŞ, if the MENR decides so, can keep its current import share in the market (for instance SD2 agreements signed in 2011).

9. The draft provides that new transportation companies should be established. This provision will weaken BOTAŞ's position in the market, especially from the financial point of view as transportation along with storage is its most lucrative business. As an example, newly established transportation companies can transport natural gas from the TANAP to the market within the country as well as gas coming from Iraq, Israel, Egypt and other countries either via the TANAP or dedicated pipelines.

10. Another important provision of the Draft on the ownership unbundling of BOTAŞ provides that by 2015 BOTAŞ will be split into 3 legal entities - Transportation Company, LNG and storage facility operator, and natural gas importer. BOTAŞ losses as a result of the subsidisation of the residential sector will then be visible as will compensating income from transportation and storage.

Thus, the government will not be directly represented in every segment of the natural gas market, but it has to put regulation in placed to reflect the country's objectives and interests in international energy geopolitics.

For a country with negligible natural gas resources, it is very important to control the market by setting a price strategy. The natural gas price for residential customers is set by the government, and this gives the government a crucial lever for steering the market without having a strong direct presence. The government has leverage on the industry and especially power generation sectors by its subsidy activities.

The 2013 draft amendment to the NGML is expected to be approved by the Parliament in 2014 but with some modifications. There are still some gaps in the Draft such as the absence of a definite timeframe for reducing the BOTAŞ market share to $50 \%$; and the provision stating that distribution companies should buy gas from tender winners, which further strengthens the BOTAŞ position in the market. These gaps should be modified and amended before the Parliament approves its final version.

\subsection{Wholesale}

The development of the liberalisation of the wholesale market started in 2007, after which private natural gas importing companies and spot LNG importers entered the market, and domestically produced natural gas was sold through periodic tenders. After the revision made to the Network Operation Principles (NOP) provisions in 2008, title transfers and natural gas exchange in a virtual 

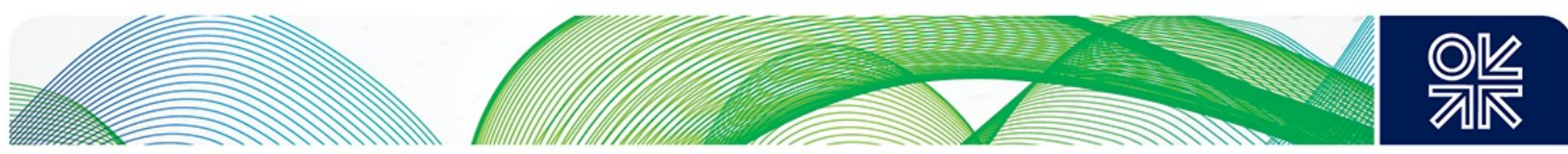

environment ${ }^{34}$ was made possible. This in its turn partly broke the monopoly of BOTAŞ over wholesale market activities.

The Turkish domestic natural gas market is quite complex, with players consisting of a group of suppliers, wholesalers, network operators and distributors and consumers (eligible and non-eligible). All the activities of the market players and between the players are regulated by the NGML 4646 and its amendments.

The market mechanism can be explained as follows: suppliers, either importers (BOTAŞ and private companies, pipeline gas and LNG) or domestic producers (both TPAO and private companies) supply gas to wholesalers. The wholesalers sell the gas to distributors via the BOTAŞ transportation system, paying fees for transportation and use of the system. Finally distributors sell the gas to the consumers. At the same time importers and domestic producers may sell gas directly to distributors, thereby bypassing the wholesalers. In this case, according to the Law to ensure fair competition, the distributor company cannot be a legal entity of the importer but should be a company with different legal ownership. It is worth mentioning that all importers into Turkey hold wholesale licenses. However, domestic suppliers cannot sell natural gas to distributors directly without having a wholesale license. All market players are allowed to import LNG, if they hold an import license from the EMRA. However, according to the Law, BOTAŞ cannot renew its existing LNG or pipeline gas contracts.

Also, volume release is contained within the liberalisation policy, meaning that BOTAŞ transfers certain imported volumes of natural gas to private companies, who can sell in turn to distributors. This is another method of creating competition in the wholesale market. The amendments made to Law No. 5367 provide that BOTAŞ shall hold volume release auctions if the contract release method fails, as a result of failure to sign a contract with the seller. ${ }^{35}$ This may happen if any of the five gas exporters from which Turkey imports natural gas refuses to sell the gas to a company other than BOTAŞ. However, until now no volume transfers have been necessary.

When and if volume transfers are realised by BOTAŞ, the conditions of the original contracts do not change. This may limit operational flexibility compared with contract releases, where private companies purchase the gas directly from foreign suppliers and can negotiate contract changes.

There are requirements for natural gas distribution companies stated in the NGML as follows:

- to purchase a maximum $50 \%$ of their purchase quantity from the same supplier;

- to certify that they purchase natural gas from the most economical source, and

- to post their sales prices (the obligation for wholesale companies) applied to distribution companies and eligible consumers on their web site. ${ }^{36}$

If supply quantities exceed demand, for instance, in the seasonal low demand period, it is inevitable that this will lead to price discounts in the market. This factor creates a buoyant environment for wholesale companies that do not import gas but who may buy from importers and sell to distribution companies.

There is a difference between the price charged by BOTAŞ and by other importing companies to distribution companies and eligible consumers, creating room for trade both in the market and at virtual points. Since the distribution companies and eligible consumers prefer to buy gas from an importer other than BOTAŞ, the traded volume of the gas at the virtual point is increasing from year to year, from $1.9 \mathrm{Bcm}$ in 2009, to $7.8 \mathrm{Bcm}$ in 2010, and $8 \mathrm{Bcm}$ in 2011.

\footnotetext{
${ }^{34}$ Deloitte (2012) (p. 40),

${ }^{35}$ Deloitte (2012) (p. 41)

${ }^{36}$ Deloitte (2012) (p. 41),
}

February 2014: Natural Gas in the Turkish Domestic Energy Market: Policies and Challenges 

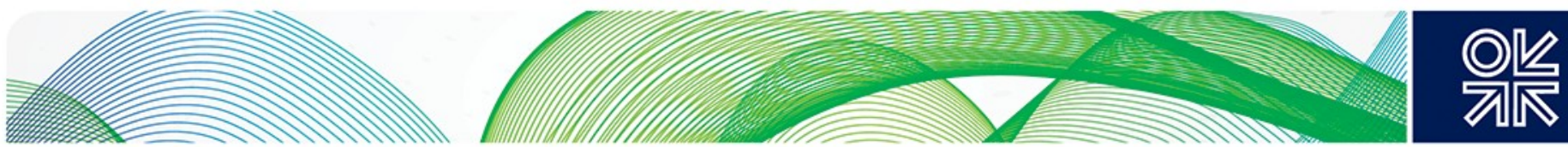

Since 2007, when the BOTAŞ monopoly ended with contract releases, a very efficient process was launched, and experience and knowledge has been gained by the private sector. This process will continue and can contribute to development of a natural gas trade mechanism in the market further enabling the liberalisation of the market.

\subsection{Transmission Infrastructure}

According to the NGML, private companies are allowed to invest in and build their own transport pipelines. The Law also provides for the establishment of new transport companies. However, up to now not a single company has applied for a license to build a pipeline. The reason given is that it is not cost-effective for the investing company to build a pipeline and transport gas but to leave capacity in the pipeline for third parties, which is not guaranteed to be sold.

BOTAŞ has expanded its transport system to cover the whole country. It is almost completed and the current total length of the system is $13,000 \mathrm{~km}$. BOTAŞ is planning to invest in loop lines and new high pressure compressor stations to enable all contracted volumes to be carried, especially from its Eastern suppliers. The company has already invested in the Hanak compressor station close to the Turkgözu entry point, where natural gas from Azerbaijan enters Turkey. It has also invested in the construction of the Erzincan high pressure compressor station, which is located on the pipeline from Azerbaijan and Iran. This will increase the import capacity of natural gas from Azerbaijan from the current $6 \mathrm{Bcm} / \mathrm{y}$ up to $10 \mathrm{Bcm} / \mathrm{y}$.

\section{Map 4: BOTAŞ Natural Gas Transmission System}

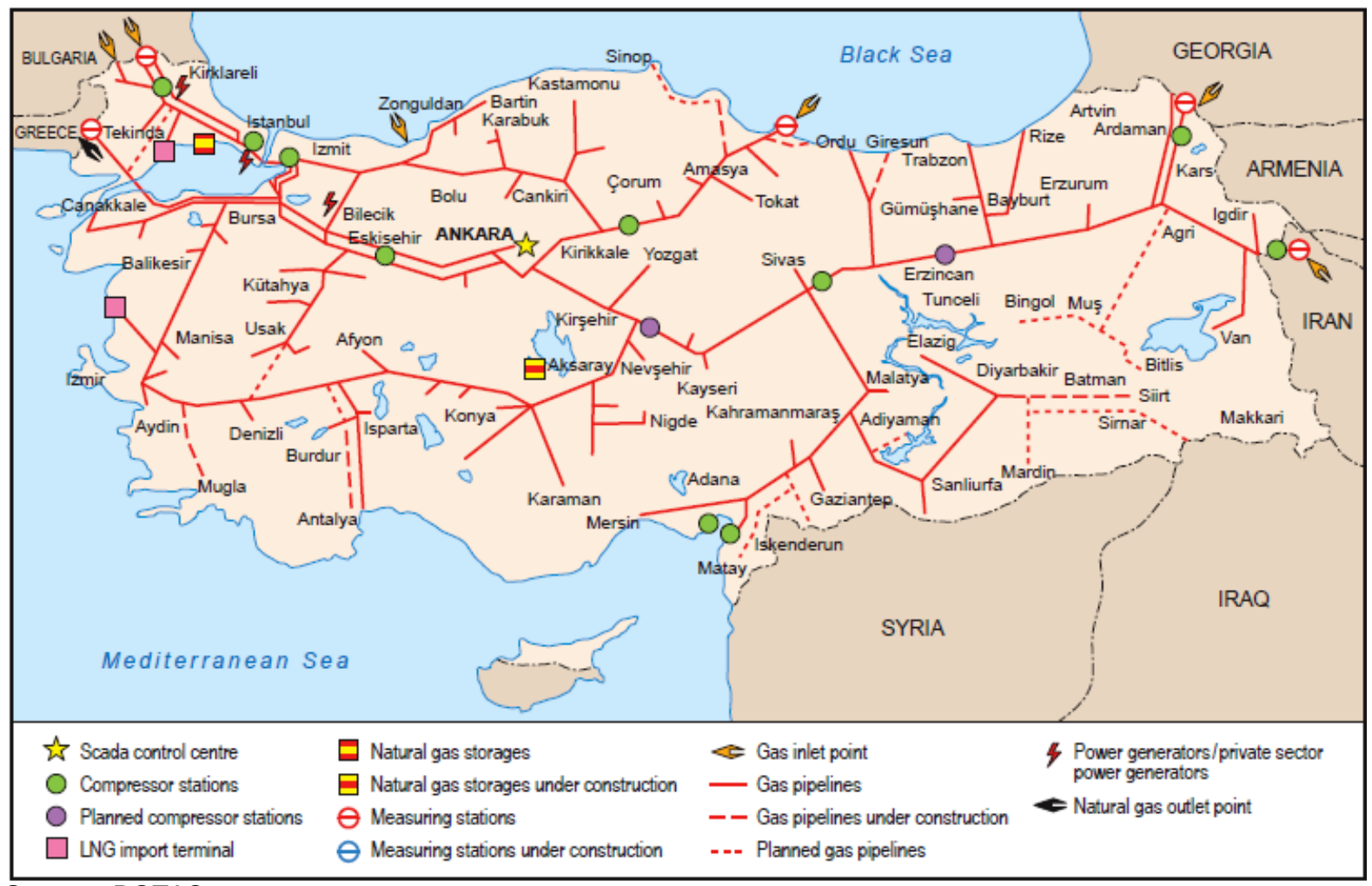

Source: BOTAŞ 

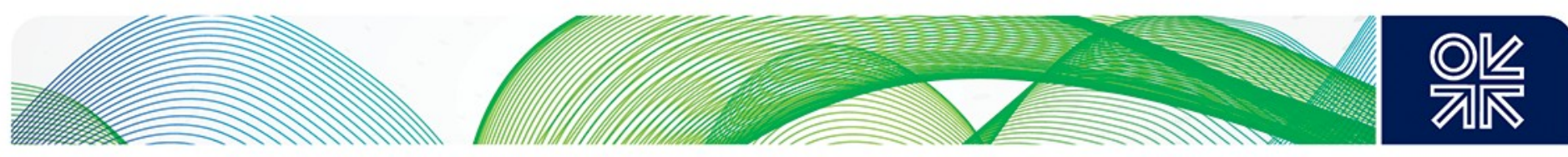

Natural gas enters the main BOTAŞ transport system at the following points;

1. From Azerbaijan through Turkgözu

2. From Iran through Gürbulakentry

3. From Russia through Malkoçlar (Balkan) and through Durusu (Blue Stream)

4. Through LNG terminals at Marmara Ereglisi and Egegas Aliağa

5. From the TPAO underground store at Marmara Degirmanköy

6. From two production sites in Turkey (TPAO Akcakoca Cayağzı Production and TEMI Edirne Production).

Natural gas is taken off the system at around 270 pressure reduction and metering stations, which are directly connected to the system.

The Law and the draft amendment to the Law provide that the unbundling of BOTAŞ will take the form of ownership unbundling. This means that the ownership and operatorship responsibilities of the transport system will be split and shifted to a fully independent operator. The transport system tariff and operator will be subject to regulation. According to the draft amendments the latest date for this process to be complete is 2015 .

Basic principles applicable to network access and detailed obligations of transportation licensee are provided in the Transmission Network Operation Regulation, issued by the EMRA on October 26, 2002. BOTAŞ started preparing 'Third Party Access to the Transport System' in 2003 under the name approved by the Council of Ministers as 'BOTAŞ Transmission Network Operation Principles' shortly referred to as 'NOP'. At the same time BOTAŞ started preparing the 'Transportation and Dispatch Control Tariff' to be submitted to the Council of Ministers for approval in line with the provisions of the NOP. ${ }^{37}$

The Network Code consists of two parts, Basic Practices and Operational Provisions. The Basic Practices part covers carriers' and transporters' obligations, application conditions for system entry by capacity reservation or making a connection as well as system entry disputes. The second part consists of capacity reservation, dispatch control and system balancing, carriage quantity statement and programming, entry and exit conditions, gas for domestic consumption, passage of possession and liability, allocation, gauging, quality and pressure, emergency, day of system stress and limitedcapacity day, maintenance, force majeure, invoicing and payment, change procedure and other sections. Under article 16.1 of the Network Code, any disputes arising between the shipper and the transporter in respect of the issues of capacity reservations, cancellations, allocations, system balancing participation fees, interruption balancing fees, service interruption fees, emergency, tough day and limited-capacity day practices are to be resolved by the EMRA. ${ }^{38}$

The monopoly position of BOTAŞ was broken only in 2007 by the private wholesale company AksaDogalGazTopdanSatiş, A.S. when it signed a Standard Transportation Contract and gained access to the system as the first private shipper to ship gas produced by TPAO at the Akcakoca site. There are now 27 shipper companies in the Turkish domestic market with system access.

The process of capacity reservation for the BOTAŞ transport system takes place every year from September until the end of December. From September 1 to September 15, BOTAŞ publishes maximum allocatable capacity for Entry/Exit points in the Electronic Bulletin Board (EBB) through which the nomination process with shippers is executed. By September 30, BOTAŞ receives capacity reservation requests from private companies willing to ship gas on the system. By September 30,

${ }^{37}$ Deloitte (2012) (p. 25),

${ }^{38}$ EMRA Natural Gas Market Report 2012, available in Turkish at:

http://www.epdk.gov.tr/documents/dogalgaz/rapor yayin/Ddp yayin rapor 2012.pdf

February 2014: Natural Gas in the Turkish Domestic Energy Market: Policies and Challenges 

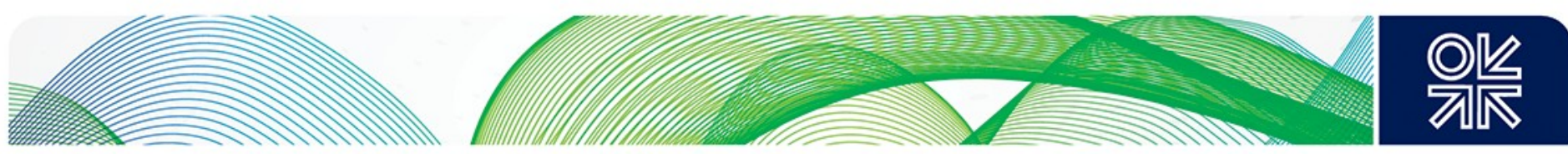

BOTAŞ prepares the Transportation and Dispatch Control Tariff Proposal to the Board. By December 1, BOTAŞ publishes the Capacity Reservation and Usable Capacities on the EBB. An Entry/Exit System is applied for capacity reservation and for the duration of reservations, with a maximum of one year and a minimum of one month.

There are seven importers and 27 shippers of natural gas in Turkey. Other shippers that do not have access to the system can trade gas on the virtual hub by buying gas from either importers or wholesalers. The Turkish hub, comparable to the UK National Balancing Point (NBP), is UlusalDengelemeNoktası (UDN), where shippers can trade virtually. On the UDN, shippers can trade day ahead within the commercial conditions they agree among themselves. The prices are not published. In order to trade in Turkey, a company needs to be a wholesale license holder and apply to Transmission System Operator (TSO) before or within the gas year. Companies can trade with other shippers or can physically deliver gas to end users (Figures 20, 21). Title transfers between shippers are carried out at virtual 'Transfer Entry/Exit Points' defined at each Entry Point. The virtual 'National Balancing Point', which is defined as the whole system, is used for day ahead gas exchanges between shippers to minimize post-day imbalances. ${ }^{39}$ The difference between Transfer Points (TP) in the Turkish Network System and the NBP can be summarised as following:

TP:

- Directly connected to a physical entry point

- At least one party should be a first-hand shipper such as importers, producers and similar

- Needs reserved capacity, and

- Allocations differ from allocations at an entry point (by using pro rata allocation)

NBP:

- Not connected to a physical entry point

- It can be made between any shipper

- Does not need reserved capacity

- Allocations are equal to notifications

Figure 20: Virtual Trade by the Private Sector $(\mathrm{Bcm})$

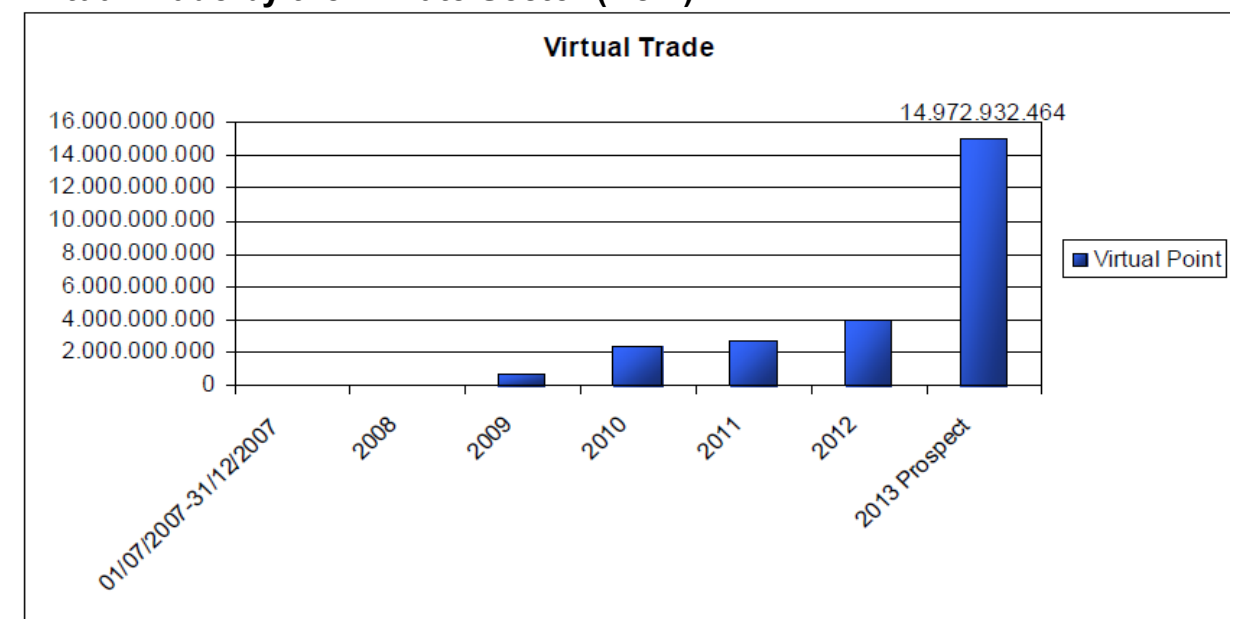

Source: BOTAŞ

${ }^{39}$ Deloitte (2012) (p. 32)

February 2014: Natural Gas in the Turkish Domestic Energy Market: Policies and Challenges 

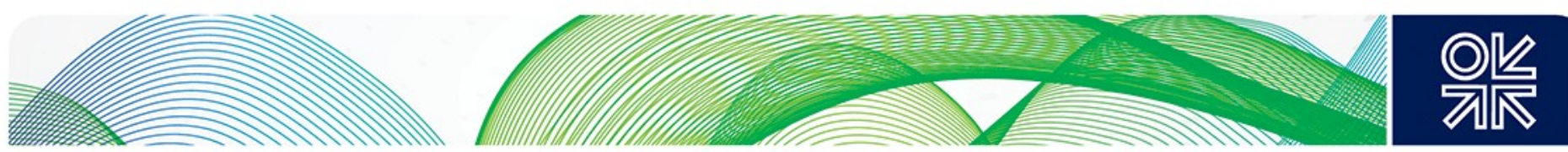

Figure 21: Total Virtual Trade

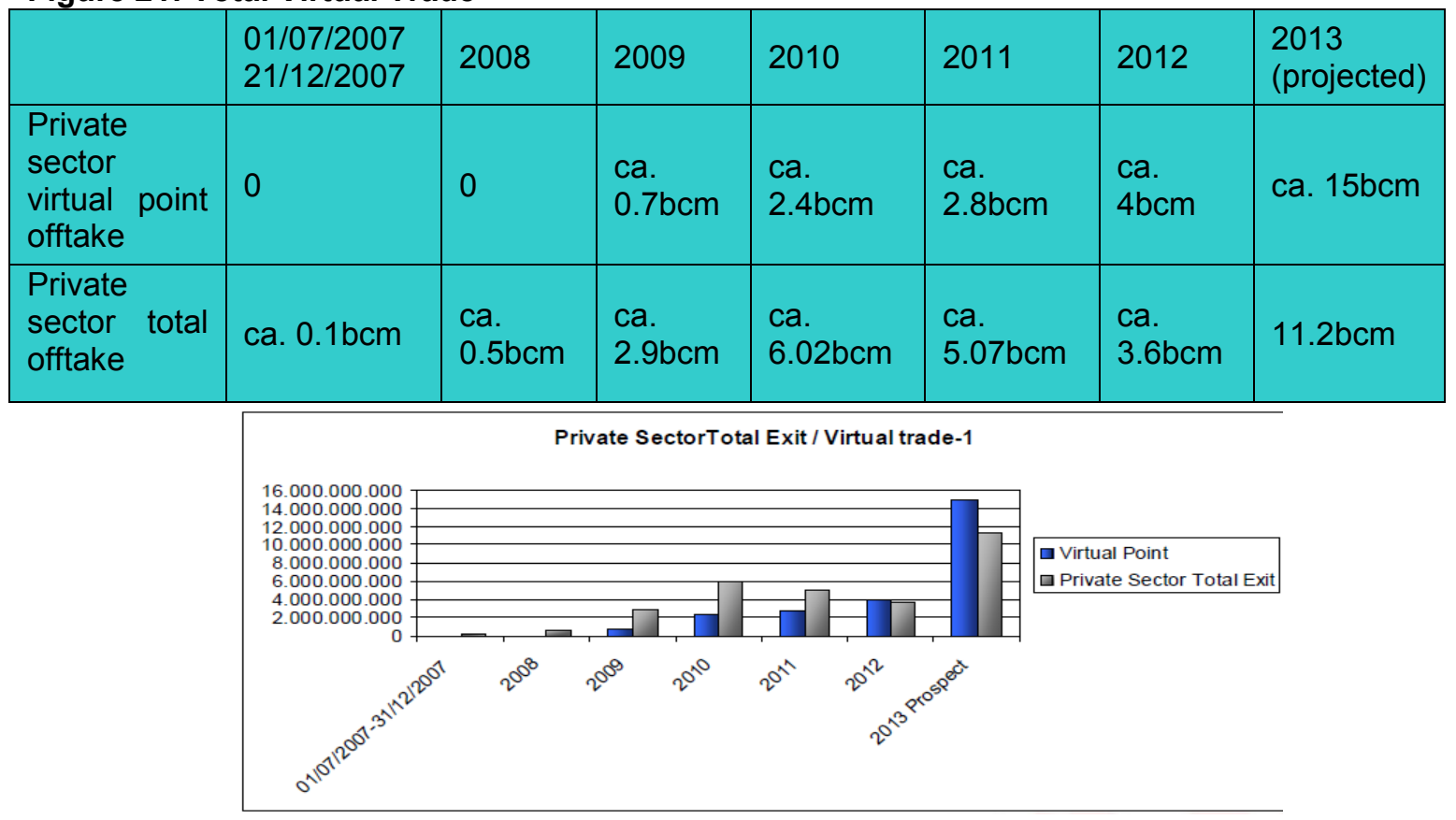

Source: BOTAŞ

\subsection{Underground Storage}

Because Turkey's domestic production is less than $2 \%$ of demand, and in order to prevent seasonal imbalances of supply and demand and avoid or reduce the negative effects of supply interruptions, it is necessary to increase storage capacity and daily withdrawal capacity.

Turkey has very limited underground storage capacity, which creates additional problems for BOTAŞ whenever it cannot take all the contracted volume during the summer or in May when there is the lowest demand and has to pay 'take or pay' penalties. Turkey also needs to increase underground storage capacity and daily withdrawal capacity to lessen the negative consequences of gas supply interruptions. Figure 22 shows that Turkey's storage capacity as a percentage of consumption is one of the lowest in Europe.

Figure 22: Storage Capacityas \% of /Total Consumption

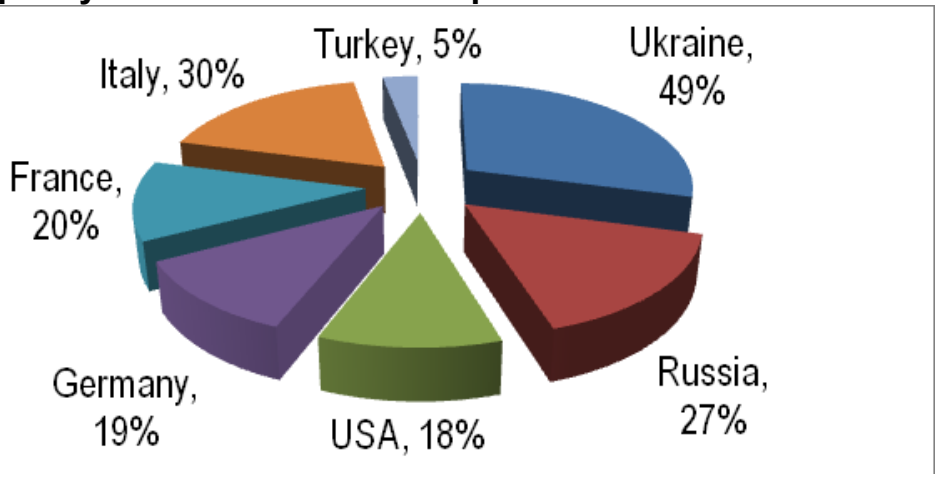

Source: SOCAR Turkey 

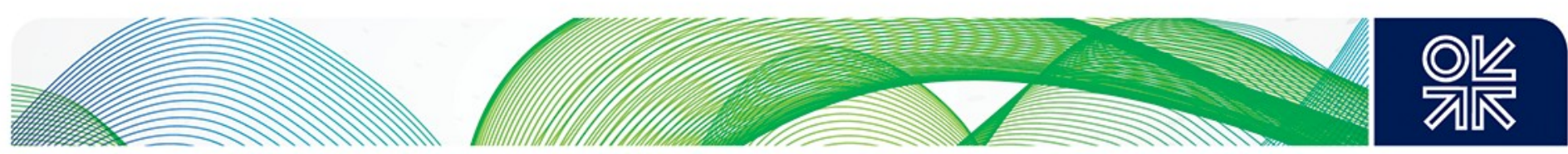

The only active underground storage facility is a gas field converted into an underground store by TPAO at Silivri in Degirmenköy. The maximum injection volume is $14 \mathrm{Mmcm} / \mathrm{d}$ and the maximum withdrawal rate is $17 \mathrm{Mmcm} / \mathrm{d}$ depending on the quantity and pressure of natural gas remaining in the store. TPAO as the owner of the store prepared the draft Principles and Procedures of Use for Silivri Underground Storage Facility which was opened to comments by related parties in June 2011. According to this, the draft initial $1.6 \mathrm{Bcm}$ of capacity allocated to BOTAŞ was increased to $2.1 \mathrm{Bcm}$ and it is planned to make an additional $561 \mathrm{Mmcm}$ available to third parties, in line with the EMRA 'Regulation on the Basic Use and Principles of Natural Gas Underground Storage Facilities' dated June 4, 2011.

TPAO has decided to increase Silivri storage output to the maximum production capacity of 50 $\mathrm{mmcm} / \mathrm{d}$, and agreed to increase the total storage capacity up to $2.84 \mathrm{Bcm}$ as well as to conduct feasibility studies to evaluate the use of the Batı-Sinekli and Degirmenköy-Osmancık fields as underground stores, at the request of MENR and other public bodies. The capacity expansion is planned in two phases.

TPAO is aiming to establish a new production facility at the Degirmanköy field - the Değirmanköy Storage Expansion and Environmental Natural Gas Project'(Phase-2) - with a maximum natural gas processing capacity of $10 \mathrm{Mmcm} / \mathrm{d}$. Total storage volume at Değirmanköy, with the possible use of natural gas reservoirs close to the field - Western Sinekliand Değirmenköy-Osmancık - may be increased to $587 \mathrm{Mmcm}$.

BOTAŞ is investing in the construction of Tuz Gölu (Salt Lake) salt cavern storage using water to be brought from Hirfanli Dam. The first tender was announced in 2009 and concluded in November 2011, when China Tianchen Engineering Corporation was awarded a contract. The project is planned to be completed by 2015-2016. A Certificate of the Environmental Impact Assessment (EIA) has been issued, the SPO has approved the feasibility study report, the basic engineering study is completed, the main equipment materials have been ordered, and detailed engineering work and drilling of the wells has started.

\section{North Marmara field storage expansion project (Phase III)}

This storage expansion project will be carried out by TPAO in the Northern Marmara field and includes the establishment of a new surface plant of $25 \mathrm{mmcm} / \mathrm{d}$ withdrawal capacity and $10 \mathrm{~mm} \mathrm{~cm} / \mathrm{d}$ injection capacity next to the existing natural gas storage facility at Silivri. The facility will be connected to the BOTAŞ main transport system branch by two 24 -inch pipelines. The total capacity of the processing facilities in the Northern Marmara field will be increased to $40 \mathrm{Mmcm} / \mathrm{d}$. The project will be completed by the end of 2016.

As shown in Charts 5 and 6, Turkey's peak seasonal demand is almost $200 \mathrm{Mmcm}$ and total daily capacity through pipelines, LNG and underground storage is $189 \mathrm{Mmcm}$, whereas total daily natural gas volume flowing into the system due to congestion is $178 \mathrm{mmcm}$ (Table 12). The investment and construction of new LNG facilities and increasing the capacity of underground storage facilities with the construction of the TuzGolu storage and expansion of the underground storage in North Marmara field and Değirmanköy project will help to solve the supply deficit during cold winter days. Also, BOTAŞ needs to solve the problem with the ToP obligations in its long-term contracts with the pipeline gas suppliers. 

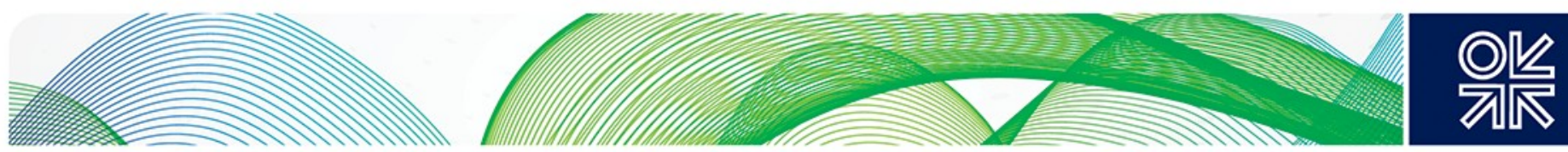

Table 12: Natural Gas Entry through Pipelines, LNG and Underground Storage Natural Gas Entry through Pipelines

\begin{tabular}{|l|l|l|l|}
\hline & $\begin{array}{l}\text { Transportation system entry } \\
\text { point } \\
\text { (by source country) }\end{array}$ & $\begin{array}{l}\text { Capacity } \\
\text { (mcm/d) }\end{array}$ & $\begin{array}{l}\mathbf{2 0 1 2} \\
\text { contract } \\
\text { (mcm/d) }\end{array}$ \\
\hline 1 & Malkoçlar (Russia-West) & $\begin{array}{l}\text { existing } \\
\text { volume }\end{array}$ \\
\hline 2 & Durusu (Russia-Blue Stream) & 41.4 & 39.6 \\
\hline 3 & Türkgözü (Azerbaijan) & 18.7 & 47.4 \\
\hline 4 & Gürbulak (Iran) & 28.6 & 18.7 \\
\hline Total & 146.1 & 28.6 \\
\hline
\end{tabular}

Natural Gas Entry through LNG

\begin{tabular}{|l|l|l|l|}
\hline $\begin{array}{l}\text { Transportation system entry } \\
\text { point }\end{array}$ & $\begin{array}{l}\text { Reservoir } \\
\text { capacity } \\
\text { (mcm/d) }\end{array}$ & $\begin{array}{l}\text { Transport system } \\
\text { entry } \\
\text { capacity(mcm/d) }\end{array}$ \\
\hline 1 & M. Eregllisi LNG Terminal & 153.0 & 22.1 \\
\hline 2 & Aliağa LNG Terminal & 168.0 & 16.1 \\
\hline Total & 321.0 & 38.2 \\
\hline
\end{tabular}

Natural Gas Entry through Underground Storage

Source:EMRA

\begin{tabular}{|l|l|l|l|}
\hline & $\begin{array}{l}\text { Transportation system entry } \\
\text { point }\end{array}$ & $\begin{array}{l}\text { Storage } \\
\text { capacity } \\
\text { (mcm/d) }\end{array}$ & $\begin{array}{l}\text { Transport system } \\
\text { entry } \\
\text { capacity(mcm/d) }\end{array}$ \\
\hline 1 & $\begin{array}{l}\text { K. Marmara - Değirmenköy } \\
\text { underground gas storage }\end{array}$ & 2.7 & 17.0 \\
\hline
\end{tabular}

Note: Total daily capacity is $189 \mathrm{mcm}$

Total daily gas volume inflow into the system due to grid congestion is $178 \mathrm{mcm}$

\subsection{Distribution}

Distribution in Turkey means delivery of natural gas to customers with a local transport and retail sale via the gas pipeline network. Local distribution of natural gas may be arranged by a company that wins the tender to be launched by the Authority and the duration of the license will be determined by the EMRA. Bids submitted by the companies are assessed according to the principles and procedures specified in the relevant legislation. The NGML provides that distribution companies can act as license holders, owners and operators in a maximum of two distribution regions across the country. However, because of the rapid development of consumption in a number of cities, capacity and numbers of users can be increased to more than 2 regions. Law No. 5367 dated June 16, 2005 has authorised the EMRA to increase this number ${ }^{40}$. The EMRA has allowed companies to operate in up to 22 regions in practice.

The bidding process run by the EMRA successfully opened the distribution segment in Turkey to the private sector. As a result, the number of cities which gained access to natural gas increased from 6 in 2003 to 65 in 2012. The only criterion in the tender is the bidding compnaies' commitments on distribution cost. The distribution charges consist of unit service and depreciation charges, which are

\footnotetext{
${ }^{40}$ NGML 4646 (Law to the Amendment) Law No.: 5367, Adoption Date: 16.06.2005, available in Turkish at http://www.epdk.gov.tr/index.php/dogalgaz-piyasasi/mevzuat?id=50
}

February 2014: Natural Gas in the Turkish Domestic Energy Market: Policies and Challenges 

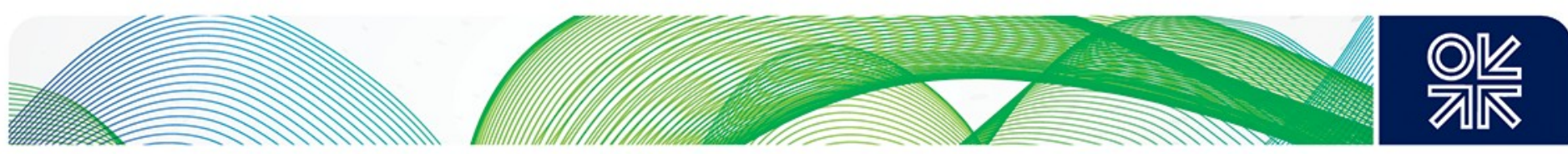

valid for 8 years. The number of companies that completed the first tariff period of 8 years reached 22 by the end of $2012 .^{41}$

One company can be granted a license for distribution activity for the duration of 30 years and may transfer its license to a third party during this period with the approval of the EMRA. In order to facilitate competition in the wholesale market, the distribution license requires that distribution companies can only buy a maximum of half their natural gas purchases from a single company. This has not worked out in practice, since BOTAŞ still holds a very high market share.

A company that has received a distribution license as a result of a bidding process is required:

1. to start investment within the first 6 months;

2. to have made at least one connection within the first 18 months, and

3. to connect all requesting consumers to the system within the first 5 years.

The latter depends on the economic and technical feasibility of connection and adequacy of system capacity.

Until the end of 2012, the total investment by distribution companies in distribution activities exceeded TL 3.2 billion (excluding VAT). Investment by the companies holding distribution licenses as a result of the tender is shown in Figure 23 (not including VAT only for 2012).

\section{Figure 23: Total Investment by Tender Licensee Companies (TL million)}

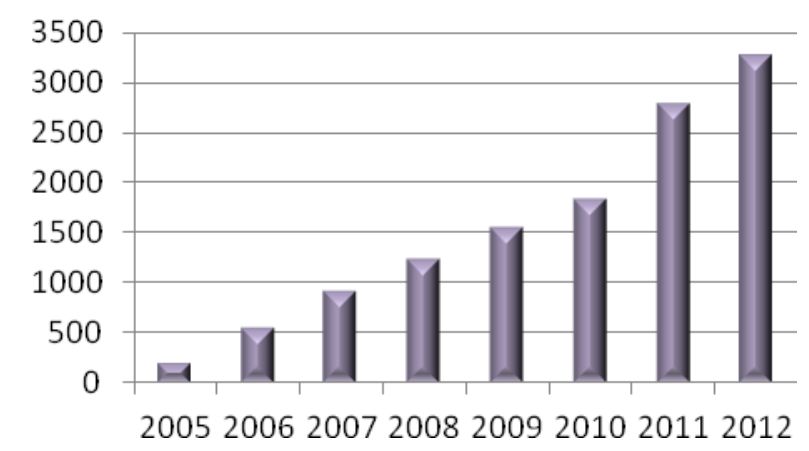

Source: EMRA

According to the decision of the Board No. 1955 dated January 29, 2009 the EMRA is monitoring the companies that obtained distribution licenses. This is carried out within the tender's terms and specifications that require certain guarantees on the fulfilment of five-year investment obligations, within the scope of the license. The privatization of the natural gas distribution sector has been fulfilled successfully so far despite the fact that BOTAS still has the lion's share of the wholesale market. As a result of this process very significant investment was attracted to the system and rapid expansion of the distribution network has occurred. There has been an increase in the number of regions where natural gas is distributed by private companies.

\footnotetext{
${ }^{41}$ Deloitte(2012) (p. 45), http://www.deloitte.com/assets/Dcom-

Turkey/Local\%20Assets/Documents/turkey $\operatorname{tr}$ energy naturalgas 030512.pdf
} 

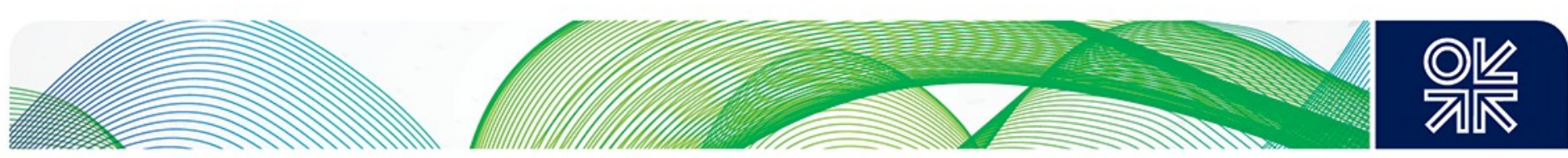

\section{Transit Projects}

Turkey's favourable geographical position between $47 \%$ of the world's proven energy resources, in Russia, Azerbaijan, Turkmenistan, Uzbekistan, Kazakhstan and Iran, and $17 \%$ of global natural gas consumption in Europe ${ }^{42}$ makes this country important both from the political and economic point of view in the international energy arena.

Turkey is prioritising its own interests - to secure gas for its own market and to pursue its aim of becoming a hub - which are not always in line with EC policies on the realisation of the fourth energy corridor project or the so-called Southern Gas Corridor (SGC). This is envisaged to open a new route for natural gas from mainly the Caspian Sea region as well as from the Middle East primarily Iraq. New discoveries in the Eastern Mediterranean have recently shifted the focus area. All these efforts are aimed to provide more diversified supply routes, but especially to secure new gas sources to flow directly into Europe.

Turkey's domestic energy situation plays an important role in the development of the Southern Gas Corridor and no doubt contributes in the bilateral relationships. Turkey's willingness to transit Caspian natural gas through its territory is a key to progress in the SGC. This is because Turkey's domestic natural gas market could, over the long term, absorb most of the gas volumes available for export from Azerbaijan. From the second phase of the Shah Deniz project, $6 \mathrm{bcm} / y e a r$ will go to Turkey and $10 \mathrm{bcm} /$ year will be sold to European buyers. But some additional volumes of future generation fields in Azerbaijan could be delivered to the Turkish market in the future. Also, there are prospects of further natural gas supplies from the Middle East (Iraq), Eastern Mediterranean (Israel), and other suppliers. For the SD2 partners, Turkey is a lucrative market currently with a high netback margin because of the short transportation distance and prices close to the European average price.

\subsection{TANAP (Trans-Anatolian Natural Gas Pipeline)}

The only realistic new natural gas supply project from the natural gas-rich countries surrounding Turkey, is expected in the medium term to be from Azerbaijan - the Southern Gas Corridor's supply anchor. Unlike the uncertain prospects for supplies from Iraq's Kurdish region, Azerbaijan and Europe have finalised all the necessary political and legal bases. The Trans-Anatolian Natural Gas Pipeline (TANAP) project is now considered as the backbone of the Southern Gas Corridor replacing the now defunct Nabucco Classic pipeline.

The signing ceremony of the Azerbaijan-Turkey transit contract was witnessed by the President of Azerbaijan Ilham Aliyev and the Turkish Prime Minister Tayyip Erdoğan on October 21, 2011. TANAP paved the way for the implementation of large-scale projects in the region and has been considered as a kind of revival of the ancient Silk Way route.

The formal process of the implementation of the project started on June 26, 2012 with the signing of the Intergovernmental Agreement (IGA) and the Host-Governmental Agreement (HGA) in Istanbul. It was the most significant development milestone of the Southern Gas Corridor since 2009.

The TANAP project is designed initially to transport SD2 gas, and then next generation gas volumes from other fields in the Azeri sector of the Caspian after 2020. Azerbaijan expects to double its current gas production to $50-65 \mathrm{Bcm} / \mathrm{y}$ between 2025 and 2030 .

\footnotetext{
${ }^{42}$ BP Statistical Review of World Energy 2013, http://www.bp.com/content/dam/bp/pdf/statisticalreview/statistical review of world energy 2013.pdf
} 

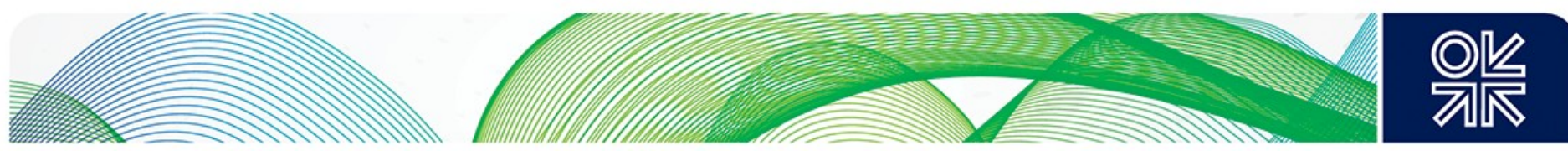

The TANAP will be connected to the expanded Southern Caucasus Pipeline Expansion (SCPX) on the Turkish-Georgian border constituting one integrated system. TANAP will stretch throughout Turkish territory and terminate on the Turkish-Greek border. In Turkey, the TANAP will pass through 21 regions - Ardahan, Kars, Erzurum, Erzincan, Bayburt, Gümüşhane, Giresun, Sivas, Yozgat, Kırşehir, Kırıkkale, Ankara, Eskişehir, Bilecik, Kütahya, Bursa, Balıkesir, Çanakkale, Edirne, Tekirdağve, Kırklareli- and will be able to transport approximately $73 \%$ of annual Turkish domestic natural gas consumption (See Map 5). This amount exceeds the annual imports from Russia, and will affect Russia's future market shares not only in Turkey, but also in its traditional European market.

\section{Map 5: The Trans-Anatolian Natural Gas Pipeline Project}

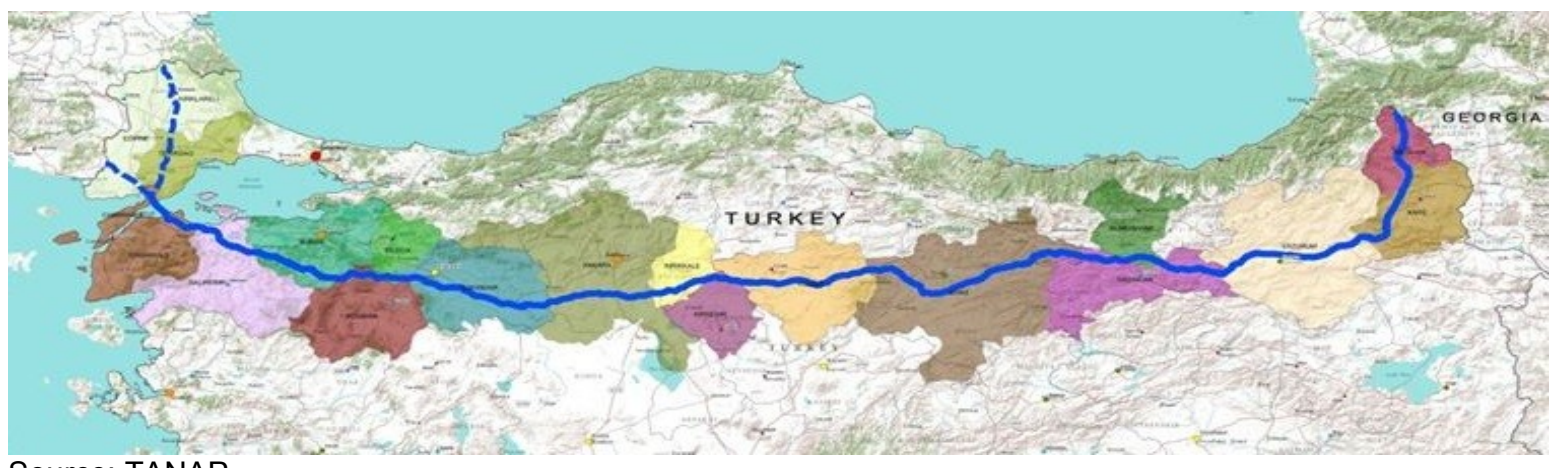

Source: TANAP

The length of the pipeline from the Georgian border up to the border with Greece is $1,541 \mathrm{~km}$. The pipeline is designed to be scalable with a 56 " diameter. It is planned to transport $16 \mathrm{Bcm} / \mathrm{y}$ in the first stage of operation. Of this $6 \mathrm{Bcm} / \mathrm{a}$ will be transported to Thrace Region and Eskişehir, where the gas will be connected to the BOTAŞ transmission network for domestic consumption. The total transportation capacity of the line will be increased in the second stage of operation up to $23 \mathrm{Bcm} / \mathrm{y}$ in 2023 and to a capacity of $31 \mathrm{Bcm} / \mathrm{y}$ by 2026 . For this, the construction of $7-8$ high pressure compressor stations is planned.

In 2012, the TANAP project company completed work on route identification, the Environmental Impact Assessment (EIA) report conducted by Çinar consulting company, the front-track report conducted by SEBAT consulting company, and the technical feasibility assessment report conducted by international consultant company GIE.

A tender for engineering works has been announced. 'Project Management and Client Engineer Company (PMOE-ILF)' won the tender in July 2012 and it has been assigned to lead the project. From the technical point of view Turkey will benefit significantly: high class and modern infrastructure, know-how and technologies will be brought to the country, and further development of local technical staff will be secured.

It is expected that the pipeline construction and commissioning will start in Q2 of 2015 and will be completed by Q3 of 2018, when SD2 gas is scheduled to flow for export to the Turkish and Italian markets via the TAP pipeline (See Figure 24). 
Figure 24: The TANAP Project Schedule Overview

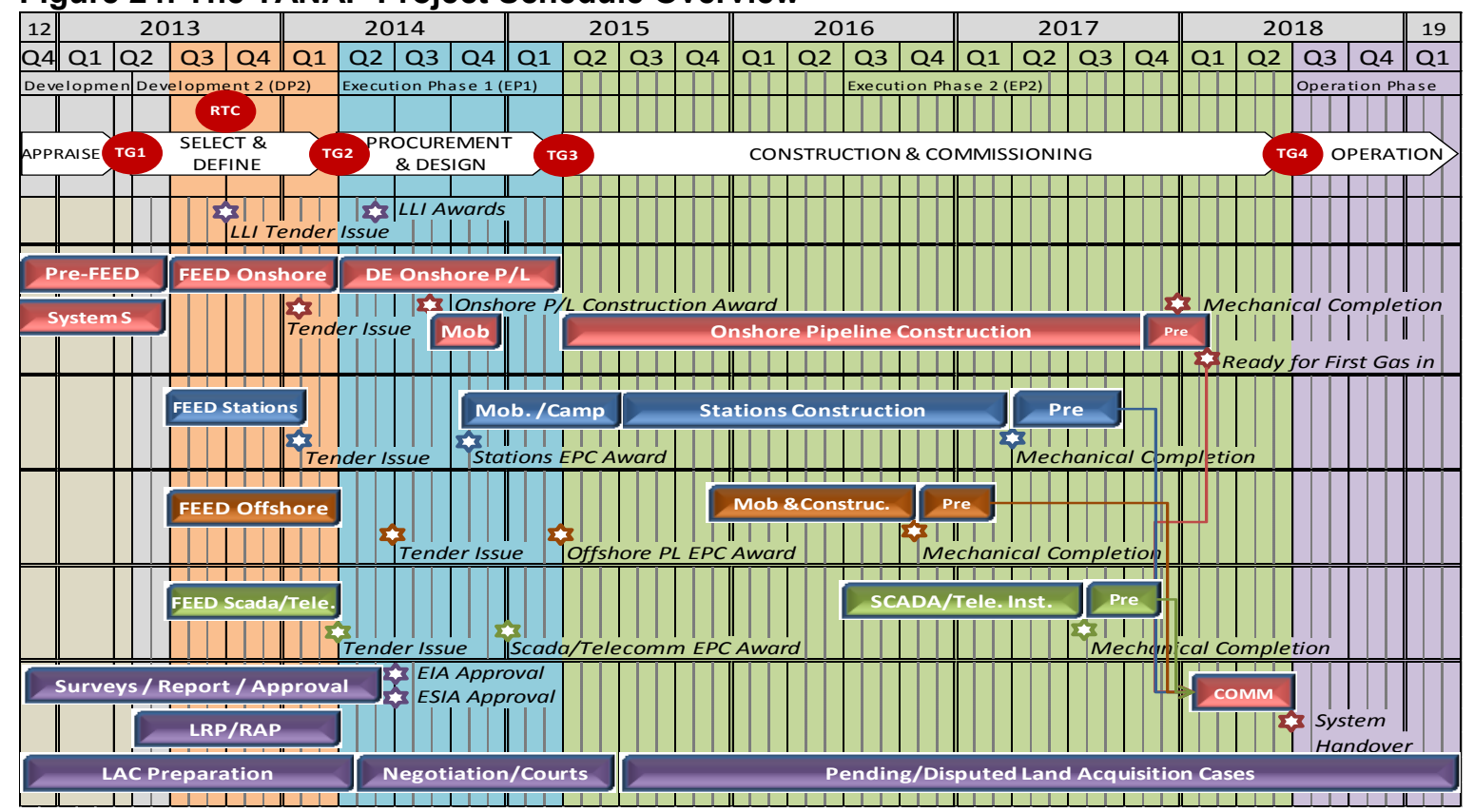

Source: TANAP

Before the TANAP project was initiated, BP promoted another option, to transport Azerbaijani gas from SD2 using BOTAŞ's existing transport system, and thought to be less expensive than building a new standalone pipeline.

The BOTAŞ transport system has little spare capacity especially east of Ankara for transporting bigger natural gas volumes coming from Azerbaijan and other sources (See Map 6).

Map 6: East-West capacity through Turkey by building a dedicated pipeline

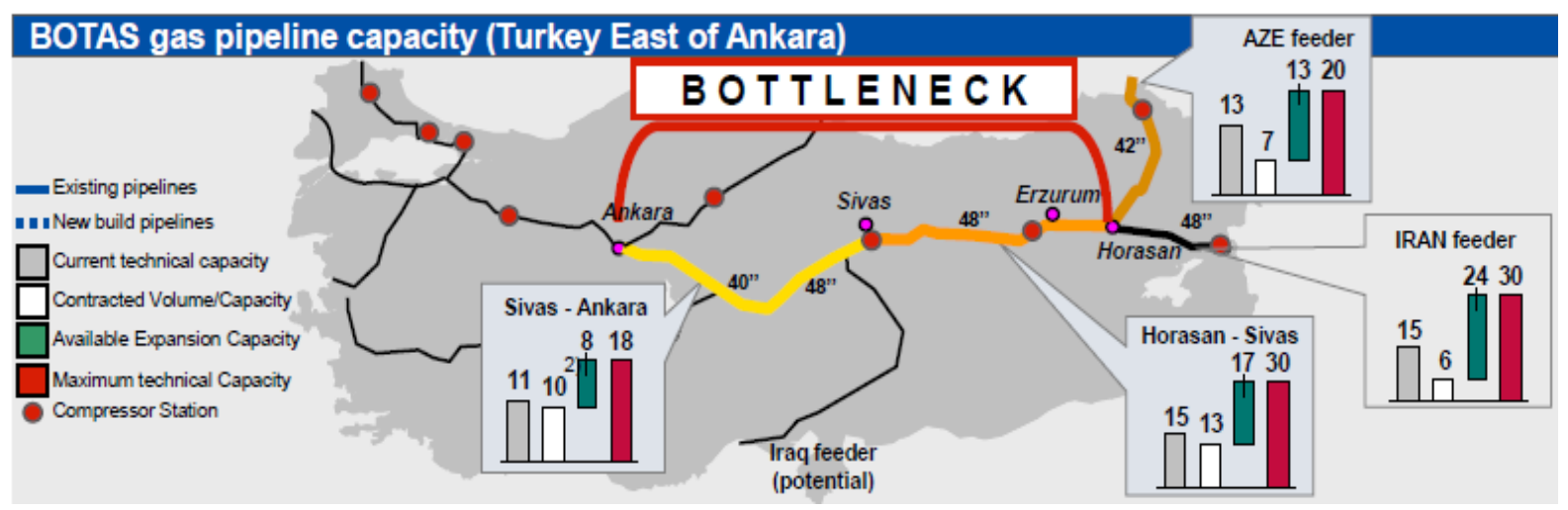

Source: RWE

Additionally, during peak winter demand the system capacity is not sufficient to increase the volume of transportation. To avoid that bottleneck, additional investments for expansion of BOTAŞ's transport system would be needed, but the expansion of the existing BOTAŞ transport system would be much cheaper than constructing a dedicated pipeline.

However, having in mind next generation of fields, which are currently at different stages of development, the leadership of Azerbaijan and SOCAR decided in favour of the TANAP option. By doing so, Azerbaijan took the initiative and responsibility to pave the way for other Caspian neighbours to have a choice to link their resources directly to the liberalised European market. With

February 2014: Natural Gas in the Turkish Domestic Energy Market: Policies and Challenges 

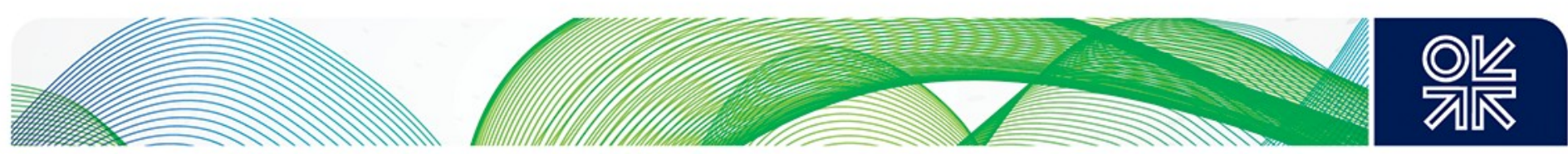

TANAP in place Turkey itself would be able to import more gas from Iran and potential new suppliers such as Iraq, Israel, Lebanon avoiding the bottleneck in the BOTAŞ transport system from Horasan to Ankara (See Map 6).

The political benefits for Turkey of the TANAP are obvious. The project will contribute significantly to the growing political role of Turkey in the broader context of Europe, the Black Sea, the Caspian Sea, the Middle East and Mediterranean regions by making the country a strategic partner and an important transit country. Turkey will thus realise its long-term strategic objective to become an important energy bridge between hydrocarbon rich eastern suppliers and energy importing European markets. Eventually, Turkey's geographical location and emergence as an energy hub for Europe could contribute to acceleration in the EU membership negotiations.

Initially TANAP equity was divided between SOCAR (80\%), BOTAŞ (5\%) and TPAO (15\%). At the time of writing, negotiations have been completed between SOCAR and BP to join the project with the equity share split as following: SOCAR (67.5\%), TPAO (15\%), BOTAŞ (5\%), BP (12.5\%),. The SD2 partners have insisted on veto rights over the decisions SOCAR will take about technical and financial issues as project operator. As a result of the negotiations SOCAR refused to grant the veto right to the partners and TOTAL and Statoil did not want to join the project without such rights.

BOTAŞ has low equity in the project because it has financial difficulties and a low credit profile. However, it is expected that the equity shares of BOTAŞ and TPAO will be increased to $30 \%$.

It may seem that for the country that is targeting a role as gas hub for Europe having only a $30 \%$ share in the most important and strategic transit project is very modest. Nevertheless, this share is more than the $16 \%$ BOTAŞ would have had in the Nabucco Classic pipeline project and TANAP could fulfil the same tasks for Turkey. The benchmark of the equity allocation for Turkish companies was their shares in the Nabucco Classic pipeline project.

Although from the beginning it was suggested that the pipeline should be managed based on Swiss law, later in January 2013, it was decided by the Turkish and Azerbaijani government that TANAP should be managed under Turkish Law. ${ }^{43}$ If any dispute should occur, the case will be taken to the Turkish courts.

This gives Turkey the additional benefit of being able to control the legal processes. Also, it would give Turkey a means of financial control. This means that all the revenues generated by the project will be regulated by Turkish law including various taxes, duties and other payments.

According to publicly available data, it is estimated that TANAP will cost $\$ 11-12$ billion. SOCAR will finance the lion's share $-56.5 \%$ (if and after Turkish companies BOTAŞ and TPAO acquire additional $10 \%$ ). It is expected that the funds will be allocated from the State Oil Fund of Azerbaijan (SOFAZ).

It is unlikely that shareholders will receive large profits at the first stage of the operation of the pipeline. However, revenues will increase once additional natural gas volumes from the next generation of fields flow through the pipeline. Further financial benefit would be generated if Iraqi and/or eventually Israeli gas was transported through TANAP.

Also, during the construction phase, local work forces will be employed and local banks could play a lender role if the project finance model is the classic 30\% (company equity in the pipeline consortium) / 70\% (loans).

On the other hand, for BOTAŞ it would be cheaper to import its $6 \mathrm{Bcm} / \mathrm{y}$ of gas from SD2 starting from 2018, via its own infrastructure rather than TANAP. The transportation costs, according to calculations by industry sources will be no less than $\$ 70-80 / 1,000 \mathrm{~m}^{3}$. It was important to include $6 \mathrm{Bcm} / \mathrm{y}$ of gas to

\footnotetext{
${ }^{43}$ MENR Activity Report 2012, pp. 31. Available in Turkish at:

http://www.enerji.gov.tr/yayinlar_raporlar/2012_faaliyet_raporu.pdf
} 

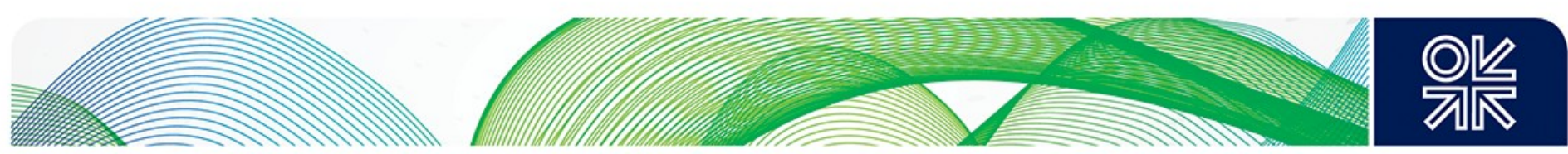

be transported to the Turkish domestic market in the TANAP to secure the pipeline's economical operation ability by functioning at full capacity in the first stage.

The TANAP project would definitely contribute significantly to Turkey's ambition to become an energy hub if Turkey/BOTAŞ could have received re-export rights. However, for now the TANAP pipeline has completely changed Turkey's strategic policy, making it an important transit country. Turkey will also be able to import natural gas from alternative sources for its own purposes.

Turkey is becoming a backbone of the entire SGC with TANAP stretching through its territory. In the fully liberalised Turkish natural gas market, Turkey's participation in regional transportation projects will help eventually to secure gas supplies from other sources to lessen possible natural gas supply shortages in the medium term, especially during winter peak demand days. These additional supplies will help fill pipelines running through Turkey to a maximum level, making the country the only viable transit route, while at the same time maximising transit service revenues for Turkey.

\subsection{TAP (Trans-Adriatic Pipeline)}

Another important project that will significantly contribute to the growing importance of Turkey as a transit country is the Trans-Adriatic Pipeline (TAP) pipeline.

TAP was selected over the scaled-down Nabucco West project (NW) by the SD consortium in June 2013. The decision was based on the well-known 8 criteria the SD consortium set at the beginning of the pipeline 'beauty contest' to transport SD2 gas to European markets. TAP will transport SD2 gas onward from the Turkish-Greek border to Greece, Albania, and across the Adriatic Sea to Italy.

It is understandable that Turkey would be more interested in having Nabucco West (NW) selected over TAP because of the BOTAŞ shareholding in that project and the strategic value of the pipeline. However, TAP has a number of advantages over NW including its shorter length, the initial diameter of 42 inches and consequently lower transportation costs and capital investment.

NW lacked developed project financial proposals and its cumbersome managerial structure created difficulties in conducting negotiations. From the political point of view Azerbaijan, with its oil major SOCAR having a key position in decision-making in the consortium did not get the expected political support from Brussels and eventually from Washington. Both these parties officially expressed neutral positions vis-a-vis the projects.

The TAP project expects to secure project financing from a number of multilateral institutions, such as the European Bank for Reconstruction and Development and the European Investment Bank, as well as Export Credit Guarantee Agencies, and it has already received Letters of Intent from these agencies. TAP is scalable from $10 \mathrm{Bcm} / \mathrm{y}$ to $23 \mathrm{Bcm} / \mathrm{y}$, plus reverse flow capacity and a gas storage option in Albania.

TAP's main destination, Italy, provides a solid natural gas market, the second-largest in continental Europe, historically offering relatively high prices compared to other major European hubs. This makes Italy a natural choice to underpin the Southern Gas Corridor.

One of the important criteria of the SD2 consortium was the opportunity that the pipeline of choice would provide access for as many additional markets as possible, offering greater flexibility. One of the most important markets on the route of the TAP is the Western Balkans, which is entirely reliant on Russian gas. TAP offers flexibility from its agreements with various energy companies and governments in the Balkan region: bilateral agreements on IAP (Ionian-Adriatic Pipeline) and TAP have been signed with Plinacro (Croatia) in February 2011, BH-Gas (Bosnia-Herzegovina) in April 2011, the Government of Montenegro in May 2011, the Government of Albania in July 2011, and Geoplin Plinovodi (Slovenia) in September 2011. In addition, the governments of the Western Balkans have demonstrated their strong support for the TAP project and the connection with the IAP pipeline through a range of intergovernmental declarations and MOUs. 

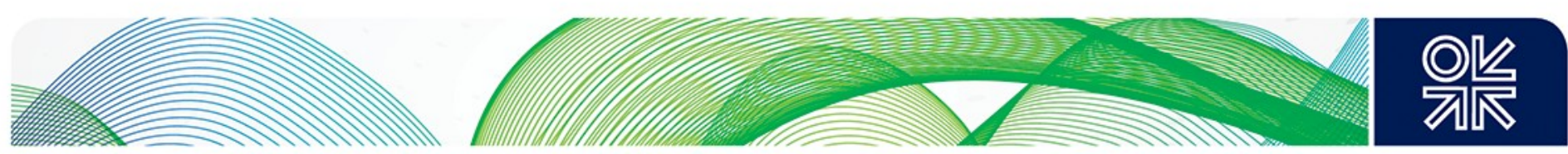

By connecting to key infrastructure such as the Ionian Adriatic Pipeline (IAP) and the Western Balkan Ring, TAP can bring new gas supplies to countries such as Albania, Bosnia and Herzegovina, Montenegro and Croatia - markets that currently depend on a single natural gas source or do not have access to gas at all.

The SD partners are in the negotiation stage to enter the TAP project as a shareholder and the pipeline shareholder structure could eventually be: BP, SOCAR, Statoil $(20 \%$ each), Fluxys $(16 \%)$, Total $(10 \%)$, EO.N $(9 \%)$, Axpo $(5 \%){ }^{44}$ BOTAŞ has already expressed its aim to have a share in the project at the expense of reducing the share of any of the participating companies. E.ON would be a potential candidate to further reduce its share in TAP in return for a market share in Turkey.

\subsection{Turkey's Potential to Become an Energy Hub}

Turkey has long had a vision of becoming an energy hub. The first transit negotiations Turkey had were with Qatar which wanted to provide transit via pipeline for Qatari gas production volumes to European countries. However, the negotiations did not yield positive results and Qatar chose the option of exporting its gas in the form of LNG.

Turkey also discussed the transit of Turkmen gas in 1992. Turkey proposed the Trans-Caspian Natural Gas Pipeline project, but this turned out to be fraught with difficulty because of the political dispute between the littoral states over the delimitation of the Caspian. Despite the extreme complexity of this issue Turkey has shown its constant intention to import and transit Turkmen gas, and a Heads of Agreements to import $16 \mathrm{Bcm} / \mathrm{y}$ of Turkmen gas was signed in 1999. At the beginning of 2013, Turkish president Abdullah Gül during his visit to Ashgabat said that Ankara was still aiming to import and transit Turkmen gas, and if the negotiations between Azerbaijan, Turkmenistan and the European Commission did not yield any result, then Turkey would consider other options including transporting the gas through Iranian territory.

Turkey is also a potential transit country for gas from Iran, which has the second largest natural gas reserves after Russia. Iran has encouraged many countries, including Turkey, to make efforts to allow the transit of larger volumes of Iranian gas towards Europe. In 2007, Turkey signed an MOU with Iran on investing $\$ 3.5$ billion in the development of three phases of the giant offshore South Pars field in the Iranian sector of the Persian Gulf. However, these negotiations failed, as a result of the financial sanctions imposed on Iran by the US and supported by the EU.

Considering the diversity of the supply sources surrounding Turkey and the routes by which Turkey currently imports gas for its domestic consumption as well as the LNG and storage capacity expansion potential, Turkey's vision of becoming a 'gas trading hub' is quite realistic - although only in the long term, given the speed of market reform.

Within Turkish legislation there are provisions defining two opposite models: 'Transit' and 'Re-Export', as market activity does not have separate transit legislation that would be in compliance with the EU Energy Charter Treaty. Furthermore, the're-export' clause is not included in the transit agreement with Azerbaijan, the only country for which Turkey transits gas. A hub model for Turkey would include regulations that would enable Turkey to import gas from neighbouring countries into the Turkish gas pool through private companies or through active involvement in production areas and to re-export it to the European market. In this case the sales and purchase agreements should not prohibit the reexport of the gas by the supplier.

Turkey could become either:

- A physical gas trading hub, with import and export pipelines, connections with other physical hubs mainly via interconnectors, access to storage and gas title transfer among actors trading; or

${ }^{44}$ Fluxys joins TAP project, http://www.fluxys.com/group/en/NewsAndPress/2013/130730 Press TAP

February 2014: Natural Gas in the Turkish Domestic Energy Market: Policies and Challenges 

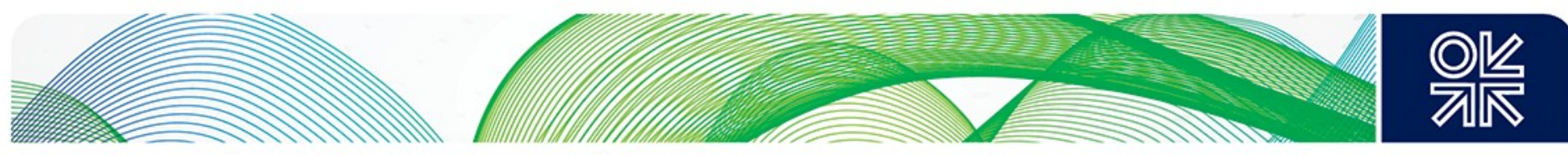

- A commercial hub with bilateral and broker-based trading, a balancing mechanism that takes market-based price formation as a basis as well as exchange trading, futures and financial derivative transactions, referring to a virtual point or a physical gas hub ${ }^{45}$ similar to the NBP in UK or the TTF in the Netherlands.

Turkey as a country surrounded by potential resources and most importantly neighbouring the EU with its declining domestic production, can potentially trade up to $100 \mathrm{Bcm} / \mathrm{y}$ of gas in the long run. This could be realised once the large-scale investments in infrastructure have taken place, including new LNG facilities and the expansion of storage capacities. However the necessary legislation framework is missing and Turkey would need to prepare the legal framework explicitly defining the transit regime as well as trading operation on a natural gas hub.

The priority issue would be to unbundle BOTAŞ's transport and wholesale businesses. The issue of institutional reforms within the process of liberalizing energy market is reflected in the Draft Amendments to the new Electricity Market Law No. 6446, Article 11. It deals with the establishment of an exchange energy markets operation Inc. (EPIAŞ) in Turkey, which will be converted later to an Energy Exchange Inc. Initially, it would work for the electricity market but could eventually include natural gas, coal, oil and carbon. Establishing a separate Turkish Natural Gas Exchange, or Petroleum Exchange, as a new Energy Exchange in the region has also been targetted. These, once established, would work as sub-markets.

The establishment of a commercial energy exchange market in Turkey's energy sector should be based on the principles of reliability, transparency and liquidity and market price dynamics.

Because of its social and physical geography, the internal dynamics of Turkey require dynamic and transparent functioning of the energy market. The 'energy exchange' is one of the most important steps to be taken in this direction. Another option for Turkey, instead of being an energy corridor or bridge, is to be a centre for commodity markets, where all of the region's electricity and gas would be traded. To realise its significant potential of being the largest energy consumption market in the region, the establishment of Turkey's own internal dynamics, mechanisms and legal framework will be needed. That will ensure a reliable reference on which to base price provisions in contracts with foreign investors, not only in Turkey but also investors and stakeholders from the Caspian Sea and Middle East regions.

For Turkey, the establishment of such an exchange in these markets could turn out to be a decisive factor. It is very important for security of energy supply to find the "right price". An energy trading market, with the axis of the right price, will contribute positively to increasing the country's trade volume, and will open the way for investments in medium-and long-term energy projects.

In energy markets the determination of the price structure based on market dynamics driven by supply and demand, will not only establish a secure market for all stakeholders, but will also contribute to define a price in the regional centre. With the proper functioning of the energy exchange, both consumers and producers can only benefit from the ability to manage price risks. The exchange market will also provide with a predictable pricing mechanism for banks and financial institutions which will also help to provide better funding conditions. The energy market developing in this way will create employment and added value, and will rid the public energy sector of large financial burdens.

Such a confidence-building environment will accelerate foreign energy investments, which could help to reach the $\$ 100$ billion energy investment needed by the country by 2023 .

However, the development of a liquid gas trading hub will be difficult if the majority of gas coming into Turkey continues to be under long term contracts oil indexed prices. For the hub vision to be realised,

\footnotetext{
${ }^{45}$ Deloitte 2012), http://www.deloitte.com/assets/Dcom-

Turkey/Local\%20Assets/Documents/turkey $\operatorname{tr}$ energy naturalgas 030512.pdf
} 

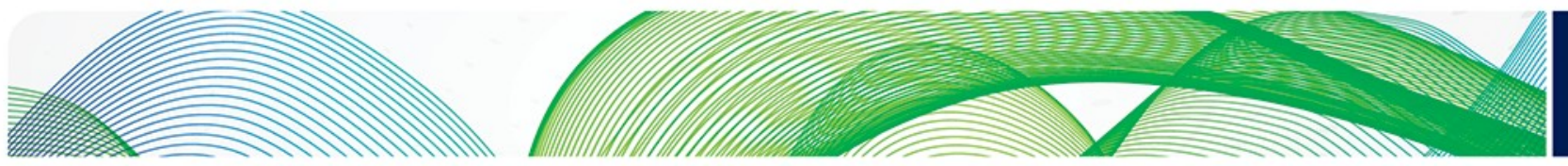

\section{OVK}

there needs in time to be sufficient spot gas traded in Turkey to form a reliable price index. Suppliers would migrate from oil indexation to this traded price index for long-term contracts. 

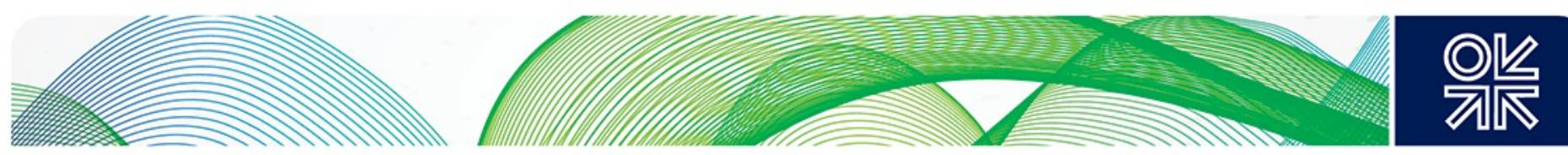

\section{Conclusions and Recommendations}

The Conclusions are drawn from the key areas this paper covers, which mainly include:

- The level of domestic demand,

- the role of price in setting demand,

- how Turkey's import requirement will change,

- the progress (or lack of progress) of gas market liberalization policies.

The main reason why the Turkish government originally suggested opening the market to competition was steeply growing natural gas demand mainly driven by demand in power generation. According to BOTAŞ and the EMRA, Turkey's natural gas demand will grow from the current $47 \mathrm{Bcm} / \mathrm{y}$ to $81 \mathrm{Bcm} / \mathrm{y}$ in 2030, empowering private companies competing with each other and BOTAŞ to bring more natural gas from diversified sources at more competitve prices.

Consequently, the government's number one concern with the changing market and all its uncertainties is whether it will be able on an economically sound basis to provide a secure supply of natural gas in an increasingly competitive domestic wholesale market, and meet the growing demand.

Although the government aims to reduce the share of natural gas in power generation from the current $45 \%$ to $30 \%$ by 2030 , through a number of measures described in this paper, the overall volume of natural gas consumption in power generation will increase as a result of steeply growing (6$7 \% / y)$ per capita power consumption. The main factors that could cause the failure of the government policy to reduce the share of gas are:

a) EMRA is continuing to grant licenses to private companies to build more gas-fired power plants. New natural gas-fired power plants would require an additional $70 \mathrm{Bcm} / \mathrm{y}$ of gas supply if all become operational at high load factors.

b) If Turkey is able to negotiate a better price for imported pipeline gas with its suppliers, there will be less incentive to enforce the policy of reducing the share of gas in the electricity sector.

c) Turkey can join the European Union Emission Trading Scheme to combat climate change as early as 2016. As a result, the generation companies will have to report their carbon footprints. Additionally domestically produced coal and lignite have very low calorific values which further undermines their attractiveness.

The main driver of demand growth or decline in Turkey's energy profile in general and the power generation in particular is the price. For BOTAŞ, which sells natural gas at subsidised prices for generation, and for the government which subsidizes natural gas for residential customers, it is increasingly burdensome to buy natural gas for a high price and sell it for lower prices.

When and if the gas price is high, Turkey will try to replace it with different fuels, in the case of power, mainly by nuclear, domestically produced hard coal and lignite. Although the role of renewables is growing, it has not yet reached a level sufficient to substitute significantly for fossil fuels.

In section 2 above, it was suggested that overall Turkish gas consumption will rise from $47.6 \mathrm{bcm}$ in 2013 to $70 \mathrm{bcm}$ in 2030, with the main driver being consumption in the power sector, which will rise to 

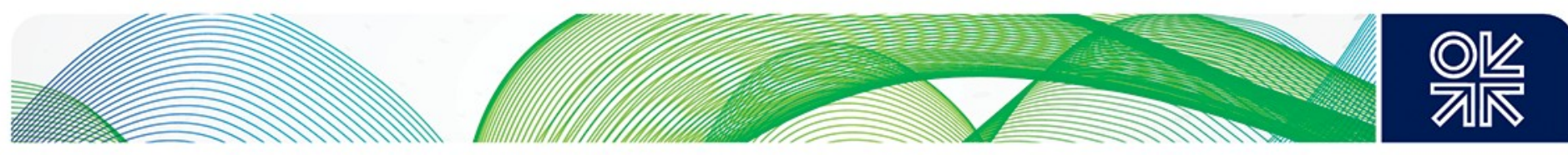

30-33 bcm/year. Clearly the price and other factors mentioned may influence demand growth upwards or downwards from these levels.

In light of these points, and considering the demand forecasts and the development of supply based on existing contracts and future contract volumes at the plateau levels, it is estimated that Turkey could be in supply deficit from 2016-2017. Thus, Turkey might not be able to meet the peak demand during the winter days, before SD2 gas is exported to Turkey from Azerbaijan (currently expected to be 2018). This could partly be caused by the possibility of reduced LNG imports due to price pressures and limited capacity of LNG facilities, making LNG a risky competitive environment for private companies. In these circumstances Turkey would have to increase the volume of gas imported from Russia if Iraqi gas did not come online after 2016 due to obvious political tensions.

On the supply side, it is estimated by BOTAŞ that by 2027 Turkey will need to import an additional 10 $\mathrm{Bcm} / \mathrm{y}$, and it is not clear where this could come from. The private companies that currently have an import portfolio of around $10 \mathrm{Bcm} / \mathrm{y}$ from Gazprom via the Western Line are concerned at the potential risk that Gazprom might not renew the contracts when they expire because they pay less for Russian gas $\left(\$ 350 / 1000 \mathrm{~m}^{3}\right)$ than BOTAŞ $\left(\$ 429 / 1000 \mathrm{~m}^{3}\right)$. To mitigate those risks, some of the importing private companies (Akfel and Avrasiya Gas) have Gazprom ownership participation, to encourage a long-term export-import partnership.

Needless to say, all the contracts currently in operation need to be renewed by private companies to avert an overall supply shortfall, especially during peak winter demand. The other important measure should be to increase the LNG import capacity and LNG import volumes (both within contract and spot trade) in order to have enough gas available in force majeure situations. Peak winter demand sometimes exceeds daily maximum supply and needs to be supplemented with withdrawals from LNG terminals and underground storage facilities. Improvements to TPAO's Silivri and Degirmenköy Underground Gas Stores need to be completed by the target year of 2016.

Turkey has developed a long-term strategy to import gas from Iraq (primarily the Kurdish northern areas), Israel, and Turkmenistan. Further potential lies in the next generation fields offshore in Azerbaijan. The sales and purchase agreements for importing additional volumes of natural gas from those countries can help solve the country's future supply shortfalls and turn it into an important transit country. While uncertainties with countries such as Iran, Turkmenistan and Iraq include political and technical obstacles, the TANAP pipeline initiated by the Azerbaijani government could solve technical obstacles regarding the capacity constraints of BOTAŞ's current transport system. The political issues (passing the Hydrocarbon Law of Iraq, to set clear rights and obligations for the central and Kurdish governments) are unlikely to be resolved swiftly. Nevertheless the Kurdish Regional Government (KRG) is targeting 2015/16 for the start of exporting $10 \mathrm{Bcm} / \mathrm{y}$ of natural gas (with a potential to grow up to $15 \mathrm{Bcm} / \mathrm{a}$ ) to the Turkish border.

Although it is planned that the scalable TANAP pipeline will transport just natural gas from SD2 initially, it is able to consider other alternative sources from the immediate region and beyond. This could help achieve Turkey's long-term vision to become an energy highway/bridge between east and west, which could bring more political and strategic, rather than just commercial, benefits.

The Natural Gas Market Law, which was an important step towards the liberalization of the Turkish market, was published in 2001. Since then there has been significant structural change. Before the Law entered into force, the market share of the state monopolist BOTAŞ was almost 100\%; now private companies have a market share of $20 \%$. This is paving the way for a multi-actor market structure. But during 12 years of market reforms, not all targets have been achieved and the Turkish government has been slow to implement all provisions of the Law. The main reasons for slow implementation are:

A) Absence of strong political government will to liberalize the natural gas market fully, for instance by granting BOTAŞ the right to renew the existing contracts and make new import contracts despite the contrary provisions in the Law. 

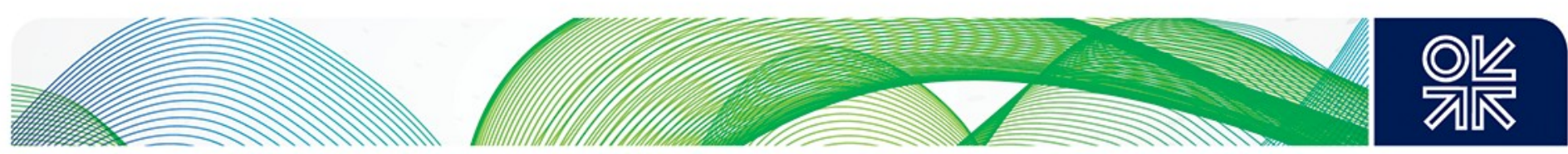

B) The government seems to use BOTAŞ subsidy mechanisms as a political tool, which is an obstacle for launching a competitive price system for the private sector.

C) The contract release system has worked very slowly - $10 \mathrm{Bcm}$ in 10 years. The more effective policy would be first to grant volume transfers to the private sector followed by the transfer of actual contracts once the share of private companies in the domestic market was sufficient.

D) BOTAŞ has not been sufficiently transparent in disclosing the necessary information on pricing, for instance, in accordance with the requirements of NGML. BOTAS has failed to live up to the advice of the Network Code to publish a balancing price at the beginning of the month. This price is supposed to factor in the offers submitted by all shippers on the market. However, at present it is still not known how BOTAS calculates prices. This said, in August and September 2013 BOTAS published the price at the beginning of the month.

There has been a successful implementation of competition in power generation and the distribution of natural gas. Some progress has been achieved after 8 years. The $20 \%$ share of private companies in the natural gas market is expected to grow in the mid- and long- run. But for this to happen the existing BOTAŞ natural gas purchase and sales agreements for pipeline gas and LNG must expire. Then private companies will be able to gain more market share.

The NGML, once fully implemented, will affect supply projections the most. It would create competition between private companies interested in bringing more natural gas to the market at competitive prices. It is increasingly attracting multinationals' interest and facilitates more efficient use of the transport system.

Furthermore, new investors, attracted by wholesale competition, are potentially emerging as importers, paving the way towards import competition. This can bring more natural gas to the market in an efficient way.

However, the government leaves the right to make exceptions concerning BOTAŞ contract releases to the decision of the Council of Ministers. This right is considered as important to 'ensure the energy security' of the country. This was the case with the signing of the $6 \mathrm{Bcm} / \mathrm{y} \mathrm{SD} 2$ contract by BOTAŞ starting in 2018. It was uncertain if the contract with Algeria for the import of $4 \mathrm{Bcm} / \mathrm{y}$ of LNG that expires in 2014 would be renewed and transferred to private companies. But in January 2013, speaking after the meeting in Algeria with the visiting Turkish Energy Minister, the Energy Minister of Algeria told reporters that Sonatrach and BOTAŞ had already decided on the conditions and terms of the new agreement starting in 2014 and lasting 10 years with the possibility of increasing the volume of gas.

Also, the government failed to fulfill the provisions of the NGML on bringing BOTAŞ's share in the market down to $20 \%$ by 2009 and to split the company (ownership unbundling) into three separate companies. For that, the government proposed on May 30, 2013 a revision of the Law, that had been under consideration since 2008. The major amendment is the provision to bring the BOTAŞ share in the domestic market down to $50 \%$ instead of $20 \%$. However the target date for the reduction is not mentioned. This makes the situation in the market uncertain and negatively affects future long-term investments in energy and the position of the private companies.

Some recommendations with regards to the NGML, and the draft revised NGML dated May 30, 2013, are summarised as following:

- The Privatisation Agency or Regulatory Agency of Turkey should take over the gas contract release tender from BOTAŞ, which is an interested party in the implementation of contract/volume release to private companies. In the power generation sector, tenders are already sucessfully organised by the Privatisation Agency. This will create a fair competition model, where the licenses to be granted to the companies would be ranked by the criterion of 

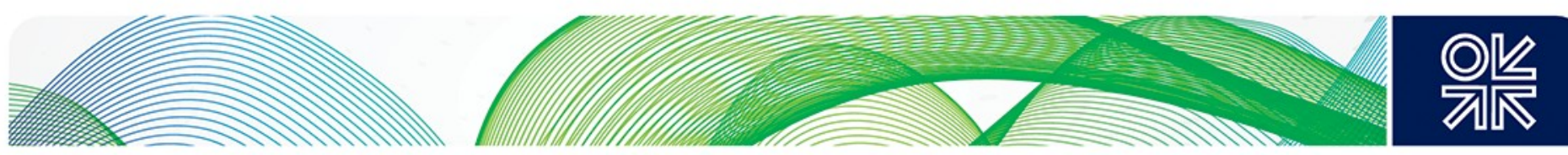

bringing the cheapest gas to the country based on a preliminary agreement with the supplier. For each released lot, BOTAŞ charges a royalty fee, which is not provided by the Law. This is another impediment to a successful privatisation of the market share.

- There is no timeframe for bringing the BOTAŞ market share down to $50 \%$ in the revised draft of the NGML. The timeframe should be included before the draft is approved.

- BOTAŞ ownership unbundling of separate wholesale, import, transport and storage companies pursuant to the Law would help to reveal the financial cost of BOTAŞ activities to private companies. In order to ensure fair competition in the liberalisation process, BOTAŞ should publicise its import, transport, and wholesale prices. As there is no account split, none of BOTAŞ activity costs can be clearly seen. BOTAŞ publishes only its balance sheet. ${ }^{46}$ But private companies need to know the BOTAŞ prices to be able to define their own prices to compete with those of BOTAŞ and attract consumers.

- The "Transit" clause should be included in the draft Law in order to regulate transit activities. In case of a hub model for Turkey, it should include a regulation enabling Turkey to import natural gas from neighbouring countries into the Turkish natural gas pool through private companies or through active involvement in production areas and re-export it to the European market.

- Apart from this, Turkey should be aiming to become an Energy Exchange centre for the region including the Middle East, the Caspian, the Eastern Mediterranean, especially having in mind that there is no such energy trade centre near Turkey. Such a hub should be able to define the right price structure based on the right market dynamics driven by supply and demand. This will not only establish a secure market for all stakeholders, but will also contribute to defining a price in the regional centre along the lines of the British NBP and other similar hubs.

This will:

a) increase the political and commercial weight of Turkey in the region;

b) bring additional revenues from taxes, employments and other sources from the energy trading activities in Turkey;

c) give Turkey an opportunity to buy natural gas at a lower price determined by supply and demand dynamics.

The higher the volume of transactions, the more market-reflective would be the resulting discoverable prices in such an Exchange Centre. This could be a key reference price for the countries in the region. Also, Turkey would be able to diversify its supply sources and have a wider pool of natural gas availability in the event of winter demand peaks.

\footnotetext{
${ }^{46}$ BOTAŞ Petroleum Pipeline Corporation Detailed Balance Sheet http://www.botas.gov.tr/icerik/eng/malidurum/bilancoGoster.asp?yil=2012
} 

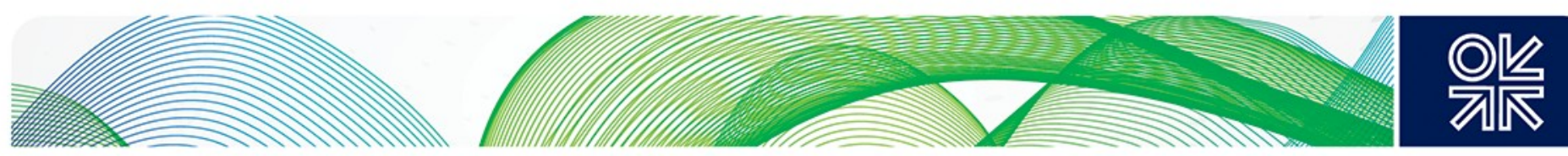

\section{Bibliography}

BOTAŞ http://www.botas.gov.tr/index.asp

* Natural Gas Sector Report 2012

* Transmission Network Operation Principles, 01/12/2007, http://www.akfelgaz.com/wpcontent/uploads/2013/05/network code 062013.pdf

* Operating Protocol

* Annual Gas Transportation by Year

* Petroleum Pipeline Corporation Detailed Balance Sheet http://www.botas.gov.tr/icerik/eng/malidurum/bilancoGoster.asp?yil=2012

* Connection Agreement (for end-users outside the license area of distribution companies) http://www.botas.gov.tr/index.asp

Deloitte (2012) Turkey's Natural Gas Market: Expectations and Developments 2012, http://www.deloitte.com/assets/Dcom-

Turkey/Local\%20Assets/Documents/turkey tr energy naturalgas 030512.pdf

\section{EMRA}

* Annual Natural Gas Market Sector Report 2011, http://www.emra.org.tr/documents/natural gas/publishments/NaturalGasMarket2011SectorReport Q9 WwGbRxxnRy.pdf

* Annual Natural Gas Market Sector Report 2012. Available in Turkish at: http://www.epdk.gov.tr/documents/dogalgaz/rapor yayin/Ddp yayin rapor 2012.pdf

* Turkish Energy Market: An Investor's Guide 2012, http://www.epdk.gov.tr/documents/strateji/rapor yayin/yatirimciel kitabi/Sgb Rapor Yayin Yatirimciel Kitabi Eng 2012 Mb3JG91tFh1B.pdf

* NGML(2001) Natural Gas Market Law, Law No.: 4646, Adoption Date: 18/4/2001, Published in the Turkish Official Gazette No. 24390 on 2 May 2001.Available at http://www.epdk.gov.tr/index.php/dogalgaz-piyasasi/mevzuat?id=50

* NGML (2001) (Law on the Article Addition), Law No.: 4918, Adoption Date: 8/7/2003. Avalaible in Turkish at: http://www.epdk.gov.tr/index.php/dogalgaz-piyasasi/mevzuat?id=50

* NGML (2001) (Law on the Amendment to NGML 4646), Law No.: 5367, Adoption Date: 16/6/2005. Avalaible in Turkish at http://www.epdk.gov.tr/index.php/dogalgaz-piyasasi/mevzuat?id=50 

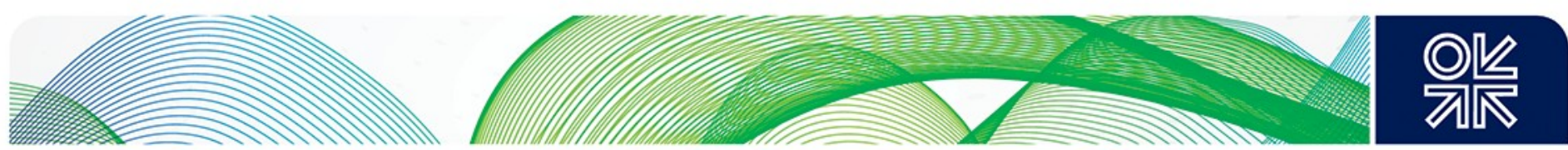

* NGML (2001) (Law on the Amendment to NGML 4646), Law No.: 5669, Adoption Date:

25/5/2007. Avalaible in Turkish at: http://www.epdk.gov.tr/index.php/dogalgaz-

piyasasi/mevzuat?id=50

* NGML (2001) (Law on the Amendment to NGML 4646), Law No.: 5784, Adoption Date:

9/7/2008. Avalaible in Turkish at: http://www.epdk.gov.tr/index.php/dogalgaz-piyasasi/mevzuat?id=50

* NGML (2001) (Law on the Amendment to NGML 4646), Law No.: 6111, Adoption Date:

13/2/2011. Avalaible in Turkish at: http://www.epdk.gov.tr/index.php/dogalgaz-

piyasasi/mevzuat?id=50

* Natural Gas Market Tariffs Regulation, (Published in the Official Gazette dated 26

September 2002, no. 24888.).http://www.ongurergan.av.tr/en-

EN/mevzuat/Natural\%20Gas\%20Market\%20Tariffs\%20Regulation.pdf

* Natural Gas Market Transmission Network Operation Regulation, (Published in the

Official Gazette no. 24918, dated 26 October 2002). Available at

http://www.petform.org.tr/images/mevzuatlar/natural gas market/7 natural gas market transmissio

$\underline{\mathrm{n} \text { network operation regulation.doc }}$

* Regulation on Service Quality in Electricity Distribution and Retail Sale, Official

Gazette Date and Number: 21/12/2012 - 28504. Available at:

http://turk.docsread.com/docs/935/index-1315.html\#26602

IEA (2012) Iraq Energy Outlook,

http://www.iea.org/publications/freepublications/publication/weoiraqexcerptsummaryWEB-1.pdf

IHS CERA European Gas Supply and Demand Tracker, March 2012.

IHS CERA Long-Term Supply and Demand Outlooks to 2035 October 2012

IHS CERA, Turkey Country Gas Report, Turkey, May 2010,

Kinnander (2010): Elin Kinnader, The Turkish-Iranian Gas Relationship: Politically Successful,

Commercially Problematic, OIES, http://www.oxfordenergy.org/wpcms/wp-

content/uploads/2010/11/NG38-TheTurkishIranianGasRelationship-ElinKinnander-2010.pdf

OECD (2012) OECD Economic Outlook No: 91, June, 2012, Medium and Long-Term Scenarios for Global Growth and Imbalances, OECD Economic Outlook, Volume 2012/1, Chapter 4,

http://www.oecd.org/berlin/50405107.pdf

PWC: Energy Deals: Merger and Acqusition Activity in Turkey's Energy Market, 2012 Annual Review, 16 January, 2013, www.pwc.com.tr/energy

Republic of Turkey Prime Ministry, Undersecretariat of State Planning Organisation, Electricity Energy Market and Supply Security Strategy Paper, 21 May 2009,

http://www.enerji.gov.tr/yayinlar raporlar EN/Arz Guvenligi Strateji Belgesi EN.pdf

Republic of Turkey Ministry of Energy and Natural Resources, Strategic Plan 2010-2014, http://www.enerji.gov.tr/yayinlar raporlar EN/ETKB 20102014 Stratejik Plani EN.pdf 

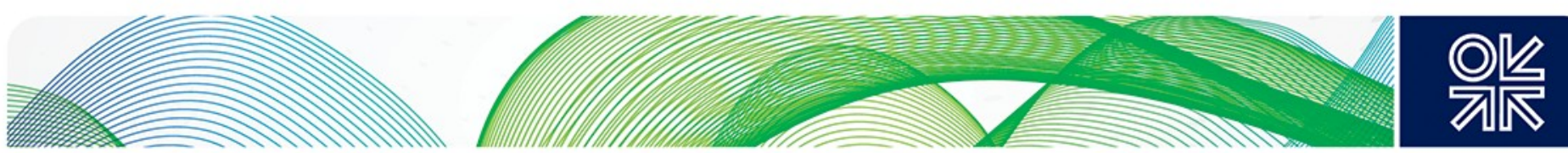

MENR Activity Report 2012. Available in Turkish at:

http://www.enerji.gov.tr/yayinlar raporlar/2012 faaliyet raporu.pdf

Sanli-Nikaz (2013): Barış Sanlı, Nadim Ekiz, Türkiye'nin Doğalgaz Arz Güvenliği'nin Analitik Bir

Değerlendirmesi (An Analytical Evaluation of Natural Gas Supply Security of Turkey),

http://www.barissanli.com/calismalar/2013/bsanli-nekiz dogalgaz arz guvenligi-May2013.pdf

Turkish Natural Gas Market, PETFORM (Petrolium Platform Assosiation),

http://www.petform.org.tr/?lang=en\&a=3\&s=1

World Bank, Turkey: Gas Strategy, May 2007

Turkish Petroleum Corporation General Directorate, 2009 Oil and Natural Gas Sector Report, http://www.enerji.gov.tr/yayinlar raporlar EN/Sektor Raporu TPAO 2009 en.pdf

TEIAS Turkish Electricity Generation Plan,http://www.teias.gov.tr/Eng/GenerationPlan.aspx

Turkey Oil \& Gas Report Q2 2008, Business Monitor International LTD

Turkey Oil \& Gas Report Q2 2009, Business Monitor International LTD

Turkey Oil \& Gas Report Q2 2010, Business Monitor International LTD

Turkey Oil \& Gas Report Q2 2011, Business Monitor International LTD

Turkey Oil \& Gas Report Q2 2012, Business Monitor International LTD

Wood Mackenzie Iraq Gas Export Potential Report, March 2011

World Bank Commodity Price Data,

http://siteresources.worldbank.org/INTPROSPECTS/Resources/334934-1111002388669/8293921357588777389/Pnk 0713.pdf

World Nuclear Association (2013): Nuclear Power in Turkey (Updated October 2013), World Nuclear Association, http://world-nuclear.org/info/Country-Profiles/Countries-T-

Z/Turkey/\#.UnTvuFPkWrO 